\title{
PARÂMETROS DE CRESCIMENTO E MARCHA DE ABSORÇÃO DE NUTRIENTES NA PRODUÇÃO DE MINITUBÉRCULOS DE BATATA cv. ATLANTIC
}

\author{
Patrícia Favoretto
}

\begin{abstract}
Dissertação apresentada à Escola Superior de Agricultura "Luiz de Queiroz", Universidade de São Paulo, para obtenção do título de Mestre em Agronomia, Área de Concentração: Fitotecnia.
\end{abstract}

P I R A C I C A B A

Estado de São Paulo - Brasil

Março - 2005 


\title{
PARÂMETROS DE CRESCIMENTO E MARCHA DE ABSORÇÃO DE NUTRIENTES NA PRODUÇÃO DE MINITUBÉRCULOS DE BATATA cv. ATLANTIC
}

\author{
Patrícia FAVORETTo \\ Engenheiro Agrônomo
}

Orientador: Prof. Dr. PAUlo CÉSAR TAVARES DE MELO

\begin{abstract}
Dissertação apresentada à Escola Superior de Agricultura "Luiz de Queiroz", Universidade de São Paulo, para obtenção do título de Mestre em Agronomia, Área de Concentração: Fitotecnia.
\end{abstract}

P I R A C I C A B A

Estado de São Paulo - Brasil

Março - 2005 
Dados Internacionais de Catalogação na Publicação (CIP) DIVISÃO DE BIBLIOTECA E DOCUMENTAÇÃO - ESALQ/USP

\section{Favoretto, Patrícia}

Parâmetros de crescimento e marcha de absorção de nutrientes na produção de minitubérculos de batata cv. Atlantic / Patrícia Favoretto. - - Piracicaba, 2005.

98 p. : il.

Dissertação (mestrado) - - Escola Superior de Agricultura Luiz de Queiroz, 2005.

Bibliografia.

1. Absorção de nutriente 2. Batata - Semente 3. Crescimento vegetal 4. Hidroponia 5. Muda 6. Tubérculo il. Título

CDD 633.491

"Permitida a cópia total ou parcial deste documento, desde que citada a fonte - $\mathrm{O}$ autor" 
A Deus acima de tudo,

AGRADEÇO

À minha mãe Cida e ao meu pai Dinho pelo incentivo e confiança, fornecendo-me forças para atingir meus objetivos, com todo o meu amor

DEDICO.

Aos meus irmãos Nenê, Tatinha e minha Grei, aos meus cunhados Poliana e

Luis Antonio e aos "meus anjos" Mazoca, Biba, Pê, Lulu, Ví, Pepe, Má e Antonio pelo carinho, amizade e fonte de alegria e de esperança

OFEREÇO. 


\section{AGRADECI MENTOS}

Ao Prof. Dr. Paulo César Tavares de Melo pela confiança e orientação. Por toda compreensão durante a realização desse trabalho.

Ao Prof. Dr. Quirino Augusto de Camargo Carmello, por todo auxílio e atenção. Por disponibilizar o Laboratório de Nutrição Mineral de Plantas para realização das análises químicas.

À Coordenação do Programa de Pós-Graduação em Fitotecnia.

Ao Eng ${ }^{\circ}$ Agr $^{\circ}$ Pedro Candido Rytsi Hayashi, "Pedrinho", pela amizade inestimável e por transmitir valiosos conhecimentos e apoio imprescindível para realização deste trabalho.

À pesquisadora e "anjo" Dra. Maria do Carmo de Salvo Soares Novo pelo amor e dedicação.

À Dra. Gláucia Regina Anti pela "baita" paciência e colaboração na realização desse trabalho e com quem tive o prazer enorme de conviver e aprender.

À Eng ${ }^{\circ}$. Agr ${ }^{\circ}$. MSc Eliane Gomes Fabri pelo apoio e carinho fundamentais nos momentos mais decisivos e pela grande amizade.

À Dra. Maria Cristina Stolf Nogueira, à Dra. Gláucia Bovi Ambrosano, e, em especial, ao Prof. Dr. Décio Barbin, pelos ensinamentos e sugestões nas análises estatísticas.

À Dra. Mônica Abreu do IAC, pela atenção e análise química dos substratos.

À secretária da Pós Graduação da Fitotecnia Luciane Aparecida Lopes Toledo por todo auxílio e atenção, bem como amizade e agradável convívio.

Às funcionárias: "Betoca", D. Helena e Célia pelo carinho e atenção.

Às funcionárias Ednéia C. S. Mondoni, Lúcia H. S. P. Forti, Lurdes A. D. de González, Nivanda M. de M. Ruiz e Sueli M. A. Bovi pelo apoio técnico bem como a amizade construída.

Aos funcionários da estufa Elaine, Ligia e Leandro pela eficiência e dedicação.

Aos amigos da "salinha" Fernando, Fernanda e Heleninha pela amizade e compreensão.

A todos aqueles que direta e indiretamente colaboraram na realização do meu trabalho. "Deus nos disse: Junte-se aos bons". Foi por isso que eu consegui realizar esse trabalho. 


\section{SUMÁRIO}

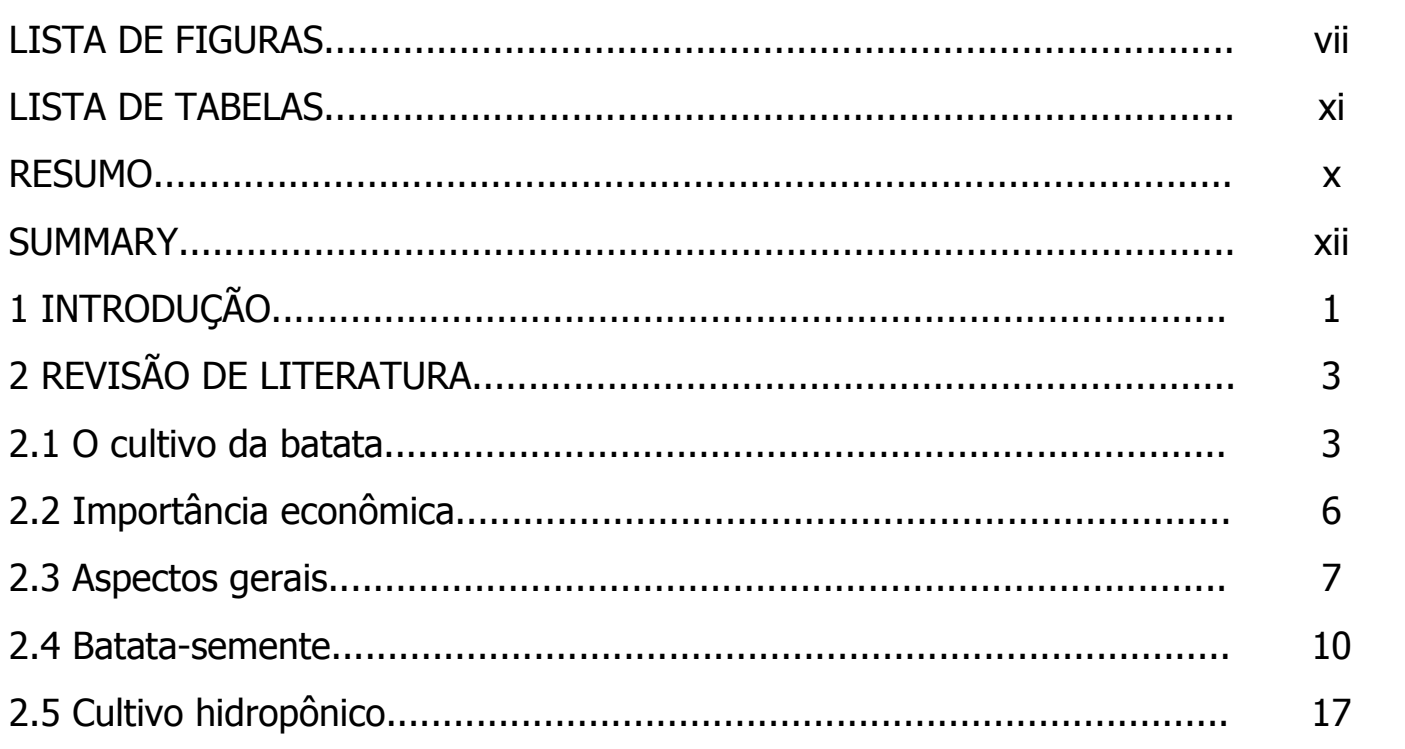

2.6. Parâmetros de crescimento e absorção de nutrientes........................ 23

3 MATERIAL E MÉTODOS......................................................... 28

3.1 Localização e características gerais........................................... 28

3.2 Características dos substratos..................................................... $\quad 30$

3.3 Solução nutritiva.................................................................... 31

3.4 Características do cultivar........................................................ 32

3.5 Transplantio e condução das mudas............................................ 33

3.6 Avaliação e coletas das plantas.................................................. 34

3.7 Preparo das amostras...................................................... 35

3.8 Análise química das plantas.................................................. 36

3.9 Delineamento experimental............................................... 36

3.10 Controle fitossanitário...................................................... 37 
4 RESULTADOS E DISCUSSÃO.................................................... 38

4.1 Parâmetros de crescimento..................................................... 38

4.1.1 Altura das plantas............................................................. 38

4.1.2 Número de hastes.............................................................. 39

4.1 .3 Número de folhas.............................................................. 40

4.1.4 Número de minitubérculos....................................................... 42

4.1.5 Diâmetro e peso do material fresco dos minitubérculos................... 43

4.1.6 Peso do material seco........................................................... 46

4.2 Marcha de absorção de macronutrientes......................................... 51

4.2 .1 Nitrogênio.................................................................... 51

4.2.2 Fósforo....................................................................... 54

4.2.3 Potássio.......................................................................... 5

4.2.4 Cálcio...................................................................... 59

4.2 .5 Magnésio......................................................................... 62

4.2.6 Enxofre.................................................................... 64

4.3 Marcha de absorção de micronutrientes...................................... 66

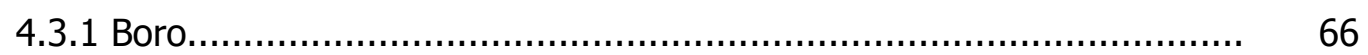

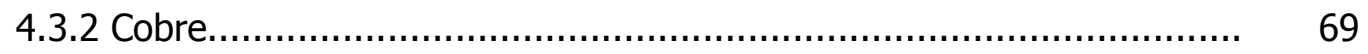

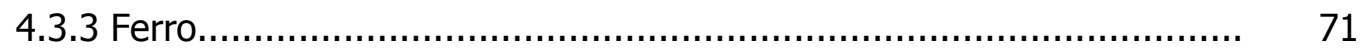

4.3.4 Manganês............................................................................ 72

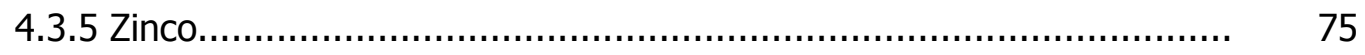

4.4 Considerações finais...................................................................... 79

5 CONCLUSÕES.................................................................... 81

REFERÊNCIAS BIBLIOGRÁFICAS.............................................. 82 


\section{LISTA DE FIGURAS}

Página

1 Sistema de irrigação nos canteiros onde foram cultivados os minitubérculos..................................................................... 29

2 Plantas em pleno estádio de desenvolvimento (32 DAT)...................... 30

3 Plantas matrizes em bandejas de produção de mudas (7 DAT)............. 34

4 Altura das plantas obtida para os tratamentos $(\mathrm{cm})$......................... 39

5 Número de hastes por planta para os tratamentos $\left(n^{\circ}\right.$ planta $\left.^{-1}\right) \ldots \ldots \ldots \ldots . . . . . .40$

6 Número de folhas por planta obtido nos tratamentos.......................... 41

7 Número de minitubérculos produzidos por planta para os tratamentos.... 43

8 Diâmetro dos minitubérculos por planta para os tratamentos................. 44

9 Peso do material fresco nos minitubérculos por planta para os

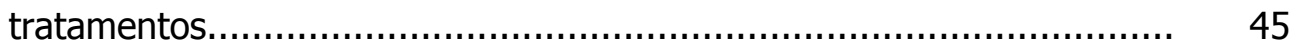

10 Peso do material seco na parte aérea ( $\mathrm{g}$ planta ${ }^{-1}$ ) para os tratamentos............................................................................ 47

11 Peso do material seco $(\mathrm{g})$ nos minitubérculos produzidos por planta para os tratamentos................................................................ 48

12 Peso do material seco total por planta (g) para os tratamentos............. 49

13 Nitrogênio acumulado na parte aérea para os tratamentos

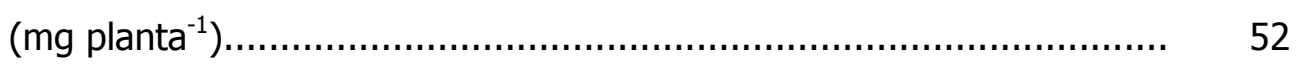

14 Nitrogênio acumulado nos minitubérculos para os tratamentos

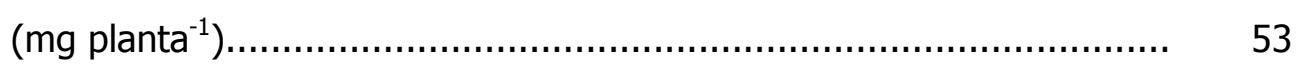

15 Fósforo acumulado na parte aérea para os tratamentos

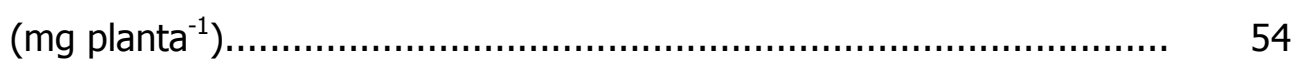

16 Fósforo acumulado nas raízes para os tratamentos (mg planta $\left.{ }^{-1}\right) \ldots \ldots \ldots . . \quad 55$ 
17 Fósforo acumulado nos minitubérculos para os tratamentos

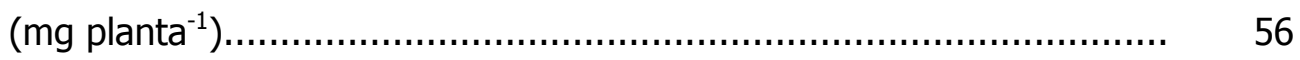

18 Potássio acumulado na parte aérea para os tratamentos

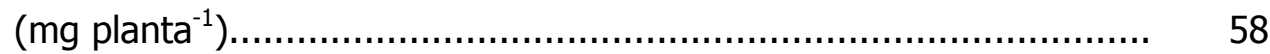

19 Cálcio acumulado na parte aérea para os tratamentos

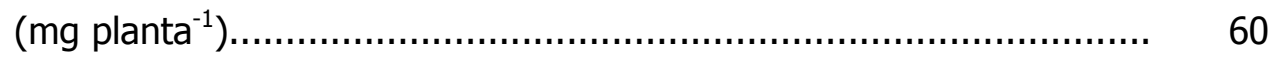

20 Cálcio acumulado nas raízes das para os tratamentos (mg planta $\left.{ }^{-1}\right) \ldots \ldots .61$

21 Magnésio acumulado na parte aérea para os tratamentos

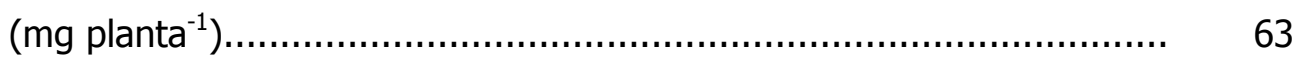

22 Enxofre acumulado na parte aérea para os tratamentos ( $\mathrm{mg} \mathrm{planta}^{-1}$ )... 65

23 Boro acumulado na parte aérea para os tratamentos ( $\left.\mu \mathrm{g}^{\text {planta }}{ }^{-1}\right) \ldots \ldots . . .67$

24 Boro acumulado nos minitubérculos para os tratamentos ( $\mu \mathrm{g}$ planta $\left.{ }^{-1}\right) . . \quad 68$

25 Cobre acumulado nos minitubérculos para os tratamentos ( $\mu \mathrm{g} \mathrm{planta}^{-1}$ ). $\quad 70$

26 Ferro acumulado na parte aérea para os tratamentos $\left(\mu \mathrm{g}\right.$ planta $\left.^{-1}\right) \ldots \ldots . \quad 71$

27 Manganês acumulado na parte aérea para os tratamentos ( $\mu$ g planta $^{-1}$ ).. 73

28 Manganês acumulado nos minitubérculos para os tratamentos

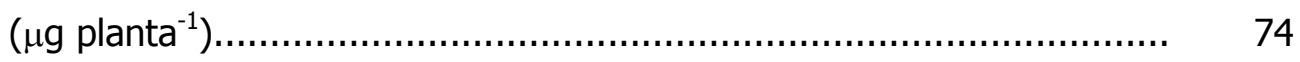

29 Zinco acumulado na parte aérea para os tratamentos ( $\left.\mu \mathrm{g} \mathrm{planta}^{-1}\right) \ldots \ldots . \quad 75$

30 Zinco acumulado nas raízes para os tratamentos $\left(\mu \mathrm{g}\right.$ planta $\left.{ }^{-1}\right) \ldots \ldots \ldots \ldots . . . . . . \quad 76$

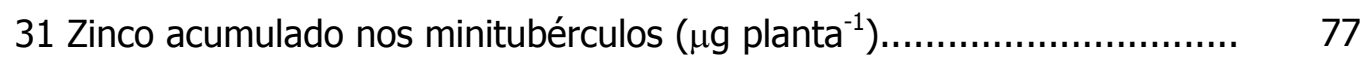




\section{LISTA DE TABELAS}

Página

1 Composição química aproximada da batata..................................... 8

2 Teores aproximados dos principais minerais na batata em peso seco...... 9

3 Valores médios das temperaturas (interna e externa) máxima e mínima mensal durante o período do experimento em Vargem Grande do Sul -

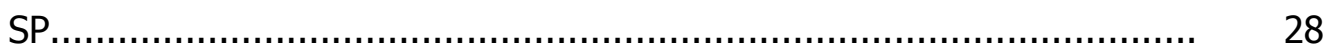

4 Características físicas e químicas dos substratos utilizados.................... 31

5 Composição da solução nutritiva utilizada no experimento.................... 31 


\title{
PARÂMETROS DE CRESCI MENTO E MARCHA DE ABSORÇÃO DE NUTRIENTES NA PRODUÇÃO DE MI NI TUBÉRCULOS DE BATATA cV. ATLANTIC
}

\author{
Autora: PATRÍCIA FAVORETTO \\ Orientador: PAULO CÉSAR TAVARES DE MELO
}

\section{RESUMO}

Por ser a cultura anual de maior importância econômica no Brasil e apresentar custo elevado de produção, novas alternativas vêm sendo adotadas para diminuir os custos e obter batata-semente de boa qualidade. Com o objetivo de determinar os parâmetros de crescimento e a marcha de absorção de nutrientes a partir de plântulas do cv. Atlantic, para a produção de minitubérculos em sistema hidropônico, realizou-se esse trabalho no período de setembro a novembro de 2004 em Vargem Grande do Sul - SP, localizada na altitude $21^{\circ} 47^{\prime} 28^{\prime \prime S}$ e na longitude $046^{\circ} 53^{\prime} 04^{\prime \prime} \mathrm{W}$ com $938 \mathrm{~m}$ de altitude. O delineamento experimental foi inteiramente casualizado, com sete tratamentos e quatro repetições. As plantas foram avaliadas e coletadas em intervalos semanais do início do desenvolvimento até a fase da colheita aos 53 dias após transplantio (DAT). As plantas coletadas foram separadas em sistema radicular, parte aérea e minitubérculos, secadas em estufa e pesadas em balança analítica para obtenção de peso do material seco. Após secagem foram moídas em moinho e submetidas à análise para obtenção da extração de nutrientes para os tratamentos. Os resultados obtidos indicam que o acúmulo dos nutrientes é influenciado pelas fases da cultura e peso do material seco total das plantas. A seqüência do acúmulo máximo dos 
macronutrientes para os tratamentos foi: $\mathrm{K}>\mathrm{N}>\mathrm{Ca}>\mathrm{P}>\mathrm{Mg}>\mathrm{S}$ e para os micronutrientes foi: $\mathrm{Fe}>\mathrm{Mn}>\mathrm{B}>\mathrm{Zn}>\mathrm{Cu}$. A seqüência de exportação dos macronuteintes foi: $\mathrm{K}>\mathrm{N}>\mathrm{P}>\mathrm{S}>\mathrm{Mg}>\mathrm{Ca}$ e para os micronutrientes foi: $\mathrm{Fe}>\mathrm{Zn}>$ $\mathrm{Cu}>\mathrm{B}>\mathrm{Mn}$. O sistema hidropônico permitiu disponibilizar os nutrientes mais prontamente assimiláveis pelas plantas e conseqüentemente maiores taxas de multiplicação. 


\title{
GROWTH PARAMETERS AND UPTAKE RATE I N POTATO CV. ATLANTIC MI NITUBER PRODUCTION
}

\author{
Author: PATRÍCIA FAVORETTO \\ Adviser: PAULO CÉSAR TAVARES DE MELO
}

\section{SUMMARY}

As potato is the most important economic annual staple crop in Brazil and its production involves high costs, new alternatives are being adopted to decrease costs and obtain high quality potato seed. This study aimed at determining the growth parameters and the uptake rate by seedling from cv. Atlantic to be used for minituber production in a hydroponic system. It was carried out from setember to november 2004 in Vargem Grande do Sul - SP, located in latitude $21^{\circ} 47^{\prime} 28^{\prime \prime S}$ and longitude $046^{\circ} 53^{\prime} 04^{\prime \prime} \mathrm{W}$ at altitude $938 \mathrm{~m}$. The experimental design was randomized blocks with seven treatments and four replications. The plants were collected and evaluated at weekly intervals from the initial development phase throughout harvesting phase, 53 days after transplanting (DAT). The plants were separated into root system, aerial part and minituber, dried in oven and weighed on an analytical scale in order to obtain the dry mass weight. After drying, the plants were grounded in a mill and submitted to analysis in order to obtain the nutrient extraction for each treatment. The results showed that the nutrient accumulation is influenced by the phase of the crop and the total dry mass weight of plants. The sequence of maximum macronutrient accumulation 
for the treatments was: $\mathrm{K}>\mathrm{N}>\mathrm{Ca}>\mathrm{P}>\mathrm{Mg}>\mathrm{S}$, and for the micronutrient it was: Fe $>\mathrm{Mn}>\mathrm{B}>\mathrm{Zn}>\mathrm{Cu}$. The sequence of macronutrient exportation was: $\mathrm{K}>\mathrm{N}>\mathrm{P}>\mathrm{S}$ $>\mathrm{Mg}>\mathrm{Ca}$, and for the micronutrients it was: $\mathrm{Fe}>\mathrm{Zn}>\mathrm{Cu}>\mathrm{B}>\mathrm{Mn}$. The hydroponic system allowed to make the nutrients more readly available to the plants, and, as a consequence, higher rates of multiplcation were observed. 


\section{I NTRODUÇÃO}

A batata, Solanum tuberosum L., é considerada a olerácea mais importante no Brasil e no mundo. Nos últimos anos tem ocorrido um incremento em sua produção, decorrente da melhoria do material de propagação e da incorporação de novas fronteiras de produção, permitindo o melhor aproveitamento dos insumos modernos e assim contribuindo para o aumento da produtividade por área.

A utilização de sementes de alto padrão genético e fitossanitário são fundamentais para a exploração comercial da batata. A semente representa de $30 \%$ a $40 \%$ do custo de produção, refletindo diretamente na produtividade e na qualidade dos tubérculos.

No Brasil, a produção de batata-semente constitui-se uma das fases mais importantes da cadeia produtiva da batata, tendo mostrado importante melhoria. Os sistemas de produção utilizados têm experimentado notáveis avanços, destacando-se o emprego de técnicas da biotecnologia, como a cultura de tecidos, para a produção de batata-semente. Resultados práticos importantes vêm sendo obtidos pelo uso de cultura de meristemas na eliminação de viroses e multiplicação rápida in vitro, como a micropropagação de plântulas sadias. Entretanto, a falta de informação na aérea de nutrição mineral de plantas é um fator limitante para que $\mathrm{o}$ binômio produtividade $\mathrm{x}$ qualidade de propágulos seja atingido.

De outro lado, os sistemas tradicionais de produção de sementes pré-básicas utilizados no nosso país apresentam, como característica comum, a reduzida eficiência em razão dos baixos índices de multiplicação de tubérculos. São produzidos em média, de três a cinco tubérculos por planta (Daniels et al., 2000a), o que contribui para a elevação dos custos da semente. Por conta disso, a produção de minitubérculos de batata em cultivo protegido vem se desenvolvendo e, hoje, abastece várias áreas 
produtoras de batata-semente, tornando o Brasil capaz de atender uma parte deste mercado com material propagativo de boa qualidade.

A produção brasileira de batata depende de cultivares importados e os mais utilizados na atualidade são: Atlantic, Ágata, Asterix, Cupido, Monalisa e Mondial. A importação de batata-semente de países como Holanda, Alemanha e Canadá, sempre foi uma necessidade, pois nas condições ambientais do país o material perde suas qualidades diminuindo o seu rendimento.

Entre os cultivares disponíveis no mercado, a Atlantic destaca-se e responde por cerca de $80 \%$ do mercado nacional formal de batata do tipo chips, por ser uma das poucos cultivares adaptada a essa finalidade e, por apresentar alta percentagem de matéria seca, conferindo-Ihe um maior rendimento. No entanto, as peculiaridades de cada cultivar fazem uma grande diferença na produtividade, visto que, os estudos existentes sobre a nutrição mineral da cultura são voltados para cultivares de consumo in natura, enquanto que, às cultivares para fins industriais, nas condições tropicais, as pesquisas são quase inexistentes.

A cultura da batata apresenta ciclo curto, que é ainda mais reduzido quando se trata de produção de batata-semente. Assim, o conhecimento sobre a nutrição e o comportamento durante o crescimento e o desenvolvimento da cultura em certos ambientes de cultivo é de suma importância, para que se possa disponibilizar nutrientes de forma prontamente assimiláveis a fim de atingir sua máxima capacidade produtiva.

Baseado nessas considerações, o presente trabalho teve como objetivos, determinar os parâmetros de crescimento e a marcha de absorção de nutrientes a partir de mudas, cv. Atlantic, para a produção de minitubérculos de batata-semente, em sistema hidropônico. 


\section{REVISÃO DE LITERATURA}

\subsection{0 cultivo da batata}

A batata teve como centro de origem a vizinhança do lago Titicaca, próximo à fronteira entre Peru e Bolívia. Nos Andes, a bataticultura tem sido praticada pelos indígenas, nos últimos oito milênios, havendo oito espécies botânicas cultivadas e mais de 200 espécies tuberíferas silvestres. Introduzida na Europa no século XVI pelos conquistadores espanhóis, é hoje um dos produtos alimentares mais difundidos em todo o mundo. Disseminada pela maioria das regiões tropicais e subtropicais do planeta, converteu-se, na atualidade, na base da alimentação de muitos povos. A batata é a quarta fonte alimentar da humanidade, logo após o arroz, o trigo e o milho (Filgueira, 2003).

A batata é uma solanácea anual, que apresenta caules aéreos, herbáceos, e suas raízes originam-se na base desses caules ou hastes. 0 sistema radicular é delicado e superficial, com raízes concentrando-se até $30 \mathrm{~cm}$ de profundidade. Suas folhas são compostas por folíolos arredondados e as flores hermafroditas apresentam-se reunidas em inflorescências no topo da planta (Filgueira, 2000). A parte aérea é herbácea, com altura variável entre 50 e $70 \mathrm{~cm}$, podendo, entretanto, alcançar até 1,5 m na fase adulta. $O$ ciclo vegetativo da cultura pode ser precoce ( $<90$ dias), médio ( $90-110$ dias) ou longo (> 110 dias), dependendo da cultivar (Fortes \& Pereira, 2003).

O cultivo se caracteriza pelo uso de cultivares europeus, emprego de batatasemente de baixa qualidade, utilização de grande quantidade de fertilizantes e produtos fitossanitários, alto custo de produção, sazonalidade de preços e de produção, além de baixa produtividade (Souza et al., 1999).

De acordo com Miranda Filho et al. (2003), as condições climáticas brasileiras permitem plantar e colher batata todos os meses do ano, numa escala sucessiva de 
safras. Dependendo do clima de cada região de cultivo, podem ser realizadas em três safras distintas: safra das águas (plantio de agosto a novembro); da seca (plantio de janeiro a março) e safra de inverno (plantio de maio a julho).

Os tubérculos colhidos do plantio de inverno são de alta qualidade e, teve tanto êxito na bataticultura paulista, que sua colheita corresponde a uma época de preços baixos no mercado. O pacote tecnológico para a produção no inverno é superior ao da produção da época das águas, contribuindo para a produtividade média ser mais elevada. A expansão na safra de inverno nos últimos anos tem sido determinante para influenciar o comportamento dos preços da safra das águas (Miranda Filho et al., 2003).

A safra das águas representa um pouco mais de $50 \%$ da produção total brasileira e normalmente é conduzida em regiões de maiores altitudes nos Estados de Minas Gerais e São Paulo e, ainda no Sul do país, buscando sempre condições de temperaturas mais amenas (Antunes \& Fortes, 1981).

A temperatura média ideal para a cultura da batata está entre 10 e $20^{\circ} \mathrm{C}$, sendo que a maioria dos cultivares comerciais tuberizam melhor com temperaturas médias pouco acima de $15^{\circ} \mathrm{C}$ (Antunes \& Fortes, 1981). Entretanto, a maior parte das cultivares plantadas atualmente no país foram desenvolvidas especificamente para regiões temperadas e, quando submetidas ao clima tropical, apresentam produtividade muito aquém do seu potencial (Miranda et al., 2003).

A temperatura pode afetar diretamente a planta de batata ou pode interagir com outros fatores ambientais para modificar o seu comportamento. Regiões que apresentam temperaturas máximas entre $20^{\circ}$ e $30^{\circ} \mathrm{C}$ e mínimas entre $8^{\circ}$ e $15^{\circ} \mathrm{C}$ são mais favoráveis ao cultivo do que regiões com pouca amplitude térmica, sendo que a temperatura ótima para a fotossíntese está em torno de $20^{\circ} \mathrm{C}$. O estresse térmico pode diminuir os fotoassimilados disponíveis ao desenvolvimento da planta, e também sua participação aos tubérculos. As altas temperaturas, características de regiões tropicais e subtropicais, causam severo decréscimo na produção de tubérculos e são consideradas os maiores impedimentos ambientais para a produção e disseminação de batata nessas regiões (Burton, 1981). Além da queda do rendimento, há aumento na ocorrência do 
distúrbio fisiológico embonecamento e redução da matéria seca dos tubérculos (Hugles, 1974; Marinus \& Bodlaender, 1975).

A temperatura tem influência marcante no crescimento da planta de batata. Temperaturas altas estimulam a produção de folhagem, enquanto que as temperaturas mais baixas favorecem o crescimento do tubérculo. Por conseguinte, a temperatura, de alguma forma, incide sobre a distribuição da matéria seca formada (Zaag, 1993). Temperaturas (noturnas e diurnas) e luminosidade são fatores climáticos essenciais à produção de batata. Assim, temperaturas superiores a $25^{\circ}-30^{\circ} \mathrm{C}$ reduzem o potencial produtivo da maioria dos cultivares (Miranda Filho et al., 2003).

Na presença de alta intensidade de luz, a assimilação é mais elevada do que no caso de uma intensidade luminosa reduzida. Quando a intensidade da luz aumenta, a temperatura ótima para a assimilação também se torna ligeiramente mais alta. Portanto, as zonas muito ensolaradas são mais favoráveis do que as regiões freqüentemente nubladas. A presença de muita luz modifica a relação folhagem/crescimento do tubérculo em favor do crescimento do mesmo. Isso explica a razão porque é possível obter rendimentos muito altos em cultivos situados a grandes alturas em regiões tropicais e subtropicais, onde a intensidade da luz é elevada, mesmo com as temperaturas diurnas bastante altas, e com temperaturas baixas durante 0 período noturno (Zaag, 1993).

É interessante destacar que os clones introduzidos pelos espanhóis na Europa estavam adaptados a desenvolver tubérculos sob condições de dias curtos, de 12 horas, na região dos Andes, e não sob dias longos de 16 - 18 horas, como ocorrem no continente europeu (Hawkes, 1993). Evidências encontradas nos arquivos espanhóis mostram claramente que as primeiras batatas européias eram adaptadas a fotoperíodo curto, com a tuberização ocorrendo de dezembro a janeiro, em regiões aparentemente livres de geadas no sul da Espanha e na Itália (Hawkes \& Francisco-Ortega, 1992).

No Brasil, temperaturas acima das ideais são freqüentemente observadas durante o cultivo da batata nas safras das águas e da seca, principalmente nos plantios realizados nos estados de Minas Gerais e São Paulo. Também é relativamente comum a ocorrência de temperaturas noturnas mais elevadas, o que aumenta a respiração com conseqüente redução na produção (Pinto, 1999). No nosso país, a cultura apresenta 
maiores níveis de produtividade e melhor qualidade dos tubérculos durante o inverno seco, sob irrigação (Furomoto, 1997).

As exigências climáticas da cultura são peculiares e precisas, ressaltando-se que o fator limitante é a temperatura elevada, especialmente a temperatura noturna, pois quando ela se mantém acima de $20^{\circ} \mathrm{C}$ durante 60 noites ou mais, não ocorre a tuberização (Ewing, 1997). O plantio da cultura da batata deve ser realizado preferencialmente no período de inverno e ou em regiões que apresentem alta altitude para compensar os efeitos causados por altas temperaturas. As maiores produtividades são obtidas nos países onde os dias duram de 13 a 17 horas na época de tuberização com temperaturas médias entre 15 e $18^{\circ}$ e com irrigação (Haeder \& Beringer, 1983).

\subsection{I mportância econômica}

A América Latina produz aproximadamente 8.000 .000 de toneladas de batata atualmente, sendo que 2,5 milhões de toneladas são produzidas pelo Brasil. A batata é a hortaliça mais plantada no Brasil, com grande expressão econômica em diversos Estados. O contínuo aumento da produção é uma resposta frente à forte demanda de batata para consumo in natura e processada. Convém considerar que a globalização da economia tem criado uma homogeneização do consumo de alguns produtos, que entre suas características combinem praticidade, qualidade e rapidez, sendo a batata um dos produtos mais aptos para esse fim (Andreu, 2003).

A tendência mundial é a de aumentar a média anual da porcentagem de consumo de produtos pré-fritos e congelados, o que significa um crescimento importante no mercado industrial nos últimos anos e uma previsão de aumento ainda maior para o futuro. A demanda mundial tem mostrado crescimento de $13 \%$ nos últimos anos, sendo que entre os países do Mercosul, a Argentina destaca-se com 63\% de aumento do consumo desses produtos (Andreu, 2003).

A produção mundial de batata é de 310 milhões de toneladas cultivadas em 19 millhões de hectares por ano, com um rendimento médio de 16,3 toneladas por hectare. Enquanto que, o Brasil produz, aproximadamente, dois milhões de toneladas cultivadas em 100 mil hectares. Com relação às importações, aproximadamente 100 mil toneladas de batata processadas são comercializadas no Brasil anualmente (ABBA, 
2004). O mercado brasileiro, no aspecto do consumo, assemelha-se ao mercado mundial. O consumo aparente em 2002, deve ter se aproximado de 2,9 milhões de toneladas, mesma quantidade, por exemplo, de 1998 e 1999 (FNP, 2004).

Na região Sul do país, colhe-se aproximadamente 1,2 milhão de toneladas por ano, que correspondem cerca de $50 \%$ da produção do país. Porém, nos últimos anos, houve crescimento considerável da produção nas regiões Centro-Oeste e Sudeste, em particular no estado de Minas Gerais, passando de terceiro para o primeiro produtor nacional, ocupando o lugar do estado do Paraná. A produção anual de batata-semente no Sul se destaca, por corresponder a $50 \%$ da produção do país, com aproximadamente 40 mil toneladas. A cadeia produtiva envolve considerável volume de recursos e significativa mão-de-obra, estimando-se que 25 mil famílias ocupam-se diretamente na produção (Pereira \& Daniels, 2003).

Em relação ao custo de produção da cultura, os principais componentes são: sementes (35\%), fertilizantes (15\%), defensivos (15\%) e mão-de-obra (10\%). Dentre estes, os fertilizantes apresentam especial importância pois, além de influenciar na qualidade e custo de produção para mercado e indústria, também influenciam na qualidade e custo da semente produzida (Embrapa Hortaliças, 1999). Neste cenário a preocupação em conseguir aperfeiçoar a qualidade fitossanitária e reduzir os custos dessa produção é uma preocupação constante dos pesquisadores.

A aquisição de batata-semente, fertilizantes e defensivos, na bataticultura representa aproximadamente 65 a $85 \%$ do custo final (Camargo Filho, 2001). A produção de hortaliças, no Brasil, é por natureza, intensiva em mão-de-obra, contribuindo significativamente para a geração de emprego no campo. Só a cultura da batata, emprega mais de 600 mil pessoas, gerando, ainda, um PIB superior a 1,3 bilhões de dólares. A região do Sudoeste se destaca pela batata de alta qualidade que produz, fruto de alto nível tecnológico e principalmente muita dedicação (Vieira, 2001).

\subsection{Aspectos gerais}

A batata é um dos poucos alimentos capazes de nutrir a crescente população mundial, não apenas como alimento energético, mas também como fonte de proteínas, vitaminas e minerais. Tem proteína de boa qualidade e índice de valor biológico alto. $\mathrm{A}$ 
relação entre proteínas e calorias disponíveis indica que a batata poderá ser uma das melhores alternativas alimentares para os povos dos países subdesenvolvidos ou em desenvolvimento. A composição química da batata está indicada na Tabela 1 (Smith, 1977).

Tabela 1. Composição química aproximada da batata

\begin{tabular}{lcc}
\hline Componentes & Média (\%) & Variação (\%) \\
\hline Umidade & 77,5 & $63,2-86,9$ \\
Sólidos totais & 22,5 & $13,1-36,8$ \\
Carboidratos totais & 19,4 & $13,3-30,5$ \\
Proteínas & 2,0 & $0,7-4,6$ \\
Cinzas & 1,0 & $0,44-1,9$ \\
Fibras & 0,6 & $0,17-3,48$ \\
Lipídios & 0,1 & $0,02-1,0$ \\
\hline
\end{tabular}

A matéria seca (MS) ou sólidos totais, corresponde a todo material que faz parte do tubérculo após a remoção da água. A quantidade de MS nos tubérculos influencia diretamente na qualidade do produto processado. Dos carboidratos, o amido é o que se apresenta em maior teor nos tubérculos, correspondendo de 65 a $80 \%$ do peso seco que contém, ainda, cerca de 0,09\% de fósforo (Pereira, 1987).

Reconhecida como um dos alimentos mais completos, além de proporcionar energia oriunda dos carboidratos, em sua composição uma batata de $150 \mathrm{~g}$ apresenta um valor calórico de $150 \mathrm{cal}$, contem 3,7 g de proteínas, $0 \mathrm{~g}$ de lipídeos, $23 \mathrm{~g}$ de carboidratos, $27 \mathrm{~g}$ de fibras, $5 \mathrm{mg}$ de sódio e, rica em potássio, contendo $729 \mathrm{mg}$ deste nutriente (ABBA, 2004). Os compostos inorgânicos ou minerais presentes na batata variam muito de acordo a variedade, tratos culturais, clima, local de plantio, maturação e armazenamento, sendo apresentados na Tabela 2 (Smith, 1977). 
Tabela 2. Teores aproximados dos principais minerais na batata em peso seco

\begin{tabular}{lccc}
\hline \multicolumn{1}{c}{ Componentes } & $m g 100 g^{-1}$ & Componentes & $p p m$ \\
\hline $\mathrm{P}$ & $43-605$ & $\mathrm{Br}$ & $4,8-8,5$ \\
$\mathrm{Ca}$ & $10-120$ & $\mathrm{~B}$ & $4,5-8,6$ \\
$\mathrm{Mg}$ & $46-216$ & $\mathrm{I}$ & $0,5-3,87$ \\
$\mathrm{Na}$ & $0-332$ & $\mathrm{Li}$ & traços \\
$\mathrm{K}$ & $1394-2825$ & $\mathrm{As}$ & 0,35 \\
$\mathrm{Fe}$ & $3-18,5$ & $\mathrm{Co}$ & 0,07 \\
$\mathrm{~S}$ & $43-423$ & $\mathrm{Ni}$ & 0,26 \\
$\mathrm{Cl}$ & $45-805$ & $\mathrm{Mo}$ & 0,26 \\
$\mathrm{Zn}$ & $1,7-2,2$ & & \\
$\mathrm{Cu}$ & $0,6-2,8$ & & \\
$\mathrm{Si}$ & $5,1-17,3$ & & \\
$\mathrm{Mn}$ & $0,18-8,5$ & & \\
$\mathrm{Al}$ & $0,2-3,54$ & & \\
\hline
\end{tabular}

O 'Atlantic' é um dos poucos cultivares que possui baixos teores de açúcares redutores mesmo quando imaturo. Esta é a principal razão de seu uso para a produção de "chips", sendo um dos cultivares mais plantados para este fim nos Estados Unidos. Destaca-se, também, por possui alto teor de sólidos, mesmo sendo de ciclo precoce (Elma Chips, 2000).

A batata é uma das culturas que apresenta maior produção de energia e proteína por hectare por dia. Apresenta em média 2,1\% de proteína total, que significa cerca de $10,4 \%$ do peso seco do tubérculo. Isto pode ser considerado excelente se levarmos em conta que o trigo e o arroz apresentam valores na ordem de 13 e 7,5\%, respectivamente. Considerando-se as produções e teores de proteínas de cada cultura, as batatas podem render cerca de $300 \mathrm{~kg} \mathrm{ha}^{-1}$ de proteínas, enquanto que, o trigo 200 $\mathrm{kg} \mathrm{ha}^{-1}$ e o arroz $168 \mathrm{~kg} \mathrm{ha}^{-1}$ (Pereira, 1987).

A industrialização da batata vem crescendo em todo mundo, inclusive no Brasil, principalmente para produtos que podem ser consumidos diretamente ("ready to eat"), como chips e batata palha, ou, prontos para serem preparados ("ready to use"), como batatas descascadas ou cortadas em palitos resfriados e pré-fritas congeladas. Nos Estados Unidos e Holanda, $60 \%$ da produção de batatas são destinados ao processamento industrial, enquanto que, no Brasil, apenas 1,5 a 2,0\% são destinados a essa finalidade (Zorzella et al., 2003). 
O desenvolvimento da agroindústria de batata 'chips' e 'palha', no Brasil, tem sido limitada pela falta de matéria-prima adequada ao processamento. Todos os cultivares disponíveis para esse fim, até o momento, são originários de países de clima temperado, não sendo completamente adaptados às condições edafoclimáticas brasileiras e à pressão de inóculo de diversas doenças. Por outro lado, os cultivares nacionais, embora adaptados, não apresentam as qualidades necessárias para a industrialização (Popp, 1994).

O volume de batatas processadas pelas indústrias, no Brasil, está longe dos padrões de países como os Estados Unidos, por exemplo. Apenas 3 a $5 \%$ dos produtores brasileiros de batata entregam seu produto à indústria. Nos EUA, o total de batata processada representa $2 / 3$ da produção, estimada em 23 milhões de toneladas, o que corresponde a aproximadamente dez vezes a produção brasileira (Berbari \& Aguirre, 2002).

O rendimento das batatas utilizadas nas indústrias para serem convertidas em fécula, purê em pó, "chips" ou batata frita é tanto mais elevado quanto maior for a percentagem de matéria seca. O teor de MS depende de vários fatores, que são influenciados pela maturação dos tubérculos, pelo tipo de crescimento e pelo consumo de água e sais minerais (Zaag, 1993).

Com o aumento do consumo de batata na forma processada, as indústrias têm demandado novos cultivares, que proporcionem um produto final de boa qualidade. No Brasil, o tipo industrializado predominante é o 'chips ' (Silva, 1991).

Segundo Melo (1999), para obter tubérculos com alto teor de MS, a primeira medida a ser tomada é plantar cultivares que tenham esta característica genética, e que apenas esta medida pode não ser suficiente, já que o acúmulo de matéria seca nos tubérculos pode ser alterado por diversas condições ambientais. Batatas com teores de MS mais altos produzem produtos processados de maior rendimento e melhor qualidade (Capézio et al., 1993).

\subsection{Batata-semente}

Em muitos países a batata ocupa um lugar de destaque, com suas múltiplas possibilidades de utilização, tanto do ponto de vista do produtor como do consumidor. 
Trata-se de uma cultura muito suscetível às doenças e às pragas, independente do local onde é cultivada. Algumas dessas doenças são intrinsecamente relacionadas com o solo, no entanto, muitas são transmitidas através do material de propagação. Por esse motivo, é importante limitar o maior número possível de fontes de contágio, o que se consegue através do uso de material de propagação de boa procedência e qualidade sanitária (Liefrink, s.d.).

No Brasil, bem como na maioria dos países produtores, a batata tem sido propagada por via vegetativa, utilizando-se batata-semente previamente brotada. Tal particularidade, constituí um sério fator limitante à expansão da cultura, já que o material de propagação é de aquisição difícil e onerosa, em muitas localidades produtoras ou com potencial para tal (Filgueira, 1987).

A batata-semente é um fator fundamental para garantir a boa qualidade e a produtividade em uma cultura de batata. O plantio da batata-semente de má-qualidade pode comprometer uma safra, mesmo que todas as outras condições sejam altamente favoráveis ao cultivo. Portanto, a utilização de uma batata-semente com boa sanidade, estado fisiológico e brotação adequada, são fundamentais para o sucesso da cultura (Furomoto \& Lopes, 1997).

O processo de produção de batata-semente visa à multiplicação de uma quantidade de sementes livres de vírus e doenças transmissíveis pelos tubérculos, até atingir um volume compatível com o custo e a demanda do mercado, observando-se que cada geração de multiplicação em campo, a qualidade do lote vai diminuindo devido à degenerescência fisiológica e fitopatológica. Em cada região ou país, o número de gerações permitido é diferente, assim como as nomenclaturas utilizadas para cada geração, dependendo das particularidades climáticas e tecnológicas (Hirano, 1987).

A aquisição de batata-semente de boa qualidade, muitas vezes, é inviável economicamente, devido a grande quantidade de insumos para a implantação da lavoura, cerca de $2 \mathrm{t} \mathrm{ha}^{1-}$, e o alto custo, em média, o valor unitário de batata-semente é superior a duas vezes o da batata-consumo (Daniels, 2001). Para minimizar este problema, é recomendada a produção de semente própria, por meio da multiplicação, em condições adequadas, durante duas ou mais gerações, de batata-semente de 
qualidade adquirida de produtores idôneos, ou de preferência, de batata-semente básica ou certificada (Costa, 1969; Daniels, 1983).

O plantio de batata no Brasil, começou no início do século XX, porém, somente na década de 1950 houve duas ações separadas com relação à produção e à certificação de batata-semente. A produção foi iniciada na Cooperativa de Cotia, no final da década de 1950, com a multiplicação de batata-semente importada da Europa, por seus cooperados. Na década de 1970, houve maior expansão da produção de batata-semente no país, inicialmente na região norte de Santa Catarina e, depois, no sul do Paraná, liderada pela mesma cooperativa e, em seguida, com o surgimento de grandes produtores autônomos (Hirano, 1987).

Na década de 1970 o Brasil importava mais de 500.000 caixas de batatasemente certificada da Europa. O governo lançou o Plano Nacional de Batata para reduzir as importações e criar tecnologia de produção de batata-semente nacional. A Embrapa começou o desenvolvimento da tecnologia de produção de batata-semente básica através da biotecnologia, pelo uso de cultura de meristema, multiplicação in vitro e produção de minitubérculos em telados, além do uso de teste Elisa para detecção de vírus. Nas décadas de 1980 e 1990, foram produzidos 25\% da necessidade nacional de batata-semente básica, servindo de modelo para novas empresas de produção de batata-semente, por meio de biotecnologia, contando atualmente com mais de 20 produtores nacionais (Hirano, 2002).

Cerca de $15 \%$ da produção mundial de batata destina-se às sementes, sendo menor este percentual, aproximadamente $10 \%$ nos países em que a produtividade é alta. A Holanda e o Chile chegam a destinar $25 \%$ e $15 \%$ da produção, respectivamente, para sementes, devido à exportação deste insumo. No Brasil, cerca de $13 \%$ da produção é destinada a sementes, mas apenas $20 \%$ a $30 \%$ desse total correspondem a sementes de qualidade, ou seja, certificada (Pereira \& Daniels , 2003).

A batata é normalmente propagada vegetativamente, através do plantio de tubérculos semente. Esses, ao contrário das sementes botânicas, nunca estão realmente em repouso absoluto, sofrendo uma constante série de modificações bioquímicas, desde o início da tuberização até o início da brotação. Um dos fatores mais importantes para a cultura é o estado fisiológico dos tubérculos e o 
correspondente desenvolvimento da sua brotação. Nas nossas condições onde o ciclo da cultura é bastante curto, estes fatores devem obrigatoriamente promover uma emergência rápida e uniforme das plantas, no sentido de ter um máximo desenvolvimento vegetativo, no menor período de tempo (Castro, 1976).

Apesar da batata ser propagada vegetativamente através do tubérculo, portanto, botanicamente classificada como "muda", universalmente é aceita como semente devido às suas características agronômicas serem mais estreitamente relacionadas com o material de propagação sexuada, na sua forma de manuseio plantio, armazenamento e comercialização, seguindo as normas internacionais de classificação, que subdivide as sementes em genética, básica, registrada e certificada (Hirano, 1987).

Nos países baixos, aplica-se desde 1948, o sistema de seleção clonal, para servir de fundamento à produção de batata-semente. Este sistema baseia-se numa planta, o clone original. Após serem selecionadas, as plantas são multiplicadas por um período de três a cinco anos, até pertencerem à categoria máxima, denominada " $\mathrm{S}$ ". Este material serve de base a uma nova multiplicação em determinadas categorias de elevada qualidade. Além da seleção clonal, também pode começar com material, fruto de uma multiplicação in vitro, plantas ou tubérculos. Podem ser multiplicados in vitro, minitubérculos ou microtubérculos, esse material produzido por produtores idôneos e devidamente supervisionados, é introduzido no sistema de seleção clonal (Liefrink, s.d.).

A boa sanidade é proporcionada pelas inspeções no campo, na colheita e no armazém, garantindo níveis toleráveis de doenças. Tubérculos com estas características são encontrados em batata-semente das classes básica, registrada ou certificada, produzidas por produtores especializados e cadastrados nas Secretarias de Agricultura dos Estados (Lopes \& Furumoto, 1997).

Em muitos países tropicais e sub-tropicais a demanda para a produção de batata ou batata-básica está crescendo rapidamente. Embora a batata possa ser propagada de várias maneiras, tubérculos-semente ainda são amplamente usados como material propagativo, que pode ser infectado por vários patógenos, causando a sua degeneração. Com isso, é necessário repor estoques de sementes velhas com 
sementes livres de doenças a cada safra. A multiplicação de míni-tubérculos, se aplicada em conjunto com técnicas tradicionais de produção de sementes, possibilita os agricultores a produzir suas próprias sementes de alta qualidade, reduzindo a dependência de fornecimento de sementes convencionais de fontes inseguras e de alto custo (Schulz et al., 1998).

A produção de batata-semente constitui uma das fases mais importantes da cadeia produtiva da batata, tendo evoluído muito ultimamente, tanto em quantidade, como em qualidade. Há 20 anos, o Estado de Santa Catarina era responsável por mais de $60 \%$ da batata-semente produzida no país, proporção que caiu para menos de $20 \%$, devido, principalmente, ao crescimento da produção em outros estados. Embora tenha perdido espaço para outras regiões, a produção de batata-semente da Região Sul ainda é a mais importante (Pereira \& Daniels, 2003).

O peso unitário ou tamanho da batata-semente deve ser considerado, pelas implicações de ordem agronômica e econômica que acarreta. Em ensaios conduzidos em Anápolis com o cultivar Spunta, variando-se o peso de 20 a 200g, a produtividade em toneladas por hectare não apresentou diferenças significativas, não havendo vantagem em se plantar batata-semente de maior tamanho. Tubérculos pesando entre 20 e $40 \mathrm{~g}$ mostrarem-se mais vantajosos para o produtor de batata-consumo, devido ao menor custo e ao bom desempenho agronômico. Como a batata-semente é comercializada em caixas contendo $30 \mathrm{~kg}$, uma embalagem com tubérculos menores possibilita maior rendimento e menor custo (Filgueira, 2003). Portanto, para o produtor de batata-consumo, que adquire o material de plantio, plantar batata-semente menor é mais vantajoso.

A propagação vegetativa ou assexuada é de grande importância para a fixação do conteúdo genético das plantas, pois possibilita a formação de clones. Os diferentes métodos de propagação vegetativa de plantas, além de permitirem a manutenção das características genéticas da planta matriz, via de regra reduzem o porte da planta e promovem a precocidade. Entretanto, a prática de clonagem em plantas de propagação vegetativa, apesar de permitir saltos significativos tanto em produtividade com o em qualidade do produto, com reflexos positivos no rendimento econômico do negócio agrícola, implica freqüentemente, em uma drástica redução na variabilidade genética 
presente em plantios comerciais, expondo os cultivos a maiores riscos frente a mudanças ambientais. Esses riscos são mais evidentes em ambientes sujeitos a estresses, a exemplo do que se verifica sob condições tropicais, nas quais a ocorrência de doenças e pragas é bastante acentuada (Valois et al., 2001).

A utilização de material propagativo de alta qualidade fitossanitária é indispensável para a obtenção de elevadas produtividades na cultura da batata. Doenças transmissíveis por semente, como viroses e murcha bacteriana, constituem-se em fatores limitantes, ocasionando em muitas regiões elevados prejuízos (Medeiros et al., 2002).

A primeira estratégia para o controle das doenças transmitidas via semente, tem sido o plantio de materiais sadios, oriundos de cultura de tecidos, onde a limpeza clonal e posterior indexação asseguram a qualidade fitossanitária do material produzido (Fortes et al., 1998), permitindo ganhos significativos de produtividade no cultivo da batata. Entretanto, há necessidade de métodos eficientes de produção de material propagativo e de técnicas que propiciem multiplicações rápidas com custos reduzidos.

A utilização de novas técnicas de propagação vegetativa através da cultura de meristema e posterior micropropagação de mudas, com alto padrão genético e fitossanitário disponibiliza materiais livres de viroses para a produção de batatasemente, denominados de minitubérculos e ou microtubérculos. Entretanto, é importante ressaltar que a aplicação da cultura de tecidos em diferentes áreas de interesse está condicionada a vários fatores que devem ser controlados de maneira adequada durante o processo, pois cada espécie ou cultivar difere geneticamente entre si e pode responder de forma diferente mesmo sob idênticas condições de cultivo, conforme relatam os autores Fortes \& Pereira (2003).

A primeira estratégia para o controle das doenças transmitidas via semente, tem sido o plantio de material propagativo de cultura de tecidos, onde a limpeza clonal e posterior indexação asseguram a qualidade fitossanitária do material produzido (Fortes et al., 1998). Essa técnica tem permitido, ganhos significativos de produtividade no cultivo da batata. Entretanto, há necessidade de métodos eficientes de produção de material propagativo e de técnicas que propiciem multiplicações rápidas com custos reduzidos. 
A utilização de material propagativo de alta qualidade fitossanitária, é requisito indispensável para a obtenção de elevadas produtividades na cultura da batata. Doenças transmissíveis por semente, como viroses e a murcha bacteriana, são fatores limitantes da produtividade, ocasionando, em algumas regiões, elevados prejuízos. Levantamento da incidência de viroses em áreas de produção de batata-semente a partir de material pré-básico, nas principais regiões produtoras dos Estados de Santa Catarina e do Rio Grande do Sul, revelou índices de infecção de até 35\% das plantas amostradas, atingindo níveis de $42 \%$ no caso específico de algumas cultivares (Daniels et al., 2000b).

Estudos realizados por Dias (1996) verificaram que os benefícios da produção de batata-semente pelo próprio produtor estão relacionados com a redução dos custos com a compra de batata-semente de alta sanidade, com a eliminação de gastos com frete e com a possibilidade de se evitarem os riscos de introdução de microorganismos como aqueles vindos de outras localidades, assim como a introdução e disseminação das viroses que passam pelo tubérculo.

Avaliações comparativas realizadas com plantas de uma mesma cultivar de moranguinho, infectadas com vírus, mostraram que aquelas livres destes patógenos, via cultura de ápices meristemáticos, eram duas vezes mais produtivas. Atualmente sabe-se que a produção de matrizes, a partir de meristemas isolados em conjunto com o uso de cultivares resistentes, é a forma mais efetiva de evitar os danos causados pelas viroses (Kerbauy,1997).

A transferência das plântulas das condições assépticas da cultura de tecidos para um ambiente externo, normalmente casa de vegetação, para seu crescimento e desenvolvimento compreende a etapa da aclimatação. Esse processo deve ser feito cuidadosamente, ou um número significativo de plantas não sobreviverá. Quando as plântulas sofrem o processo de aclimatação, ficam sujeitas ao forte estresse ambiental que pode matá-las. Associadas a pouca funcionalidade dos estômatos, essas plantas são sensíveis a grandes perdas de água por transpiração que as levam ao dessecamento e ao murchamento das folhas, que são causas da baixa sobrevivência no transplante (Huylenbroeck \& Debergh, 1996). 
Vieira e Glória (2001), destacam a aclimatação como uma das etapas mais importantes no processo de micropropagação. As plantas são retiradas do frasco, as raízes devem ficar livres dos resíduos de meio de cultura, por lavagem em água, e as plantas transferidas para a casa de vegetação em suportes contendo substrato autoclavado. Inicialmente, se mantém a umidade, colocando sacos plásticos sobre as mudas as quais sofrem pulverização diária com água. Gradualmente, as plantas passam a adquirir vigor tornando-se aptas para o plantio.

\subsection{Cultivo hidropônico}

A hidroponia tem despertado interesse crescente no mundo todo, devido contribuir para redução dos impactos ambientais. Trata-se de é uma técnica alternativa de cultivo de plantas em solução nutritiva na ausência ou na presença de substratos naturais ou artificiais. De modo geral, o aumento da produtividade com menor impacto ambiental, a maior eficiência na utilização de água de irrigação e fertilizantes, a redução da quantidade ou eliminação de alguns defensivos e maior probabilidade de obtenção de produtos de qualidade são as principais vantagens dessa tecnologia de cultivo (Rodrigues, 2002).

Cultivo hidropônico bem-sucedido exige um grande volume de solução nutritiva ou ajuste freqüente da solução nutritiva, para impedir que a absorção de nutrientes pelas raízes produza mudanças radicais nas concentrações de nutrientes e no pH do meio. Um suprimento satisfatório de oxigênio ao sistema radicular, também crítico, pode ser alcançado borbulhando-se vigorosamente ar pelo meio (Taiz \& Zeiger, 2004).

O sistema hidropônico de produção, já consagrado em diversas culturas, mostra-se vantajoso para a produção de sementes pré-básicas de batata, pois aumenta a produtividade, reduzindo os custos e eliminando qualquer risco de contaminação por patógenos de solo (Medeiros et al., 2000).

A produção de batata-semente de alta qualidade passa pela cultura de tecidos e uma ou mais gerações de multiplicação em condições controladas, para preservar a qualidade sanitária dos tubérculos-semente (Fiorezze, 1997). Para a multiplicação de tubérculos-semente visando à produção comercial para posterior distribuição aos 
produtores, o cultivo hidropônico empregando substratos é mais adequado, por razões de simplicidade operacional, custos mais baixos, menor risco e maior inércia térmica.

Para o aumento da produtividade, faz-se necessário empregar batata-semente de alta qualidade, produzida a partir da cultura de tecidos e uma ou mais gerações de multiplicação em condições controladas. Essa é uma das variáveis que deve ser levada em conta na determinação da freqüência das fertirrigações, a qual deve ser ajustada de acordo com a demanda hídrica da cultura (Andriolo, 1999). No caso da batata o emprego de sistemas hidropônicos na produção de tubérculos-semente é ainda recente, necessitando de uma gama maior de informação.

O cultivo hidropônico de plantas, na sua conceituação moderna, é bastante recente e faz parte de uma área maior do conhecimento denominada "cultivos sem solo". No Brasil, o cultivo hidropônico em escala comercial vem crescendo de forma rápida, destacando-se os estados de São Paulo, Minas Gerais e Rio Grande do Sul que vêm desenvolvendo pesquisas pioneiras para a implantação da hidroponia (Santos, 2000).

Até recentemente a única tecnologia disponível para a formação do estoque nuclear era a seleção clonal realizada em países ou locais com ambiente especialmente favorável à produção de técnicas de multiplicação rápida do material propagativo. Nas últimas décadas, intensificou-se a adoção do cultivo de meristemas para a formação de mudas in vitro livres de patógenos que, após micropropagação constitui o material de origem para o cultivo em ambiente protegido e posterior formação do estoque nuclear de batata-semente, comumente referido como material pré-básico (Granja et al., 2003).

Diferentes sistemas hidropônicos vêm sendo empregados em diversos países, como forma de substituir os métodos convencionais de produção de tubérculos semente (Chang et al.,2000; Romanenko, 1997), mas que nem sempre atingem os índices de multiplicação desejados (Le Hingrat et al., 1999). No Brasil, os resultados até então alcançados revelam importante avanço no processo produtivo de batatasemente, capaz de contribuir para a eliminação de um de seus pontos de estrangulamento: a baixa taxa de multiplicação de tubérculos pré-básicos (Medeiros et al., 2002). 
No solo são aplicadas quantidades maiores e desuniformes de fertilizantes e há perdas por lixiviação e percolação. Nos sistemas hidropônicos fechados, a quantidade de fertilizantes é menor do que nos cultivos convencionais (Rodrigues, 2002). O sistema exige o fornecimento regular de uma solução nutritiva completa, cujos volumes consumidos durante o ciclo de produção dependem principalmente da transpiração diária da cultura (Baille, 1994).

Nesse contexto, a utilização de sistemas hidropônicos para produção de sementes pré-básicas de batata afigura-se como uma técnica vantajosa. Os estudos iniciados em 1998, com a produção de sementes de batata em cultivo sem solo (Medeiros \& Silva, 1999) indicam ser essa uma alternativa válida para a substituição dos processos produtivos atualmente em utilização.

A solução nutritiva é o meio pelo qual os nutrientes previamente dissolvidos na água são colocados à disposição das plantas e, é tida como uma das partes mais importantes de todo o sistema hidropônico, sendo que o mau uso desta pode acarretar sérios prejuízos para as plantas (Martinez \& Silva Filho, 1997; Andriolo, 1999). Furlani et al. (1999), salientam que muitos cultivos hidropônicos não obtêm sucesso, principalmente devido ao conhecimento dos aspectos nutricionais desse sistema de produção o qual requer formulação e manejo adequados das soluções nutritivas.

A recente intensificação da horticultura e principalmente a sua concentração em determinadas regiões produtoras criaram problemas tanto de ordem nutricional, como salinização do solo e/ou antagonismo entre nutrientes, quanto de sanidade do sistema radicular, pois aumentou a incidência de doenças provocadas pelos patógenos que vivem no solo (Abak \& Celikel, 1994; Andriolo et al., 1997), citados por Fernandes et al., (2001). Esta situação é bastante preocupante, pois pode inviabilizar o cultivo de espécies hortícolas em áreas fortemente atacadas. Assim, na busca de novas alternativas de cultivo verificou-se a possibilidade de produção destas espécies em substratos.

O cultivo em substrato possibilitou grande número de produção de biomassa, regularização do hábito de crescimento e aumento de pegamento pós-transplante, além de maior facilidade de organizar e programar a produção (Lemaire, 1995). 
Atualmente, encontram-se no mercado substratos formulados pelos mais variados tipos de materiais e proporções de misturas sem quaisquer restrições quanto à origem desses componentes ou composição de misturas. Isso ocorre porque as normas para produção e fiscalização de substratos no Brasil, ainda não estão definidas (Fabri et al., 2004).

A escolha do substrato determinará o tipo de estrutura para produção das mudas. O substrato mais adequado deverá atender às seguintes características: ser inerte quanto ao fornecimento de nutrientes, ter $\mathrm{pH}$ neutro e apresentar retenção de água e porosidade adequadas para oxigenação das raízes, oferecer sustentação para a muda e proteger as raízes dos danos físicos (Furlani, et al., 1999).

É importante destacar, no que diz respeito aos substratos a importância das suas características físicas, segundo Verdonck (1983), as considera até mais importantes do que as propriedades químicas, visto que as propriedades físicas vão determinas características importantes, como aeração e capacidade de retenção de água, e não podem ser modificadas durante o cultivo. Enquanto que, as propriedades químicas, como concentrações de sais, teores de nutrientes, valores de $\mathrm{pH}$ e de $\mathrm{CE}$ podem ser modificadas através da irrigação e da fertirrigação (Milner, 2002).

$\mathrm{O} \mathrm{pH}$ influencia diretamente na solubilidade e disponibilidade dos nutrientes na solução presente no ambiente radicular, afetando ainda a capacidade de troca catiônica dos substratos, podendo também ter efeito direto sobre a planta. $O$ nível adequado de pH em água no ambiente radicular deve ficar entre 5,0 e 6,0 (Milner, 2001).

No caso de substratos organo-minerais, deve-se considerar a CE (condutividade elétrica) e a sua CTC. A CE está relacionada à concentração inicial de sais solúveis no presente substrato, indicando se há necessidade de se adicionar nutrientes ou não. $\mathrm{A}$ acumulação excessiva de sais no substrato é conhecida como salinidade, e pode ser causada por diversos fatores, como a presença excessiva de sais em alguns componentes do substrato, adição e nutrientes em excesso na solução nutritiva ou na fabricação de substratos, podendo influenciar na germinação das sementes (Miner, 1994).

Com relação a CTC, esta é definida como a quantidade de cátions presentes na superfície do substrato e que podem ser trocados com os cátions da solução nutritiva 
(Martinez, 2002). O mesmo autor observa que em substratos onde este parâmetro alcança valor elevado, os nutrientes podem ser retidos e liberados gradualmente para as plantas. Quanto maior a CTC do substrato, menor deve ser a freqüência de fertirrigação.

Entretanto, uma grande parte das soluções nutritivas não tem capacidade tampão, dessa forma o pH varia continuamente, não se mantendo dentro de uma faixa ideal. Variações na faixa de 4,5 a 7,5 são toleradas, sem problemas ao crescimento das plantas. No entanto, valores abaixo de 4,0 afetam a integridade das membranas celulares e valores superiores a 6,5 deve-se ter atenção redobrada com possíveis sintomas de deficiência de Fe, P, B e Mn (Furlani, et al., 1999).

A maior produtividade normalmente obtida nos sistemas hidropônicos, comparativamente ao cultivo tradicional, deve-se fundamentalmente à ausência de enfermidades radiculares, desde que utilizado material isento de patógenos, e ao melhor controle sobre a nutrição das plantas, através do uso de solução nutritiva adequada à espécie (Caldevilla \& Lozano, 1993). A solução permite manter junto às raízes a concentração desejada de nutrientes, procedendo-se os ajustes sempre necessários. Da mesma forma, pode-se manter os valores de pH da solução em faixas pré-estabelecidas, otimizando a absorção de nutrientes (Martinez \& Alvarez, 1993).

Segundo Furlani et al., (1999), quando se procede à análise das exigências nutricionais de plantas visando o cultivo sem solo, devem-se enfocar as relações entre os nutrientes, pois esta é uma indicação da relação de extração do meio de crescimento, diferentemente do cultivo em solo, onde se procura fornecer as quantidades de nutrientes exigidas pela cultura através do conhecimento prévio das quantidades disponíveis no solo.

Conforme Hoagland \& Arnon (1950), relatam que, um adequado fornecimento de nutrientes está diretamente relacionado com o volume de solução, estádio de desenvolvimento das plantas, taxa de absorção de nutrientes e freqüência da renovação e reposição de nutrientes na solução nutritiva.

A composição ideal de uma solução nutritiva depende não somente das concentrações dos nutrientes, mas também de outros fatores ligados ao cultivo, incluindo-se o tipo ou o sistema hidropônico, os fatores ambientais, a época do ano, 
duração do período da luz, estádio fenológico, a espécie vegetal e o cultivar em produção (Furlani et al., 1999).

Quanto maior for o volume de solução por planta, menores serão as alterações nas concentrações de nutrientes, além disso, um maior volume por planta, permite um maior contato dos elementos essenciais com o sistema radicular e uma maior diluição dos efeitos de substâncias tóxicas ou inibitórias, que por ventura possam estar inseridas nos sistemas (Jones Junior., 1983).

As espécies e as cultivares têm exigências diferentes em relação à quantidade e à forma química do mesmo de nutriente. $O$ tomateiro por exemplo é mais exigente em cálcio, fósforo e potássio do que a alface. O nitrogênio pode ser absorvido pelas plantas na forma de nitrato $\left(\mathrm{NO}^{3-}\right)$ ou amônio $\left(\mathrm{NH}^{4+}\right)$. A absorção de nitrato varia conforme a cultivar e intensidade luminosa como pode ser constatado em culturas de alface e em outras hortaliças (Rodrigues, 2002). O nitrogênio na forma amoniacal $\left(\mathrm{NH}^{4+}\right)$ não deve ultrapassar $20 \%$ da quantidade total de $\mathrm{N}$ na formulação (Furlani et al., 1999).

Não existe uma solução nutritiva considerada ideal. No entanto, é comum encontrar nos artigos a frase "solução nutritiva modificada de Hoagland", isto é, fórmulas derivadas da proposta em 1938, por Hoagland \& Arnon, conforme citação de Resh (1996), onde os valores expressos em (mg. $\left.{ }^{-1}\right)$ são : N-NO 3 (210), P(31), K (234), Ca (160), Mg (48), S (64), B (0,5), Cu $(0,02)$, Fe $(1,0)$, Mn $(0,5)$, Mo $(0,01)$ e Zn $(0,05)$. Também existe outra versão dessa solução com a adição de $\mathrm{N}-\mathrm{NH}_{4}$ (14), mantendo-se o $\mathrm{N}$ total constante, esses dois tipos de soluções têm sido as mais usadas em pesquisa com nutrição mineral de plantas e constituem a base para a formulação de inúmeras soluções nutritivas comerciais existentes em todo o mundo (Furlani, et al., 1999).

Em cultivos hidropônicos, a absorção é geralmente proporcional à concentração de nutrientes na solução próxima às raízes, sendo muito influenciada pelos fatores ambientes, tais como: salinidade, oxigenação, temperatura, pH da solução nutritiva, intensidade de luz, fotoperíodo, temperatura e umidade do ar (Adams, 1994).

Considerando o fato de absorção de nutrientes pelas plantas ser seletiva em função da espécie e cultivar, a reposição dos nutrientes durante o desenvolvimento das plantas sem afetar o balanço entre as suas concentrações na solução nutritiva passa a 
ser o maior desafio dos produtores que optaram pelo cultivo hidropônico (Furlani et al., 1999).

\subsection{Parâmetros de crescimento e absorção de nutrientes}

Um vegetal de interesse econômico, como uma planta de cultivo anual em crescimento, apresenta diferentes fases. No início, como depende de reservas contidas nas sementes, o crescimento é lento; posteriormente, após o desenvolvimento do sistema radicular e a emergência das folhas, a planta tem um rápido crescimento através da retirada de água e de nutrientes do substrato onde está e através da sua atividade fotossintética. Após atingir o tamanho definitivo, entra para a fase de senescência, que resulta em um decréscimo no acúmulo de matéria seca (Lucchesi, 1987).

De acordo com Gregory (1926), citado por Lucchesi (1987), um vegetal anual, em condições ecológicas adequadas, ocupa, no período total de crescimento, em termos de percentagem, 10 para germinar, 6 para emergir, 51 no grande período de crescimento, 15 para reprodução, 8 na maturação e 10 até a colheita. Portanto, durante o seu desenvolvimento, o vegetal ocupa, nas diferentes fases, diferentes períodos de crescimento e, conseqüentemente, seria de fundamental importância o conhecimento dos principais fatores externos, e os da própria planta, que poderiam afetar cada uma das fases até o final do ciclo da mesma.

A batata é uma planta de crescimento rápido, com grande exigência de nutrientes num curto período de ciclo vegetativo. Apesar da importância do seu cultivo, são raros os resultados de pesquisa sobre nutrição mineral e adubação para a região Sul de Minas, responsável por 90\% da produção do estado (Oliveira \& Miranda, 1981).

Diversos elementos químicos são indispensáveis à vida vegetal já que, sem eles, as plantas não conseguem completar o seu ciclo de vida. Esse é um dos critérios para caracterizar se um elemento é essencial ou não (Epstein, 1975). Um outro critério baseia-se no fato do elemento fazer parte de um componente ou metabólito essencial. Se as plantas recebem esses elementos, assim como energia da luz solar,elas podem sintetizar todos os compostos de que necessitam para um crescimento normal (Raij, 1991). 
O fator água também é um dos mais importantes para o vegetal, sendo considerado como essencial à vida, ao crescimento e ao desenvolvimento da planta. A água é o principal constituinte do vegetal, cerca de 80 a 95\% nas plantas herbáceas; atua no transporte deslocando solutos e gases, como reagente no metabolismo básico, na turgescência celular, responsável pela forma e estrutura dos órgãos, no mecanismo estomático, e é essencial também para o crescimento, através da expansão celular (Lucchesi, 1987). As culturas consomem durante o seu ciclo de desenvolvimento um volume enorme de água, sendo que cerca de $98 \%$ deste volume apenas passa pela planta, perdendo-se posteriormente na atmosfera pelo processo de transpiração (Reichard, 1978).

A absorção e translocação de sais são, provavelmente aumentadas por rápida transpiração, sendo que as plantas com grandes áreas foliares transpiram mais do que aquelas com áreas foliares menores. Entretanto, a maior perda de água pela transpiração ocorre através dos estômatos, com 80 a 90 \% da água escapando através deles, constituindo o principal sistema de controle da transpiração (Benincasa, 2002).

Ao contrário dos animais e microorganismos, os elementos químicos essenciais requeridos pelas plantas superiores são exclusivamente de natureza inorgânica. A identificação desses nutrientes atendeu aos critérios de essencialidade propostos por Amon \& Stout (1939), conforme citação de Resh (1996), ou seja: a) a deficiência ou a falta de um elemento impossibilita a planta completar o seu ciclo biológico; b) a deficiência é específica para o elemento em questão; c) o elemento deve estar envolvido diretamente na nutrição da planta quer seja constituindo um metabólito essencial, quer seja, requerido para a ação de um sistema enzimático.

Taiz \& Zeiger (1991), verificaram que com o desenvolvimento da planta, o crescimento dos diversos órgãos é intensificado até chegar ao máximo, em conseqüência do intenso acúmulo de biomassa e nutrientes. A estabilização do crescimento dos órgãos da planta, assim como a colheita dos frutos, diminui a força do dreno e conseqüente diminuição no incremento de biomassa e nutrientes alterando o padrão da taxa de absorção.

Nas regiões tropicais, sob altas temperaturas em pós-emergência inicial, as folhas são menores e mais numerosas, com formação de área foliar mais rápida do que 
em regiões mais frias. Entretanto, a longevidade das folhas é menor, as hastes são mais reduzidas e com formação de folhagem abaixo do suficiente para aproveitar a energia luminosa disponível para a produção de matéria seca. O crescimento das raízes é também mais reduzido, o que é uma desvantagem pela necessidade de absorção de água e de nutrientes. Altas temperaturas também causam atraso na formação dos tubérculos, redução da produção e problemas fisiológicos (Souza, 2003).

Em climas temperados, o número de tubérculos por planta, as taxas de crescimento dos tubérculos e o índice de colheita são maiores, devido aos efeitos sobre a fotossíntese e a respiração. Enquanto que, em regiões tropicais, os rendimentos totais são menores, bem como o conteúdo de matéria seca incorporada nos tubérculos. A redução em matéria seca corresponde, em média, a $1 \%$, para cada $1^{\circ} \mathrm{C}$ de aumento de temperatura média entre $15^{\circ} \mathrm{C}$ a $25^{\circ} \mathrm{C}$ (Midmore, 1987).

A absorção dos nutrientes é diferente de acordo com a fase de desenvolvimento da cultura, intensificando-se no florescimento, na formação e no crescimento dos frutos ou do órgão que será colhido, por isso, além da quantidade absorvida de nutrientes, deve ser considerada também, a sua concentração nos diferentes estádios de desenvolvimento (Haag et al., 1981; Vitti et al., 1994; Malavolta et al.,1997).

A cultura da batata é altamente responsiva às alterações ambientais, sobretudo aquelas de origem edáfica, especialmente relativo à fertilidade. Cultivares de batata para fins industriais, possuem respostas diferentes das demais cultivares, devido ao acúmulo de massa seca nos tubérculos, apresentando assim, comportamento diferenciado quando se refere à absorção de nutrientes, assumindo papel central para a obtenção de matéria-prima de qualidade e alto rendimento da produção (Bregagnoli, et al., 2004).

Atlantic é um dos poucos cultivares que possui baixos teores de açúcares redutores mesmo quando imatura. Esta é a principal razão de seu uso para produção de chips, sendo uma das variedades mais plantadas para este fim nos Estados Unidos. Apesar de possuir um excelente desempenho sob o aspecto industrial, possui um potencial de produção limitado, fornecendo bons resultados somente quando encontra uma conjunção de condições climáticas favoráveis, boas práticas de manejo da lavoura e batata-semente de alta sanidade (Elma Chips, 2000). 
Na ausência de uma curva de absorção de nutrientes, a produção de MS pode indicar uma boa aproximação do acúmulo de nutrientes. Em média, as plantas possuem cerca de $5 \%$ de nutrientes e minerais na MS, havendo diferenças entre as espécies e as quantidades totais exigidas dependem da produtividade (Souza \& Coelho, 2001).

A produção de MS dos tubérculos é influenciada pela disponibilidade do nitrogênio. Países de clima temperado têm demonstrado que o aumento da dose de nitrogênio ocasiona um aumento na produção de MS (Westerman \& Kleinkopf, 1985; Joern \& Vitosh, 1995; Meyer \& Marcum, 1998; Errebi et al., 1998). Entretanto, o potássio reduz a produção de MS e, sendo que o cloreto de potássio tem produzido mais efeitos negativos quando relacionado ao sulfato, porém a aplicação adequada de nitrogênio e potássio pode aumentar a produção de MS (Saffigna \& Keeney, 1977; Robert \& Dole, 1985).

A importância do conhecimento das necessidades nutricionais das plantas, desde a fase da muda é ressaltada pelo trabalho de Weston \& Zandstra (1986), que ao avaliarem o desempenho de mudas de tomate cultivadas sob diferentes condições, concluíram que as plantas originadas de mudas de forma adequada com $\mathrm{N}, \mathrm{P}$ e $\mathrm{K}$, apresentaram produtividades maiores e foram mais precoces do que aquelas originadas de mudas nutridas apenas com quantidades mínimas desses nutrientes.

Fayad et al. (1998), verificaram que as curvas de crescimento e de absorção de nutrientes pelo tomateiro, em função da sua idade, fornecem informações de grande importância para um plano de manejo e condução da planta, fertirrigação e adubação. Pelo exame dessas curvas são evidenciados os períodos em que as plantas absorvem em maior proporções os nutrientes, dando informações básicas sobre as épocas mais adequadas para aplicação dos fertilizantes.

Dependendo da espécie, estádio fenológico e do desenvolvimento do órgão da planta, o conteúdo de nitrogênio necessário para o crescimento pode variar de 2 a $5 \%$ do peso seco da planta. O estádio fenológico também pode influenciar na absorção das formas de nitrogênio. A forma de nitrogênio fornecida tem influência muito forte sobre a absorção de outros cátions e ânions (Marschner, 1995).

As atividades agronômicas correlacionadas a cultura da batata têm se desenvolvido por várias regiões do país. No tocante à nutrição mineral, pode-se dizer 
que se trata de uma cultura altamente exigente, sendo responsável por um elevado consumo de fertilizantes. Contudo, não se pode caracterizar a totalidade dos processos de adubação como adequados às características agronômicas da cultura. Em muitos casos, são verificadas aplicações excessivas de fertilizantes (Vale, 2003).

O conhecimento do processo da absorção de nutrientes de uma espécie ou cultivar oferece subsídios para um manejo adequado da solução nutritiva, pois mostra os picos de demanda por parte da planta, alterações nas taxas de absorção durante o ciclo da cultura e a proporção relativa entre os nutrientes no material seco (Martinez et al., 1997).

A exigência nutricional de uma cultura varia de acordo com as fases de seu ciclo de desenvolvimento. No caso da batata, o máximo de absorção para nitrogênio, potássio, magnésio e enxofre, ocorre entre 40 e 50 dias após a emergência da planta. Enquanto que, para o fósforo e o cálcio a absorção ocorre durante todo o ciclo vegetativo, até os 80 dias do plantio (Tavares et al., 2002). 


\section{MATERI AL E MÉTODOS}

\subsection{Localização e características gerais}

Este trabalho foi conduzido sob cultivo protegido na estufa pertencente ao produtor e Eng ${ }^{\circ}$ Agr ${ }^{\circ}$ Pedro Hayashi, no município de Vargem Grande do Sul, Estado de São Paulo, localizado na latitude 2147'28,2"S e na longitude 04653'04"W e 938 m de altitude. O experimento foi instalado no início de setembro de 2004, permanecendo até meados de novembro do mesmo ano, período que se realizou a colheita dos minitubérculos. Os dados climáticos da região durante o período do experimento encontram-se na Tabela 3.

Tabela 3. Valores médios das temperaturas (Interna e Externa) máxima e mínima mensal durante o período do experimento em Vargem Grande do Sul - SP

\begin{tabular}{llccc}
\hline $\begin{array}{c}\text { Período } \\
\text { (meses) }\end{array}$ & $\begin{array}{c}\text { Temperatura } \\
\text { Interna }\left({ }^{\circ} \mathrm{C}\right) \\
\text { Máxima }\end{array}$ & $\begin{array}{c}\text { Temperatura } \\
\text { Interna }\left({ }^{\circ} \mathrm{C}\right) \\
\text { Mínima }\end{array}$ & $\begin{array}{c}\text { Temperatura } \\
\text { Externa } *\left({ }^{\circ} \mathrm{C}\right) \\
\text { Máxima }\end{array}$ & $\begin{array}{c}\text { Temperatura } \\
\text { Externa } *\left({ }^{\circ} \mathrm{C}\right) \\
\text { Mínima }\end{array}$ \\
\hline Setembro/04 & 31,70 & 13,00 & 30,62 & 13,92 \\
Outubro/04 & 29,00 & 15,30 & 27,60 & 16,31 \\
Novembro/04 & 31,40 & 16,70 & 29,33 & 17,85 \\
\hline
\end{tabular}

*Fonte: Instituto Agronômico de Campinas - IAC

O experimento foi instalado em estufa tipo arco, com as seguintes medidas: pé direito de 4,0 m, vão central de 5,0 m e área total de 900,0 $\mathrm{m}^{2}$, com cobertura de polietileno transparente de espessura de $150 \mu \mathrm{m}$, e laterais cobertas com tela tipo antiafídeo. Internamente havia uma pequena área chamada de "berçário", coberta com tela tipo sombrite de malha $50 \%$ de abertura, onde foram mantidas as plântulas (mudas), denominadas de matrizes, transplantadas em bandejas próprias para produção de mudas. A área maior utilizada foi dividida em canteiros de alvenaria 
medindo nove metros quadrados cada um, os quais dispunham de um sistema de dutos individuais que permite tanto a entrada como a saída da água e/ou solução nutritiva por gravidade e, sobre estes dutos foi colocada uma camada espessa de brita fina, onde caixas plásticas, com capacidade de 13,0 L cada, foram dispostas lado a lado, resultando uma densidade populacional de 120 plantas $\mathrm{m}^{-2}$, referente à produção comercial de minitubérculos. As caixas foram preenchidas com substrato (Figura 1), onde as mudas foram cultivadas e suas raízes não ficaram restritas as caixas, se aprofundando pela brita, conforme o desenvolvimento da planta.

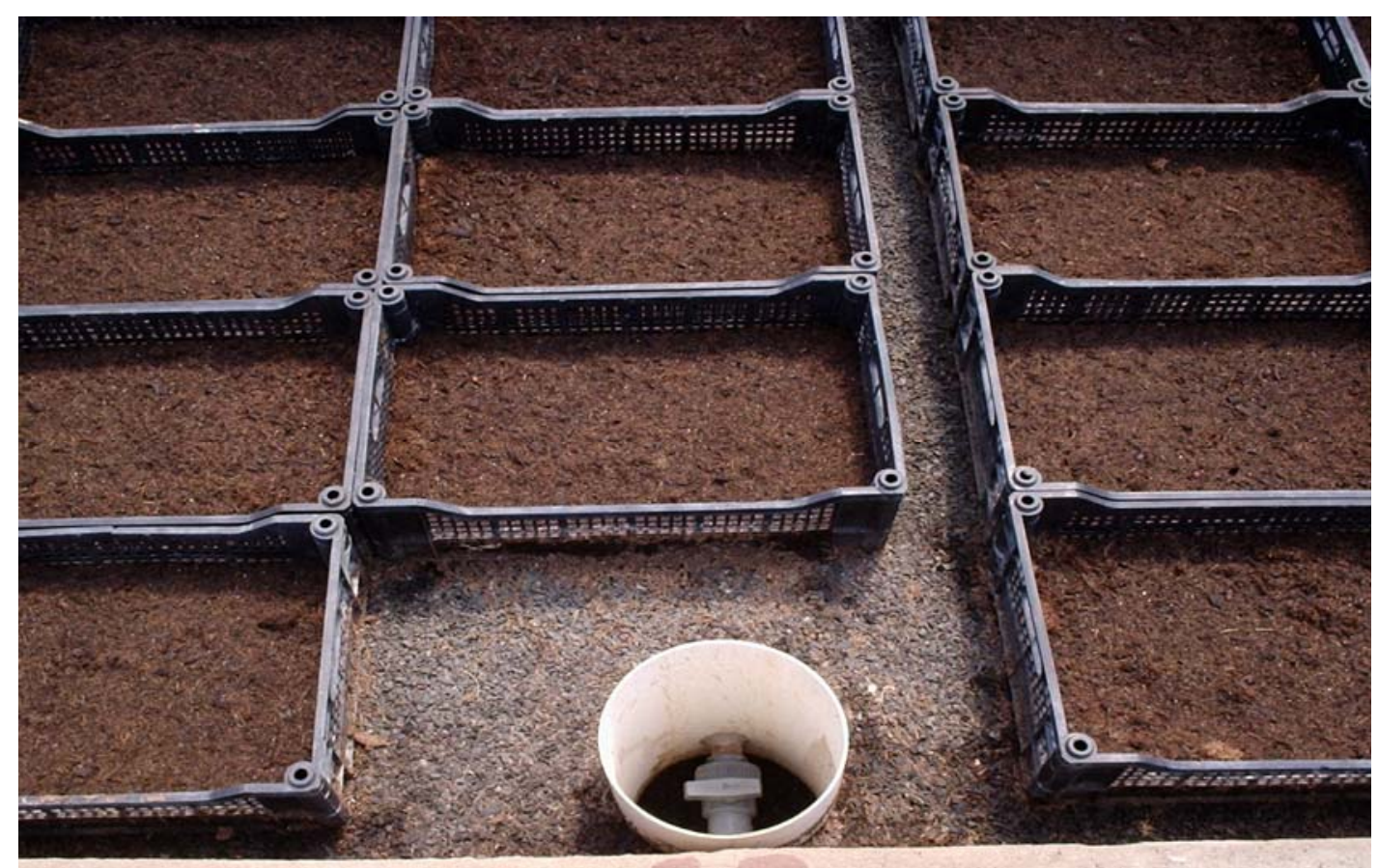

Figura 1 - Sistema de irrigação nos canteiros onde foram cultivados os mínitubérculos

Para isolar as mudas destinadas à avaliação, utilizou-se vasos plásticos, com capacidade de 1,0 L cada, contendo o mesmo tipo de substrato de fibra de coco, onde foi posta uma planta por vaso, conferindo uma densidade populacional de 70 plantas $\mathrm{m}^{-2}$ (Figura 2). 


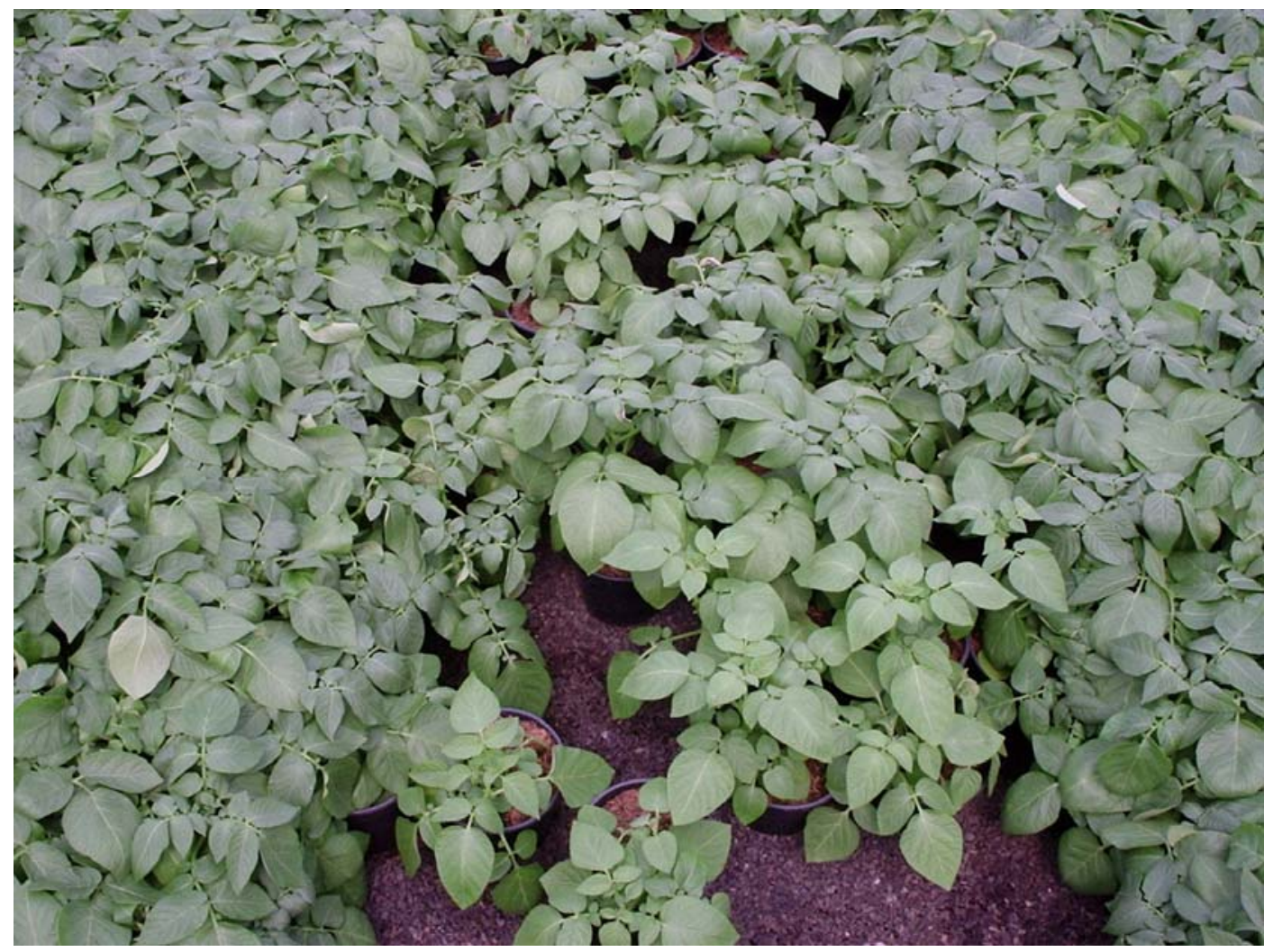

Figura 2 - Plantas em pleno estádio de desenvolvimento (32 DAT)

\subsection{Características dos substratos}

Os substratos utilizados foram: substrato para produção de mudas - Plantmax® ${ }^{\circledR}$ HA (composto por casca de pinus compostada, turfa, carvão vegetal e vermiculita) e fibra de coco - Golden Mix ${ }^{\circledR} 11$ (textura fibrosa). Para avaliação da qualidade dos substratos, as características químicas normalmente avaliadas são: $\mathrm{pH}, \mathrm{CE}$ (condutividade elétrica), macronutrientes e micronutrientes (Abreu et al., 2002). As análises químicas dos substratos foram realizadas no Laboratório de Análises Químicas de Substratos do Instituto Agronômico de Campinas - IAC, seguindo metodologia de Sonneveld et al. (1974) apresentaram as características químicas descritas na Tabela 4. 
Tabela 4. Características físicas e químicas dos substratos utilizados

\begin{tabular}{lcc}
\hline \multicolumn{1}{c}{ Componentes } & PLANTMAX® HA & GOLDEN MIX® \\
\hline $\mathrm{pH}$ & 6,0 & 5,0 \\
$\mathrm{CE}\left(\mathrm{dS} \cdot \mathrm{m}^{-1}\right)$ & 1,2 & 1,3 \\
$\mathrm{P}\left(\mathrm{mg} \cdot \mathrm{dm}^{-3}\right)$ & 82,9 & 21,2 \\
$\mathrm{~S}\left(\mathrm{mg} \cdot \mathrm{dm}^{-3}\right)$ & 300,0 & 91,8 \\
$\mathrm{~K}\left(\mathrm{mg} \cdot \mathrm{dm}^{-3}\right)$ & 24,3 & 230,4 \\
$\mathrm{Ca}\left(\mathrm{mg} \cdot \mathrm{dm}^{-3}\right)$ & 33,0 & 15,0 \\
$\mathrm{Mg}\left(\mathrm{mg}_{\mathrm{dm}}^{-3}\right)$ & 13,0 & 10,4 \\
$\mathrm{H}\left(\mathrm{mg} \cdot \mathrm{dm}^{-3}\right)$ & 28,0 & 37,0 \\
$\mathrm{Al}\left(\mathrm{mg} \cdot \mathrm{dm}^{-3}\right)$ & 0,0 & 1,0 \\
$\mathrm{MO}(\%)$ & 53,13 & 95,48 \\
$\mathrm{CTC}$ & 98,3 & 92,6 \\
$\mathrm{~V}(\%)$ & 71,5 & 60,5 \\
$\mathrm{C} / \mathrm{N}$ & 14,37 & 50,0 \\
$\mathrm{~N}(\%)$ & 2,15 & 1,10 \\
$\mathrm{Na}\left(\mathrm{mg} \cdot \mathrm{dm}^{-3}\right)$ & 144,0 & 9,6 \\
$\mathrm{Fe}\left(\mathrm{mg} \cdot \mathrm{dm}^{-3}\right)$ & 163,7 & 0,6 \\
$\mathrm{Mn}\left(\mathrm{mg}_{\mathrm{dm}}^{-3}\right)$ & 67,7 & 0,13 \\
$\mathrm{Cu}\left(\mathrm{mg} \cdot \mathrm{dm}^{-3}\right)$ & 5,8 & 0,1 \\
$\mathrm{Zn}\left(\mathrm{mg} \cdot \mathrm{dm}^{-3}\right)$ & 10,2 & 0,17 \\
$\mathrm{~B}\left(\mathrm{mg} \cdot \mathrm{dm}^{-3}\right)$ & 0,3 & 0,3 \\
\hline
\end{tabular}

\subsection{Solução Nutritiva}

Para a escolha da solução nutritiva, optou-se pela mesma utilizada pelo produtor a qual foi estabelecida de acordo com as necessidades nutricionais do cv. Atlantic, após sofrer vários ajustes, pelo próprio produtor. Os nutrientes utilizados, para 10.000 L de água, encontram-se na Tabela 3.

Tabela 5. Composição da solução nutritiva utilizada no experimento

\begin{tabular}{lc}
\hline \multicolumn{1}{c}{ Nutriente utilizado } & Solução Nutritiva $\left(\mathrm{kg} \cdot 10.000 \mathrm{~L}^{-1}\right)$ \\
\hline Nitrato de Cálcio & 11,000 \\
Nitrato de Potássio & 5,000 \\
Sulfato de Magnésio & 2,400 \\
Fosfato Monoamônio (MAP) & 2,200 \\
Hidro cocktail* & 0,150 \\
\hline
\end{tabular}

\section{Fonte dos nutrientes:}

Nitrato de Cálcio: Nitrogênio e Cálcio ( $12 \%$ de $\mathrm{N}-\mathrm{NO}_{3}$ e $17 \%$ de $\mathrm{Ca}$ )

Nitrato de Potássio: Nitrogênio e Potássio ( $13 \%$ de $\mathrm{N}-\mathrm{NO}_{3}$ e $36 \%$ de K) 
Sulfato de Magnésio: Magnésio e Enxofre ( $10 \%$ de Mg e 13\% de S) Fosfato Monoamônio (MAP): Nitrogênio e Fósforo (11\% de $\mathrm{N}-\mathrm{NH}_{4}$ e $21 \%$ de $\mathrm{P}$ )

* Hidro cocktail: Boro 2,0\%; Cobre EDTA 0,8\%; Ferro EDTA 5,6 \%; Molibdênio 0,32\%; Manganês EDTA 3,2 \%; Zn EDTA 2,0\%.

No período em que o experimento foi conduzido as fertirrigações foram feitas duas vezes por semana, por inundação e drenagem dos canteiros. A freqüência das fertirrigações depende da evapotranspiração da cultura (Etc), ou seja, a quantidade de água que a cultura consome por dia. Valores de ETc para as principais hortaliças variam conforme a temperatura, a umidade relativa do ar e a fase do desenvolvimento da cultura.

No sistema adotado, para o cultivo hidropônico de plantas em vasos plásticos com substrato de fibra de coco e inundação com solução nutritiva, o fluxo da solução nutritiva foi mantido de forma equilibrada, sendo esgotado e renovado constantemente, promovendo a drenagem, com o reaproveitamento da solução, de acordo com o desenvolvimento da cultura. Desta maneira o controle de CE e pH tornaram-se dispensáveis.

\subsection{Características do cultivar}

O cultivar utilizado foi Atlantic apto à industrialização, escolhido devido ao fato do produtor ter firmado contrato com uma indústria de batata tipo "chips" e este ser um dos poucos cultivares que possui baixos teores de açúcares redutores e teores altos de sólidos solúveis, características ideais para batata com finalidade industrial por proporcionar maiores rendimentos, além de possuir um ciclo precoce.

O cultivar Atlantic é originário dos Estados Unidos da América. Apresenta plantas de porte médio a alto, ereto e hastes grossas, de ciclo médio-precoce. Os tubérculos apresentam formato arredondado, polpa branca, película amarela ligeiramente reticulada, olhos semi-profundos e de brotação tardia. Possui baixa resistência a requeima (Phytophthora infestans B.), suscetibilidade a pinta preta (Alternaria solani S.), resistente ao vírus do mosaico leve viroses (PVX), suscetível ao vírus do enrolamento da folha (PLRV) e ao vírus do mosaico (PVY). Esse cultivar tem 
potencial de produção mediana, com percentagem alta de tubérculos graúdos, mesmo com doses médias de adubação. Apesar da grande adaptação às diversas regiões produtoras, é sensível à desordem fisiológica coração-oco. Exige tratamento cuidadoso para brotação da batata-semente para obtenção de bom estande. Apresenta alta percentagem de MS e é, especialmente indicada para o preparo de chips e batata-palha (Melo, 1999).

\subsection{Transplantio e condução das mudas}

As plântulas (mudas), provenientes do Laboratório de Biotecnologia Biovítrus, Campinas - SP são originadas a partir do meristema e indexadas através de testes para os vírus PLRV, PVX, PVS e MA, garantindo a sanidade do material a ser multiplicado.

No dia 03 de setembro de 2004, as mudas, contidas em potes fechados, próprios para cultura de tecidos, com solução nutritiva a base de Ágar, foram transplantadas em bandejas para produção de mudas, contendo substrato Plantmax ${ }^{\circledR}$ HA. Após o transplante e, periodicamente sempre que necessário, as mudas foram irrigadas até percolação. No dia 17 de setembro de 2004, as mudas foram novamente transplantadas para os vasos plásticos preenchidos com substrato de fibra de coco Golden Mix ${ }^{\circledR}$ 11, tipo fibroso, e levadas aos canteiros definitivos onde passaram a receber solução nutritiva freqüentemente até o período de colheita do material.

No interior da estufa, cada muda foi retirada cuidadosamente do pote para não afetar seu sistema radicular, fez-se a limpeza do material retirando o excesso da solução nutritiva de base e colocando-as nas bandejas. A operação foi realizada manualmente por pessoas treinadas para seguir o sistema adotado. O segundo transplantio foi realizado após o período de aclimatação e enraizamento que ocorre em torno de dez dias após o primeiro. Este período pode variar conforme o estado fisiológico da plântula vinda do laboratório, assim como as condições do ambiente.

As plantas matrizes transplantadas no início nas bandejas, não receberam fertirrigação, para preservarem seu estado fisiológico e, portanto obter maior aproveitamento no processo da taxa de multiplicação (Figura 3). Após o segundo transplantio, das bandejas para os vasos, as mesmas seguiram para os canteiros, onde foram fertirrigadas duas vezes por semana. 
O sistema de produção descrito é um pouco diferente dos demais adotados pelos produtores. O modelo inicial foi baseado no sistema utilizado pelo pesquisador científico Dr. Newton do Prado Granja do Instituto Agronômico de Campinas - IAC (Hayashi, 2004) e apresentou baixo custo, facilidade de manejo e confiabilidade para a produção de sementes com elevada sanidade (Granja et al., 2003).

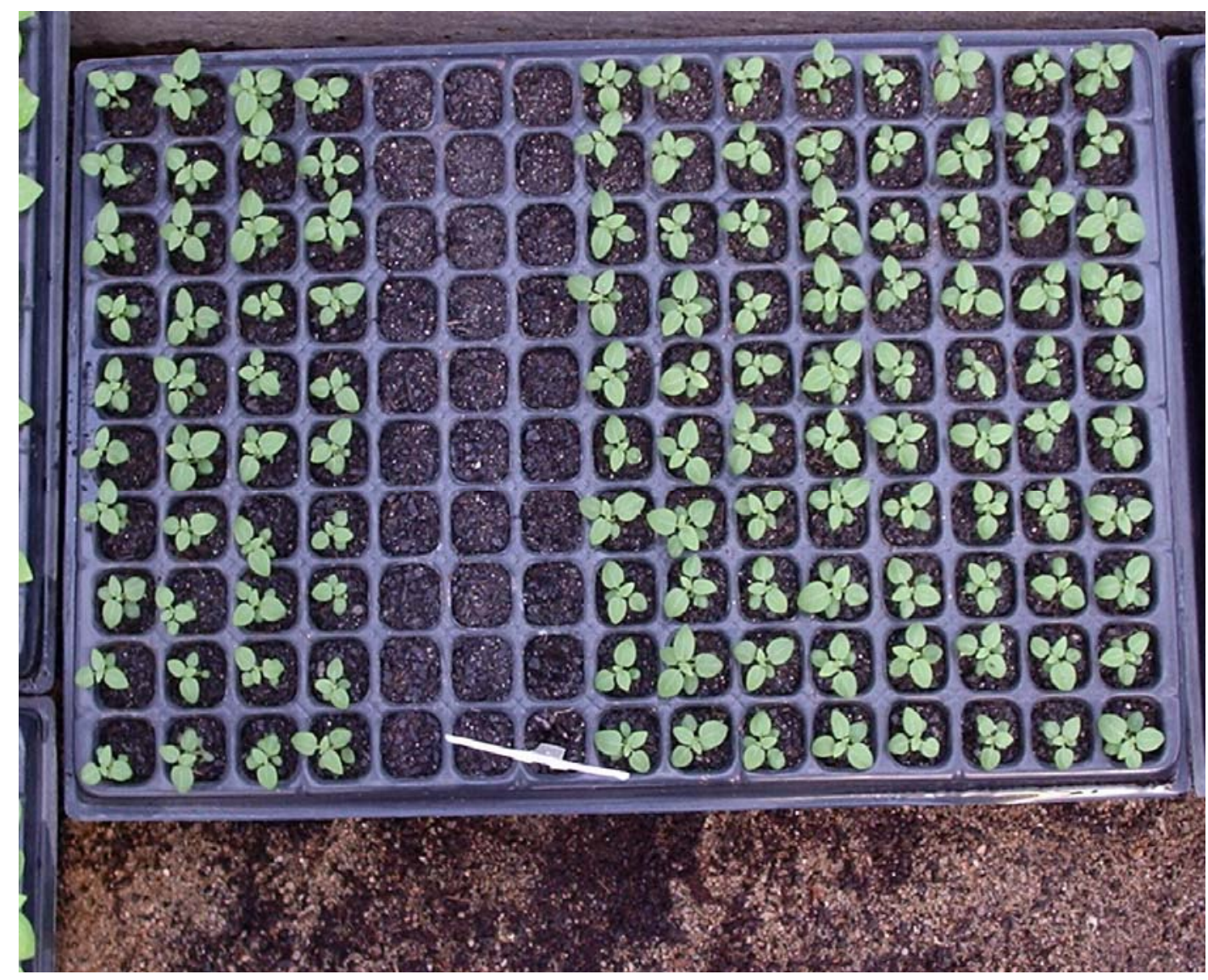

FIgura 3 - Plantas matrizes em bandejas de produção de mudas (7 DAT)

\subsection{Avaliação e coleta das plantas}

Semanalmente, até 70 dias após o plantio (DAP), foram realizadas avaliações quanto ao crescimento das plantas, através de um corte no nível do substrato separando a parte aérea do sistema radicular, medindo a altura da parte aérea, contando o número de folhas e o número de hastes de cada planta coletada. Foram 
também determinados o peso do material fresco e o peso do material seco de cada parte da planta (raiz, parte aérea e minitubérculos) em balança analítica.

Durante o período de condução do experimento, além das variáveis acima descritas, foram também avaliados o número de minitubérculos formados, o diâmetro de cada um, o peso do material fresco e o peso do material seco, verificando assim a produtividade e a qualidade dos minitubérculos produzidos por planta.

As coletas foram realizadas no período da manhã, para evitar que as plantas murchassem até chegarem ao laboratório, tendo início oito dias após o transplantio. 0 número de plantas coletadas, por parcela, foi sendo reduzido à medida que elas se desenvolviam. Na primeira amostragem (8 DAT) foram coletadas 20 plantas, sendo cinco plantas por repetição; na segunda (18 DAT) foram coletadas 12 plantas, três plantas por repetição; e a partir da terceira, até a última foram coletadas quatro plantas, sendo uma planta por repetição. As coletas foram realizadas seguindo sorteio pré-estabelecido. O desenvolvimento das plantas foi bastante rápido e vigoroso. Assim, do plantio no canteiro definitivo até a colheita final o período foi de 60 dias.

\subsection{Preparo das amostras}

Após remoção das plantas da estufa, elas foram mantidas inteiras nos respectivos vasos e imediatamente levadas ao Laboratório de Nutrição Mineral de Plantas da Escola Superior de Agricultura "Luiz de Queiroz". Posteriormente, as plantas foram cortadas no nível do substrato, separadas em parte aérea, subterrânea e minitubérculos formados. Foram, em seguida, devidamente separadas, sendo que cada parte da planta foi lavada, em duas etapas: água de torneira até remoção total das partículas dos substratos e em seguida foram mergulhadas, por alguns segundos, em bandejas plásticas contendo água desionizada. Após a lavagem, cada parte das plantas foi agitada por alguns segundos para remoção do excesso da água e logo depois determinou-se o peso fresco em balança analítica. Após a determinação do peso fresco, cada parte da planta foi colocada em saco de papel tipo Kraft, devidamente identificados e levadas para secagem em estufa sob ventilação forçada de ar a $65^{\circ}$ $70^{\circ} \mathrm{C}$, por um período de 48 horas, até atingirem peso constante, após este período, a massa das amostras foi determinada em balança analítica para obtenção de seus pesos 
secos. Em seguida, as amostras foram moídas em moinho tipo Wiley, com peneira de malha 20 mesh (1 mm) e armazenadas em saco plástico, devidamente identificados.

\subsection{Análise química das plantas}

Para a determinação dos teores de nutrientes presentes em cada parte das plantas, as análises químicas foram realizadas nos extratos obtidos pela digestãosulfúrica (nitrogênio), nítrico-perclórica (fósforo, potássio, cálcio, magnésio, enxofre, cobre, manganês e zinco) e por via seca (boro), metodologia estabelecida por (Sarruge \& Haag, 1974).

O nitrogênio foi quantificado pelo método semi-micro Kjeldahl; o fósforo por colorimetria do metavanadato e o boro por colorimetria do reagente azometina $\mathrm{H}$; potássio por fotometria de chama de emissão; cálcio, magnésio, cobre, ferro, manganês e zinco por espectofotometria de absorção atômica e o enxofre por turbidimetria do cloreto de bário (Sarruge \& Haag, 1974).

As análises forneceram os resultados das concentrações dos seguintes macronutrientes: nitrogênio, fósforo, potássio, cálcio, magnésio e enxofre em g kg-1 e dos seguintes micronutrientes: boro, cobre, ferro, manganês e zinco em g kg-1. Para determinação da quantidade total de nutrientes acumulados em cada parte da planta, foi multiplicada a concentração de cada nutriente pela biomassa seca da parte referida.

A primeira coleta de plantas, no início do desenvolvimento, após ser secada e moída, de acordo com a metodologia adotada, não forneceu material suficiente para as quatro repetições. Daí optou-se pelo agrupamento do material disponível e se formar uma amostra composta, resultando em apenas uma repetição para esse tratamento. Apesar de ter sido realizada a análise química das plantas, não foi incluída na análise estatística, portanto os resultados das análises foram apenas apresentados.

\subsection{Delineamento experimental}

O delineamento experimental empregado foi inteiramente casualizado com quatro repetições e seis tratamentos, referentes às épocas de coleta das plantas. Foram delimitadas 70 parcelas constituídas de uma planta por vaso, espaçados de 12 $\mathrm{cm}$ entre plantas. 
A análise de variância dos resultados do experimento foi realizada empregandose o programa estatístico SAS (1996), através de análise de variância e, quando esta foi significativa aplicou-se a análise de regressão.

\subsection{Controle fitossanitário}

Pulverizações semanais foram realizadas, de acordo com as necessidades de controle de doenças e pragas, seguindo recomendação de controle preventivo. A praga de maior ocorrência foi a mosca minadora (Liryomisa huidobresnis, B.), enquanto que as doenças mais freqüentes nas folhagens foram: pinta preta (Alternaria solani S.) e requeima (Phytophtora infestans B.), controladas com produtos específicos. Os produtos foram aplicados via bomba costal (20 litros), e foram usados em dosagens reduzidas, pois o ambiente da estufa pode propiciar a ocorrência de fitotoxicidade nas plantas de maneira mais expressiva.

A limpeza e desinfecção são extremamente importantes e fundamentais nos materiais utilizados, como: tesouras, bandejas, caixas plásticas, assim como no interior da estufa como um todo, para evitar disseminação de doenças, como por exemplo, viroses. 


\section{RESULTADOS E DI SCUSSÃO}

\subsection{Parâmetros de crescimento}

Os parâmetros de crescimento da produção de minitubérculos foram determinados em datas consecutivas de coletas, aos 18, 25, 32, 39, 46 e 53 dias após o transplantio (DAT) considerando as seguintes variáveis: altura das plantas, número de hastes planta ${ }^{-1}$, número de folhas planta ${ }^{-1}$, número de tubérculos planta ${ }^{-1}$, diâmetro nos minitubérculos, o peso do material fresco nos minitubérculos, o peso do material seco nos minitubérculos e assim como o peso do material seco total nas plantas determinado para os tratamentos. Os resultados obtidos referentes aos parâmetros de crescimento são apresentados nas Figuras (4 a 33). Adotou-se o modelo de regressão linear, devido ao sistema de produção de minitubérculos e, quando necessário aplicouse o modelo de regressão quadrático.

\subsubsection{Altura das plantas}

Com relação à altura das plantas, apresentou significância $(P<0,01)$ e 0 modelo de regressão linear ajustou-se melhor (Figura 4). Observou-se que a altura das plantas apresentou um crescimento constante, para $X \in[2 ; 7]$. A altura das plantas cresceu a cada semana $(X) 2,80 \mathrm{~cm}(Y)$. 


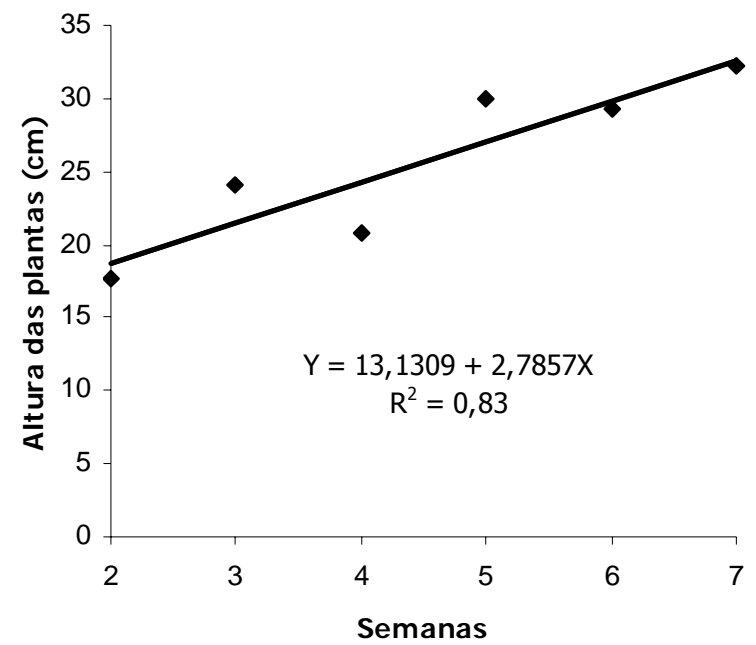

Figura 4 - Altura das plantas obtida para os tratamentos (cm)

Na semana 7, aos 53 DAT a altura atingida nas plantas foi $32,63 \mathrm{~cm}$. Entretanto, como o comportamento de crescimento apresentou-se contínuo e crescente para os tratamentos, o ponto máximo da altura não foi atingido no período de colheita.

Resultados obtidos por Melo et al. (2003), em condições de campo, confirmam a caracterização do cv. Ágata como cultivar de porte baixo mostrando comprimento inferior a $60 \mathrm{~cm}$, valor este estabelecido já aos 60 DAP, o que demonstrou a velocidade de desenvolvimento da variedade.

\subsubsection{Número de hastes}

O número de hastes por planta, foi significativo $(P<0,01)$ e ajustou-se ao modelo quadrático de regressão (Figura 5). No entanto, o maior valor obtido foi 4 hastes planta ${ }^{-1}$ entre a semana 5 e a semana 6 , aos 40 DAT. 


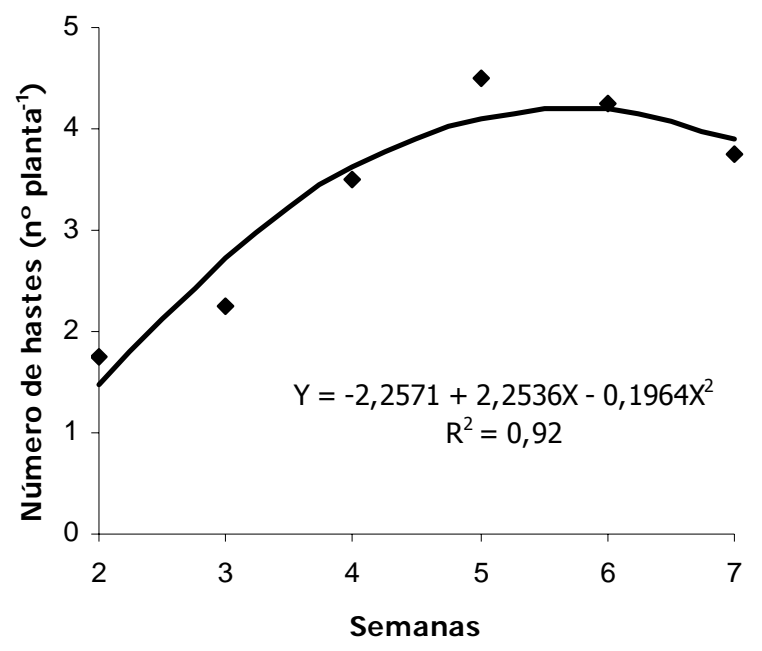

Figura 5 - Número de hastes por planta para os tratamentos ( $n^{\circ}$ planta $\left.^{-1}\right)$

Foi observado que o número de hastes nas plantas para os tratamentos apresentou uma relação positiva com o número de folhas emitidas nas mesmas.

O número de caules principais é determinado por fatores tais como tamanho do tubérculo da semente, o número de brotos por tubérculo, a densidade de plantação e a preparação do terreno. De um modo geral, pode-se dizer que existe uma relação positiva entre o número de caules e o desenvolvimento da folhagem (Zaag, 1993).

Resultados diferentes foram obtidos por Melo et al. (2003), em condições de campo, mostraram a formação de 10,1 hastes planta $^{-1}$ e 2,2 tubérculos haste $^{-1}$, no cultivar Ágata, porém estes valores devem ser considerados como aproximados, uma vez que foi considerada o total de hastes formadas e não apenas as principais.

\subsubsection{Número de folhas}

O número de folhas por planta atingiu um ponto máximo de 59 folhas por planta entre a semana 6 e a semana 7 aos 48 DAT, próximo ao período em que a planta atingiu o maior valor médio com relação à altura. Neste período as folhas estavam vigorosas, mesmo as baixeiras. Observou-se um ponto de estabilização, comportamento característico de planta em estágio de senescência, e a partir deste 
período inicia-se a perda de folhas. $O$ modelo de regressão quadrática $(P<0,01)$, ajustou-se melhor (Figura 6).

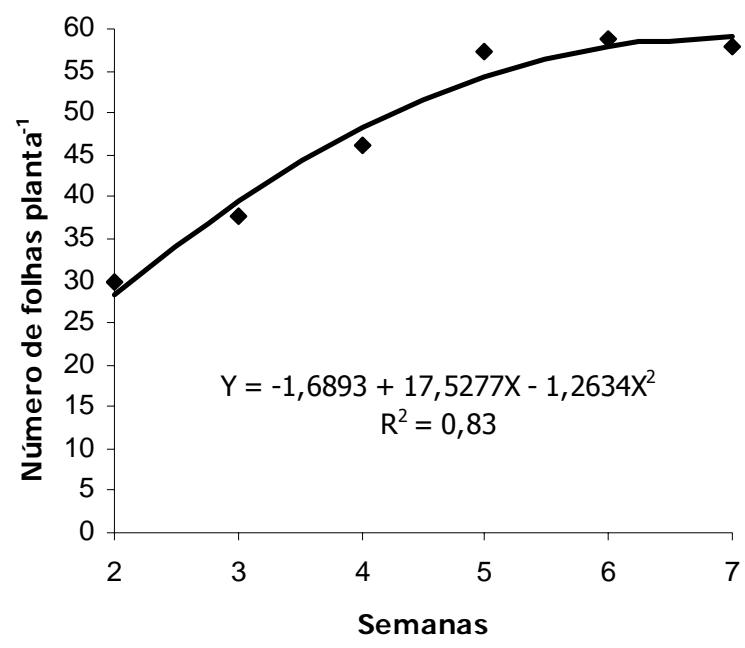

Figura 6 - Número de folhas por planta obtido nos tratamentos

Hang \& Miler (1986), investigando as respostas fisiológicas da cultura da batata ao estresse hídrico, observaram redução no tamanho das plantas, no número de folhas, na taxa de crescimento do tubérculo e acréscimo na partição de assimilados, em condições de campo.

Com relação ao número total de folhas não há grandes diferenças entre cultivares. Resultados semelhantes foram encontrados por Melo et al. (2003), no mesmo período, porém apresentando um número maior de folhas planta ${ }^{-1}$. Esses autores verificaram que o cv. Ágata atingiu um ponto máximo de 100 folhas planta ${ }^{-1}$, ao mesmo tempo em que as hastes atingiram a sua maior altura, pouco antes dos 50 DAP. Entretanto, a partir dos 70 DAP o número de folhas decresceu rapidamente, dado o envelhecimento das folhas que se deu aos 95 DAP.

O número de folhas é um fator extremamente importante. A maioria das pesquisas realizadas indica que a taxa de fotossíntese diminui consideravelmente à medida que a folhagem envelhece, ou seja, quando tiverem mais de 50 dias. Quanto mais alta a temperatura, tanto mais rápido o envelhecimento das folhas. Como as 
folhas jovens respiram mais rapidamente do que as mais velhas, as folhas mais eficazes são as que acabam expandindo-se completamente (Zaag, 1993).

\subsubsection{Número de minitubérculos}

Houve efeito significativo $(P<0,01)$ no número de minitubérculos planta ${ }^{-1}$ para os tratamentos. O modelo quadrático de regressão apresentou melhor ajuste para esta variável (Figura 7).

O número de minitubérculos produzidos foi de 6,7 minitubérculos planta-1 que corresponde aos 46 DAT. A taxa de multiplicação foi obtida pelo modelo quadrático de regressão. Observou-se que o melhor resultado obtido com relação à taxa de multiplicação encontra-se entre a semana 6 e a semana 7 aos 46 DAT.

A taxa de multiplicação obtida no presente trabalho, referente aos tratamentos, foi equivalente a 6,5 minitubérculos planta $^{-1}$, porém devem ser consideradas as condições de plantio utilizadas.

O número de tubérculos na primeira colheita, que ocorreu aos 32 DAT, foi relativamente pequeno. Apresentando valores médios de 3,5 minitubérculos planta ${ }^{-1} \mathrm{e}$ atingiu o pico $\left(6,7\right.$ minitubérculos planta $\left.{ }^{-1}\right)$ próximo à última colheita aos 53 DAT.

Entretanto, resultados reportados por Medeiros (2003), em sistema de calhas de PVC sobrepostas, mostraram que a maior produtividade é determinada pela colheita escalonada dos tubérculos quando ainda pequenos, o que estimula a diferenciação e a formação de outros. A energia que seria normalmente utilizada para o aumento do tamanho dos tubérculos, com eliminação dessa demanda, é carreada para a formação de novo material, propiciando altas taxas de multiplicação. 


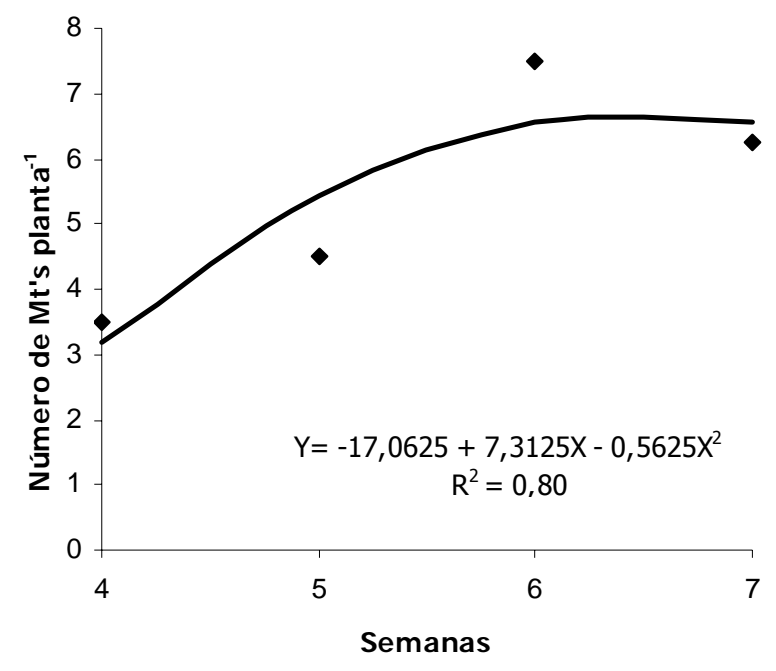

Figura 7 - Número de minitubérculos produzidos por planta para os tratamentos

O sistema hidropônico mostrou maior eficiência em relação aos métodos tradicionais, de produção de minitubérculos. A produtividade média obtida no sistema hidropônico situa-se na faixa de 15 a 20 tubérculos por planta, considerando-se o espaçamento de $20 \mathrm{~cm}$, o qual propicia a formação de elevada percentagem de tubérculos grandes. No entanto, a produtividade por área, conforme já referido, poderá ser aumentada pela diminuição do espaçamento entre plantas, obtendo-se tubérculos de tamanho menor (Medeiros, 2003). Já pelos sistemas tradicionais os valores máximos obtidos não ultrapassam 5 tubérculos por planta.

Resultados de pesquisa mostram que a taxa de multiplicação de batata-semente ainda é baixa, não alcançando valores superiores a 5 tubérculos planta ${ }^{-1}$. Correa et al. (2004), em casa de vegetação, observaram que em relação ao número total médio de tubérculos por vaso, houve efeito linear do número de plantas por vaso. Com uma planta, cada vaso produziu em média 16 minitubérculos. 0 número de minitubérculos aumentou linearmente até 5 plantas por vaso, onde se obteve cerca de 34 tubérculos por vaso em média.

\subsubsection{Diâmetro e peso do material fresco dos minitubérculos}

O diâmetro nos minitubérculos foi significativo $(P<0,01)$ e ajustou-se melhor ao 
modelo de regressão linear (Figura 8). Observou-se que o diâmetro nos minitubérculos apresentou um crescimento constante, para $X \in[2 ; 7]$. Os minitubérculos cresceram a cada semana $(X)$ aproximadamente $2,80 \mathrm{~cm}(Y)$.

Considerando os valores obtidos para os tratamentos, o maior diâmetro atingiu 23,0 mm na última coleta aos 53 DAT. De acordo com as normas de classificação este tamanho pertence ao tipo $\mathrm{V}(15$ a $23 \mathrm{~mm})$.

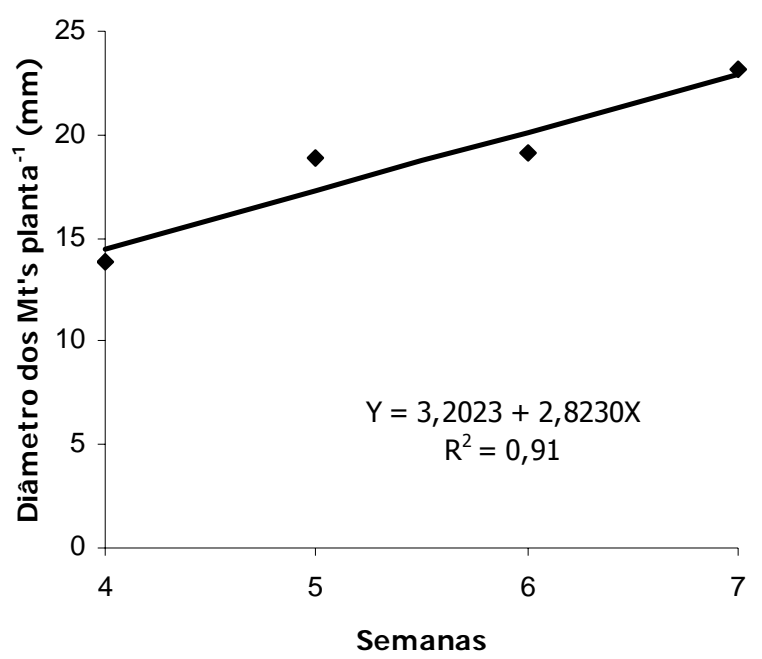

Figura 8 - Diâmetro dos minitubérculos por planta nos tratamentos

O cv. Ágata apresenta tuberização precoce e manifestou-se aos 35 DAP, ocorrendo a diferenciação dos estolhos em tubérculos até os $55 \mathrm{DAP}$, quando se estabilizou o número de tubérculos por planta. Esse pequeno período de definição do número de tubérculos, em torno de 15 dias, é característica marcante de 'Ágata', com uma produção de tubérculos normalmente uniformes de tamanho (Melo et al., 2003).

A colheita realizada em intervalos semanais, em sistema hidropônico, permite a obtenção de tubérculos com boa uniformidade, classificados como tipo $V$ e VI (Embrapa, 2000), com tamanho entre 13 e 23 mm, ou peso entre 3,0 e 6,5 g. 0 número de tubérculos na primeira colheita é relativamente pequeno, atingindo o pico, em geral, próximo à quarta colheita e declinando a partir daí. $\mathrm{O}$ fato de que os 
tubérculos são colhidos antes de a planta completar o ciclo não altera o potencial de brotação e o vigor da semente produzida (Daniels, 2003).

$O$ peso do material fresco total nos minitubérculos foi significativo $(P<0,01)$ para os tratamentos e ajustou-se ao modelo de regressão linear (Figura 9). O aumento no peso do material fresco dos minitubérculos apresentou-se de forma continua, no entanto, a partir de 40 dias o aumento do peso do material fresco foi bastante expressivo atingindo um valor de $16,10 \mathrm{~g} \mathrm{planta}^{-1}$ na semana 7 aos 53 DAT.

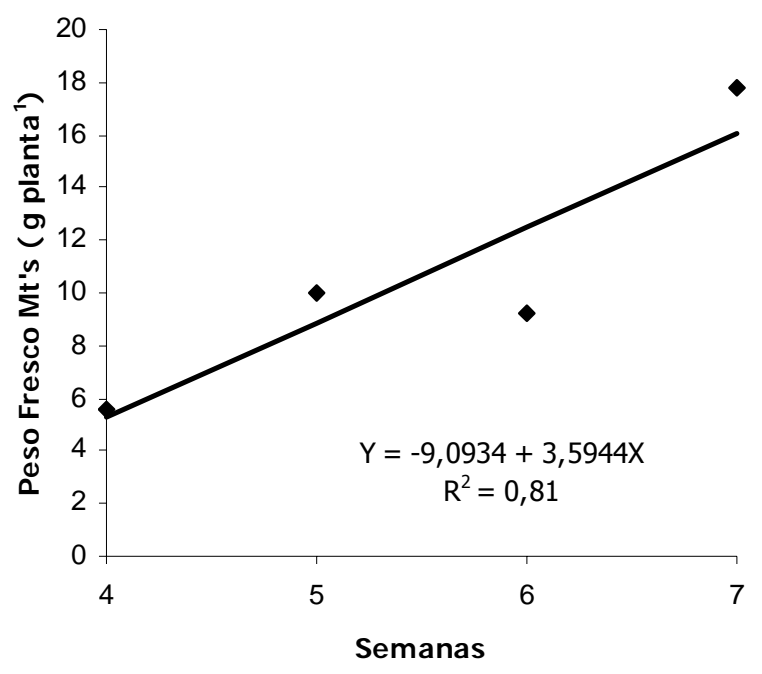

Figura 9 - Peso do material fresco nos minitubérculos por planta para os tratamentos

O diâmetro dos minitubérculos e o peso do material fresco dos mesmos apresentaram uma relação positiva. Na colheita os valores atingidos foram de $23 \mathrm{~mm}$ e $16,10 \mathrm{~g}$ planta ${ }^{-1}$, respectivamente.

Em condições de campo, o início do aumento linear do peso dos tubérculos ocorreu aproximadamente 27 DAE em plantas de tubérculos de tamanho comercial, enquanto que, em plantas de microtubérculos este processo iniciou $38 \mathrm{DAE}$. Porém, a taxa de aumento do peso dos tubérculos foi semelhante entre plantas originadas de tubérculos comerciais e microtubérculos, resultando em maior peso de tubérculos na época de máximo desenvolvimento foliar, em plantas originadas de tubérculos comerciais (Kawakami, 2004). 
Quanto maior o peso do tubérculo, maior a quantidade de reserva que o mesmo terá para emitir brotação. Porém, um tubérculo menor terá menos reserva, mas emitirá brotos da mesma forma, em igualdades de condições (Corrêa et al., 2004). Entretanto, Filgueira (2003) relata que o peso do tubérculo da batata-semente em si pouco influencia na produção. O que influencia na produção é o número de hastes por hectare.

O tamanho dos minitubérculos pode ser afetado em função da colheita ser feita de uma única vez ou de maneira escalonada. Tanto para o cv. Monalisa quanto para o cv. Ágata, na colheita única, os minitubérculos foram estatisticamente maiores. A possível explicação seria que na colheita única, os tubérculos tiveram todo o ciclo para se desenvolverem, ao passo que na colheita escalonada, o prazo para o crescimento é limitado, cerca de 15 dias entre uma colheita e outra (Corrêa et al., 2004). Esses resultados obtidos por Corrêa et al. (2004), para o número de tubérculos maior que 2 $\mathrm{cm}$, observaram efeito linear do número de plantas por vaso para esta variável. Com uma planta, cada vaso produziu em média 9 minitubérculos. 0 número de minitubérculos aumentou linearmente até 5 plantas por vaso, onde se obteve aproximadamente 17 tubérculos por vaso em média.

\subsubsection{Peso do material seco}

$O$ peso do material seco na parte aérea foi significativo $(P<0,01)$ e ajustou-se melhor ao modelo de regressão linear (Figura 10). Observou-se que o peso do material seco obtido na parte aérea apresentou um aumento constante, para $X \in[2 ; 7]$. O peso do material seco na parte aérea aumentou a cada semana $(X)$ aproximadamente $1,30 \mathrm{~g}$ $(\mathrm{Y})$.

No entanto, não foi atingido o valor máximo do peso do material seco na parte aérea das plantas em função da colheita realizada aos 53 DAT, período em que as plantas estavam entrando em processo de senescência. 


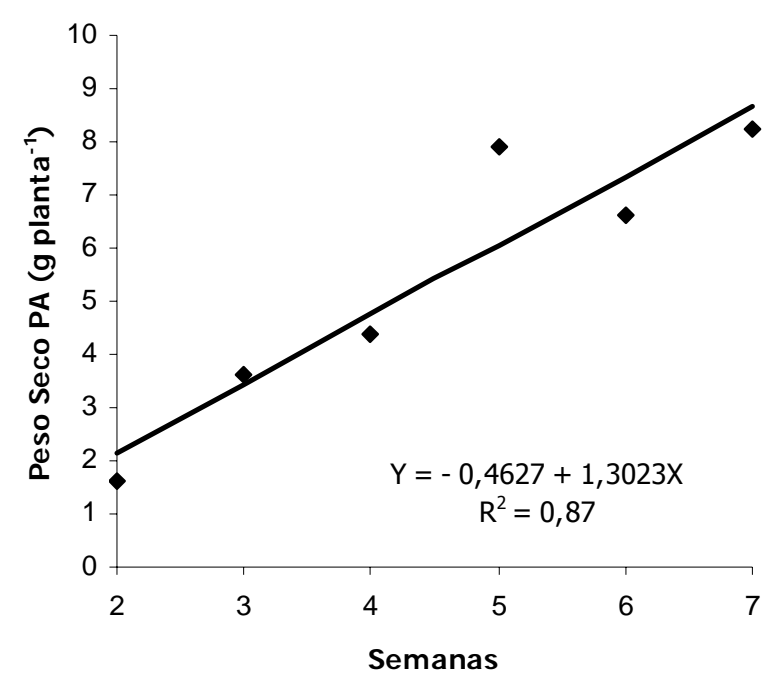

Figura 10 - Peso do material seco na parte aérea (g planta ${ }^{-1}$ ) para os tratamentos

O peso do material seco na parte aérea atingiu o maior valor na semana 7, aos 53 DAT e foi de $8,65 \mathrm{~g}_{\text {planta }}{ }^{-1}$. No entanto, o ponto máximo do peso do material seco na parte aérea não foi atingido pela planta nos tratamentos. Observou-se uma relação positiva entre o peso do material seco na parte aérea e o peso do material seco nos minitubérculos obtidos para os tratamentos.

Quanto às folhas, Yorinori (2003), em pivô central, com o cv Atlantic, observou um aumento contínuo até 69 DAP, seguido de um período de pequeno aumento, até os $79 \mathrm{DAP}$, quando ocorreu o acúmulo máximo de 22,67 $\mathrm{g}_{\text {planta }}{ }^{-1}$. Após este período ocorreu um decréscimo pequeno até 95 DAP, seguido de uma queda brusca até o final do ciclo.

O peso do material seco determinado nas raízes das plantas não diferiu para os tratamentos. Portanto, não se aplicou modelo de regressão e não foi representado em figura. Plantas provenientes de cultura de tecidos apresentam um sistema radicular menos vigoroso quando comparado com plantas obtidas a partir de tubérculos sementes, as quais apresentam um sistema radicular mais desenvolvido.

$O$ peso do material seco nos minitubérculos foi significativo $(P<0,01)$ e ajustou-se melhor ao modelo de regressão linear (Figura 11). Observou-se que o peso do material seco nos minitubérculos apresentou um aumento constante, para $X \in[2$; 
7]. O peso do material seco nos minitubérculos aumentou a cada semana ( $X$ ) aproximadamente $1,00 \mathrm{~g}(\mathrm{Y})$.

O peso do material seco nos minitubérculos produzidos não atingiu um ponto máximo, porém o maior valor obtido foi de $3,40 \mathrm{~g}$ planta $^{-1}$ na última coleta aos 53 DAT. A formação de minitubérculos seguindo a diferenciação dos estolhos manifestou-se de forma mais definida na semana 4 aos 32 DAT. O enchimento dos minitubérculos ocorreu de forma contínua até a semana 6 aos 46 DAT, aumentando de forma expressiva a produção de material seco entre a semana 6 e a semana 7 .

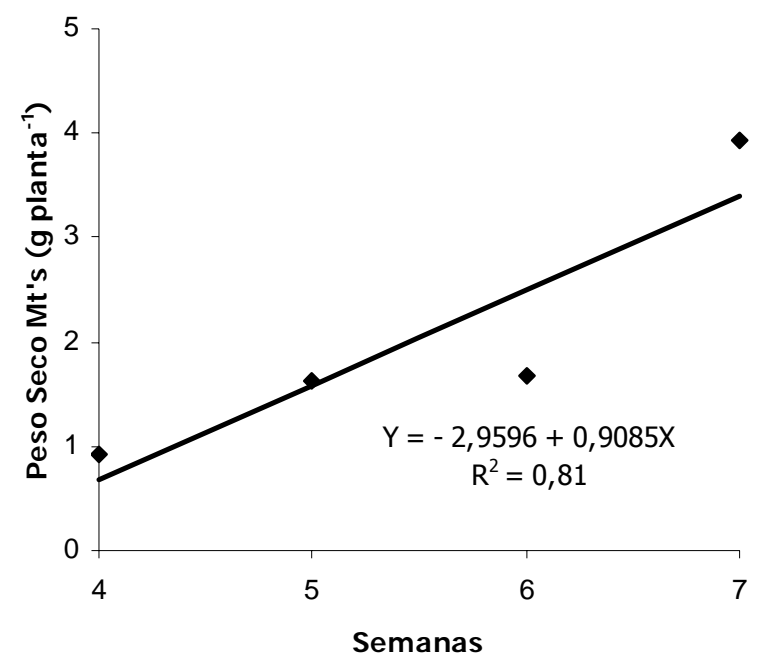

Figura 11 - Peso do material seco (g) nos minitubérculos por planta para os tratamentos

Observou-se uma relação positiva referente ao peso do material seco nos minitubérculos e ao acúmulo do peso do material seco na parte aérea das plantas. Para essas variáveis estudadas foi verificado um aumento contínuo para os tratamentos.

Do início da tuberização até o seu final, o peso dos tubérculos aumenta linearmente; nesta fase pode haver produção de 400 a $700 \mathrm{~kg}$ de tubérculos ha ${ }^{-1} \mathrm{dia}^{-1}$, dependendo da cultivar, da época do ano e do manejo da cultura. A produção de tubérculos é determinada pela fotossíntese, respiração e partição dos assimilados para os tubérculos, processos ligados a fatores ambientais, genéticos e de manejo da 
cultura. Todos estes fatores que influenciam estes processos afetarão quantitativamente a tuberização (Fontes \& Finger, 1999).

$O$ peso do material seco total nas plantas foi significativo $(P<0,01)$ e ajustou-se melhor ao modelo de regressão linear (Figura 12). Observou-se um aumento constante no peso do material seco nos órgãos analisados. O sistema radicular não diferiu com relação ao peso do material seco para os tratamentos, portanto esta variável não foi apresentada separadamente como as outras variáveis na figura, enquanto que o peso do material seco na parte aérea das plantas, o peso do material seco nos minitubérculos e o peso do material seco total diferiram para os tratamentos sendo assim apresentados. O crescimento da planta apresentou-se contínuo e dinâmico, característico de planta anual.

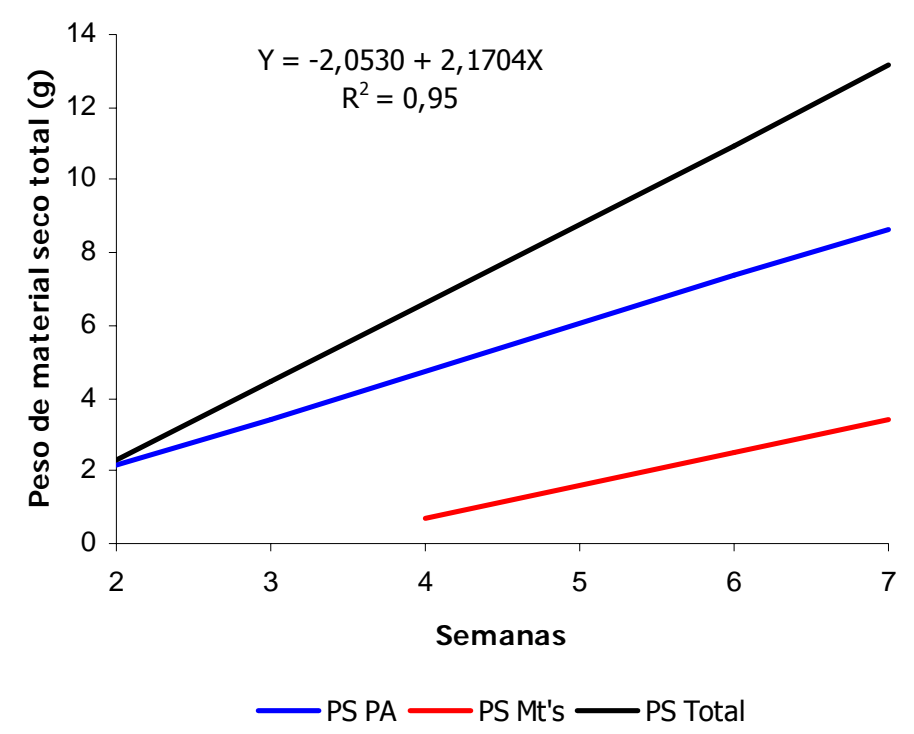

Figura 12 - Peso do material seco total por planta (g) para os tratamentos

O acúmulo de massa de material seco total na planta apresentou aumento contínuo para os tratamentos: na semana 2 e 3, de 18 a 25 DAT, período de crescimento vegetativo, o acúmulo de massa de material seco total foi de 2,29 e 4,46 g planta $^{-1}$, sendo que a porcentagem foi de 5 e 10\%; na semana 4 aos 32 DAT, fase de tuberização, foi de 6,63 $\mathrm{g} \mathrm{planta}^{-1}$, de 14\%; nas semanas 5 e 6, de 39 a 46 DAT, 
enchimento dos tubérculos, foi de 8,80 e 10,97 g planta $^{-1}$, de 19 e $24 \%$, e na semana 7 aos 53 DAT, período de maturação, foi de $13,14 \mathrm{~g}$ planta $^{-1}$, de $28 \%$.

Observou-se que a maior porcentagem do peso seco total das plantas ocorreu na semana 7 aos 53 DAT. O mesmo comportamento foi também verificado na parte aérea das plantas e nos minitubérculos. Entretanto, Yorinori (2003) verificou que o maior acúmulo de massa de material seco no cv. Atlantic foi de $5,9 \mathrm{~g} \mathrm{planta}^{-1} \mathrm{dia}^{-1}$ no período de 62 a 69 DAP.

O acúmulo de massa da planta foi influenciado pelos estádios da cultura: vegetativo $(2,2 \%)<$ tuberização $(13 \%)<$ enchimento de tubérculos $(90 \%)<$ maturação (100\%), em cv. Atlantic, determinado por Yorinori (2003).

Wolfe et al. (1983) encontraram redução na acumulação de fitomassa e na duração da área foliar, que apresentou elevada correlação com a matéria seca total final, mas não detectaram diferenças significativas na partição de assimilados.

A relação existente entre a parte aérea (caule + folhas) e a subterrânea (raízes + tubérculos) é um aspecto importante. Do plantio até a floração, a MS da parte aérea foi maior, se comparada à parte subterrânea e a partir desse ponto, ocorreu uma inversão de valores no cv. Atlantic (Yorinori, 2003). Entretanto, durante os períodos de 84 a 90 DAP e após os 97 DAP, as taxas negativas de acúmulo da parte aérea podem ser explicadas pelo translocamento de fotoassimilados e minerais da parte aérea para os tubérculos (Roberts \& Dole, 1985).

A manutenção da folhas no enchimento dos tubérculos é de extrema importância para se obter uma boa produtividade, pois é nesta fase que os fotossintatos e os nutrientes minerais são translocados para os tubérculos (Roberts \& Dole, 1985).

Contudo, vale ressaltar que a cultura da batata apresenta comportamento biológico diferente do das outras espécies vegetais relatadas pelos autores Watson (1952) e Calbo et al. (1989), pois ela acumula reservas nos tubérculos e não na parte aérea. Assim, esse padrão, acrescido da senescência e do fenecimento foliar, sugere uma maior eficiência no final do ciclo vegetativo. 


\subsection{Marcha de absorção de macronutrientes}

O consumo de nutrientes pela batata foi crescente durante os tratamentos, acompanhando o desenvolvimento das plantas e o acúmulo de matéria seca pelas mesmas. Resultados semelhantes com relação aos parâmetros de crescimento e a marcha de absorção foram encontrados na literatura, porém os obtidos no presente trabalho foram, na maioria das vezes, menos expressivos em função do sistema de cultivo ser de produção de batata-semente e não de batata-consumo e por isso apresentar ciclo mais curto, aproximadamente 60 dias, provavelmente resultados mais expressivos seriam encontrados se o ciclo fosse maior.

Estudo realizado por Fayad et al. (2000) pela cultura do tomate, cv. Carmem, pertencente à mesma família solanácea, mostraram comportamento semelhante com relação ao comportamento das plantas de batata. De forma geral, as curvas de absorção de nutrientes mostraram três fases de intensidade de consumo: nos primeiros 45 dias as plantas absorveram pouco nutriente, passando por período de intenso acúmulo dos 45 a aproximadamente 90 dias, seguido pela tendência de estabilização até a última colheita, aos 120 dias. Exceção para o $\mathrm{Ca}, \mathrm{Mg}$, Fe e $\mathrm{Mn}$ e $\mathrm{Zn}$ que apresentaram intenso acúmulo de nutrientes dos 45 aos 120 dias. O acúmulo de nutrientes no tomateiro até aproximadamente 45 dias, foi devido ao desenvolvimento das folhas, caule e primórdios florais. A partir dos 45 dias o intenso acúmulo de nutrientes deveu-se principalmente aos frutos.

\subsubsection{Nitrogênio}

$O$ acúmulo total de nitrogênio na parte aérea (PA) da cultura foi significativo $(P<0,01)$ e ajustou-se ao modelo quadrático de regressão (Figura 13).

O maior acúmulo do nitrogênio na parte aérea das plantas, ocorreu entre a semana 6 e 7 aos 47 DAT e foi de 279,41 mg planta $^{-1}$. 


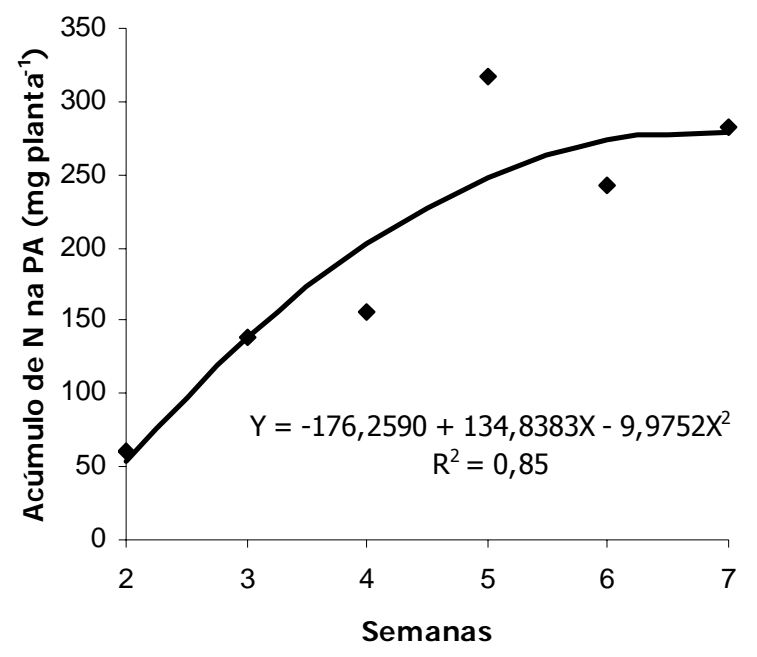

Figura 13 - Nitrogênio acumulado na parte aérea para os tratamentos ( $\mathrm{mg} \mathrm{planta}^{-1}$ )

A taxa de exportação, por ocasião da colheita, na semana 7 aos 53 DAT apresentou valores médios em porcentagem de $88 \%\left(282,07 \mathrm{mg}^{\text {planta }}{ }^{-1}\right)$ na parte aérea, $6 \%\left(19,11 \mathrm{mg}\right.$ planta $\left.{ }^{-1}\right)$ nas raízes e $6 \%\left(19,15 \mathrm{mg}\right.$ planta $\left.{ }^{-1}\right)$ nos minitubérculos.

Valores diferentes de acúmulo máximo de nitrogênio foram encontrados, em condições de campo, por Paula et al. (1986) em um estudo sobre a produção de massa de material seco e a absorção de macronutrientes por cultivares de batata, verificando que a maior parte da quantidade total máxima acumulada de nitrogênio estava nos tubérculos ( $88 \%$ do $\mathrm{N}$ total nos tubérculos da cv. Achat e $80 \%$ no cv. Mantiqueira).

Bregagnoli et al. (2004), em condições de campo, mostraram o acúmulo de $\mathrm{N}$ nos tecidos aos 45 DAP tendo como teor médio no tubérculo, folha e haste, de 1,7; 5,41 e 2,09 \%, respectivamente. Similarmente, ocorreu aos 65 DAP, porém, com elevação da concentração nos tubérculos $(2,11 \%)$, diminuição nas folhas $(4,4 \%)$ e hastes $(1,38 \%)$, devido a sua translocação para os tubérculos.

A expectativa de maiores rendimentos com um baixo suprimento inicial de nitrogênio, favorecendo a tuberização, com um posterior aumento desse suprimento no período de grande demanda dos tubérculos, não foram confirmadas por Cunha \& Medeiros (2004). Este fato é devido às características do sistema hidropônico utilizado, 
no qual a colheita foi feita de forma escalonada, sendo os tubérculos retirados das plantas antes de completarem seu crescimento.

O acúmulo de nitrogênio nas raízes da cultura ajustou-se ao modelo quadrático de regressão e foi significativo $(P<0,05)$, no entanto o valor R-Quadrado foi mediano $\left(R^{2}=0,57\right)$, portanto os valores não foram apresentados graficamente.

Os valores médios encontrados indicam que a taxa de maior acúmulo de nitrogênio nas raízes ocorreu na fase vegetativa, na semana 2, aos 18 DAT e foi de $20,55 \mathrm{mg}_{\text {planta }}{ }^{-1}$. Com relação à taxa de exportação de nitrogênio na colheita, aos 53 DAT, o valor médio do acúmulo foi de $19,11 \mathrm{mg}$ planta $^{-1}$. Resultados diferentes foram obtidos por Yorinori (2003) com o cv. Atlantic nas raízes (12,47 mg planta-1).

$\mathrm{O}$ acúmulo máximo de nitrogênio nos minitubérculos ( $\left.M \mathrm{t}^{\prime} \mathrm{s}\right)$ foi significativo $(\mathrm{P}<$ 0,05) e ajustou-se ao modelo quadrático de regressão (Figura 14).

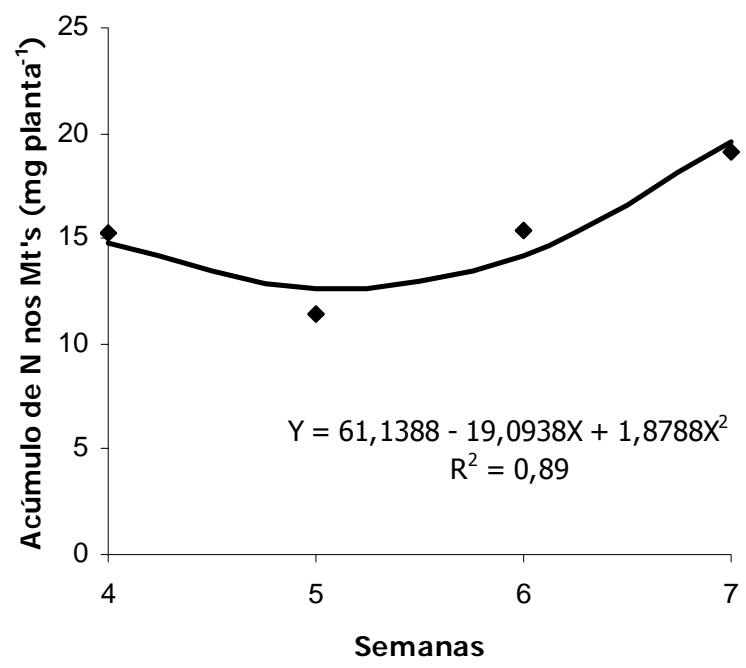

Figura 14 - Nitrogênio acumulado nos minitubérculos para os tratamentos (mg planta ${ }^{-1}$ )

O acúmulo máximo de nitrogênio nos minitubérculos ocorreu na semana 5 aos 39 DAT e foi de $12,63 \mathrm{mg}$ planta ${ }^{-1}$. Valores superiores foram encontrados por Yorinori (2003) em cv. Atlantic (81,87 mg planta $\left.{ }^{-1}\right)$ e ocorreu no período de 63 a 69 DAP.

A cultura da batata requer uma quantidade baixa de nitrogênio durante 0 crescimento vegetativo. Aproximadamente $15 \%$ do nitrogênio total, para 'Russet 
Burbank', cultivada em campo, ocorreu nesse período e sua deficiência pode ser corrigida rapidamente nessa fase, com uma adubação de cobertura seguida de irrigação (Ojala et al., 1990).

\subsubsection{Fósforo}

$O$ acúmulo de fósforo na parte aérea (PA), foi significativo $(P<0,01)$ e ajustouse ao modelo quadrático de regressão (Figura 15). O maior valor do acúmulo de fósforo obtido na parte aérea foi de $57,11 \mathrm{mg} \mathrm{planta}^{-1}$ e ocorreu na semana 7 aos 53 DAT.

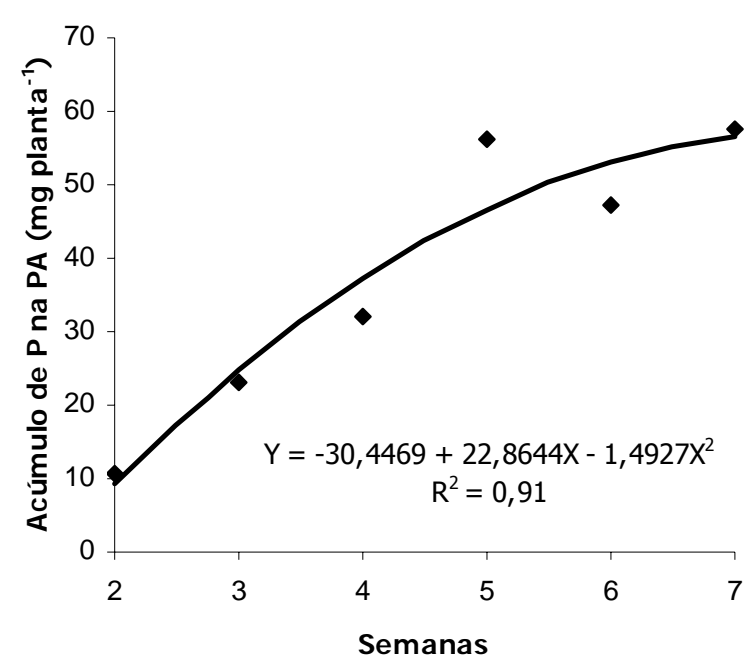

Figura 15 - Fósforo acumulado na parte aérea para os tratamentos (mg planta ${ }^{-1}$ )

A taxa de exportação de fósforo por ocasião da colheita na semana 7 aos 53 DAT apresentou valores médios de $82 \%\left(57,42 \mathrm{mg} \mathrm{planta}^{-1}\right)$ na parte aérea, $12 \%(8,52$ $\left.\mathrm{mg} \mathrm{planta}^{-1}\right)$ nas raízes e $6 \%\left(4,06 \mathrm{mg}\right.$ planta $\left.^{-1}\right)$ nos minitubérculos.

$\mathrm{O}$ acúmulo de fósforo nas raízes foi significativo $(\mathrm{P}<0,05)$ e ajustou-se ao modelo quadrático de regressão (Figura 16). O acúmulo máximo de fósforo observado foi de $6,10 \mathrm{mg}$ planta $^{-1}$ e ocorreu entre a semana 4 e 5 semana, aproximadamente aos 33 DAT. 


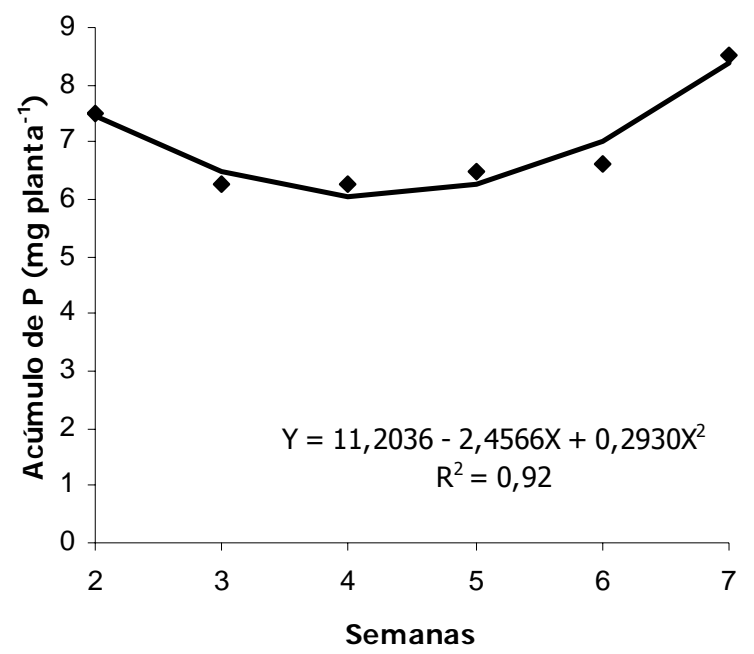

Figura 16 - Fósforo acumulado nas raízes para os tratamentos (mg planta ${ }^{-1}$ )

O valor médio obtido do acúmulo maior de fósforo nas raízes ocorreu na semana 7 aos 53 DAT e foi de 8,52 mg planta ${ }^{-1}$. Valores inferiores foram encontrados por Yorinori (2003) no cv. Atlantic (1,36 $\left.\mathrm{mg} \mathrm{planta}^{-1}\right)$ aos $61 \mathrm{DAP}$.

$O$ acúmulo de fósforo obtido nos minitubérculos foi significativo $(P<0,05)$ e ajustou-se ao modelo quadrático de regressão (Figura 17). O ponto máximo obtido foi de 4,00 mg planta ${ }^{-1}$ entre a semana 6 e 7 aos 44 DAT. Esses resultados não concordam com os reportados por Bregagnoli et al. (2004), onde aos 45 DAP o P teve tendência de se concentrar mais nas hastes e nas folhas do que nos tubérculos e aos 65 DAP, ocorreu o inverso, a maior concentração de $\mathrm{P}$ se deu nos tubérculos. Isso mostra a importância do fósforo na tuberização. 


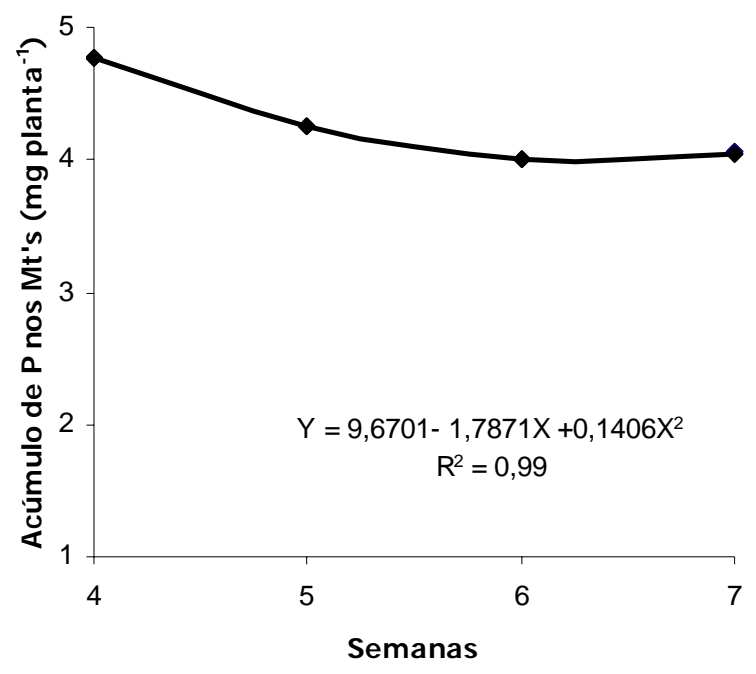

Figura 17 - Fósforo acumulado nos minitubérculos para os tratamentos (mg planta ${ }^{-1}$ )

O teor máximo de fósforo nas raízes, caules, folhas e tubérculos, independentemente da adubação ou de cultivar, ocorreu na primeira amostragem, aos 20 DAP, exceção ao teor de fósforo no tubérculo do cv. Achat quando não adubada. Em ambos os cultivares os teores máximos de fósforo ocorreram nas folhas (Paula et al., 1986). Entretanto, Gallo et al. (1965) verificaram também um aumento no teor de fósforo nas folhas com aplicação de superfosfato.

A quantidade máxima acumulada de fósforo aumentou, em ambos os cultivares, nos diversos órgãos da planta, com o uso de adubação. No cv. Achat, o aumento foi de $28 \%$ e em 'Mantiqueira', $98 \%$. Da quantidade total máxima acumulada no tratamento sem adubação, cerca de 99\% estava no tubérculo no cv. Achat e 93\% no do cv. Mantiqueira. Com a adubação, em ambos os cultivares, houve aumento da absorção total de fósforo na planta. Enquanto no cv. Mantiqueira, sem adubação, a absorção de fósforo decresceu no final do ciclo, em 'Achat' continuou a crescer (Paula et al., 1986).

As curvas de fósforo e de produção de massa de material seco apresentaram-se intimamente relacionadas, indicando que a suplementação deve ser contínua (Ezeta \& McCollum, 1972). A intensidade máxima de absorção de nitrogênio, potássio, magnésio e enxofre ocorrem normalmente entre 40 e 50 dias após a emergência; por outro lado, 
fósforo e cálcio são absorvidos continuamente até 80 dias após a emergência (Furumoto \& Lopes, 1997). Esses dados confirmam os dados obtidos neste experimento, onde ocorreu um acúmulo máximo de fósforo na mesma época e comportamento apresentado pelo $\mathrm{P}$ e Ca mostrou absorção contínua para os tratamentos.

Os resultados obtidos com o cv. Atlantic mostram que o maior acúmulo de fósforo na parte aérea, raízes e mini-tubérculos ocorreram, respectivamente, aos 53, 53 e 32 DAT. Resultados diferentes foram obtidos por Yorinori (2003), indicando que a taxa maior de acúmulo de fósforo nas raízes ocorreu durante o crescimento vegetativo de 20 a 27 DAP e nos caules e folhas, na tuberização de 42 a 48 e 34 a 41 DAP, respectivamente e nos tubérculos, no enchimento de tubérculos de 63 a 69 DAP.

\subsubsection{Potássio}

O acúmulo de potássio na parte aérea foi significativo $(P<0,01)$ e ajustou-se ao modelo de regressão linear (Figura 18). O acúmulo de potássio na parte aérea apresentou-se de forma contínua e crescente nos tratamentos. Observou-se que o acúmulo de potássio apresentou aumento constante, para $X \in[2 ; 7]$. $O$ acúmulo de potássio na parte aérea aumentou a cada semana (X) 100,30 mg (Y).

$O$ acúmulo de potássio nas raízes foi significativo $(P<0,05)$, porém apresentou um valor mediano do $R$-Quadrado $\left(R^{2}=0,62\right)$, optando-se por não ser representado por figura.

O acúmulo de potássio nos minitubérculos para os tratamentos não foi significativo. Portanto, para essas variáveis estudadas não foram aplicados modelos de regressão. 


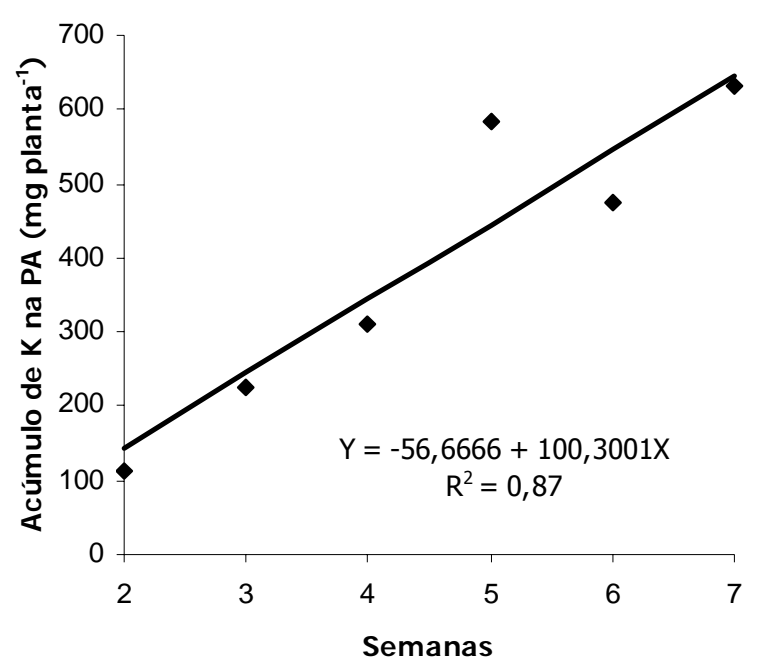

Figura 18 - Potássio acumulado na parte aérea para os tratamentos (mg planta ${ }^{-1}$ )

O maior valor obtido do potássio acumulado, na parte aérea das plantas, ocorreu na semana 7, aos 53 DAT, e foi de $645,43 \mathrm{mg}$ planta ${ }^{-1}$. Entretanto, o ponto máximo do potássio acumulado não foi verificado para esses tratamentos.

A taxa de exportação do potássio por ocasião da colheita na semana 7 aos 53 DAT apresentou valores médios em porcentagem de $92 \%\left(630,24 \mathrm{mg}_{\text {planta }}{ }^{-1}\right)$ na parte aérea, $4 \%\left(26,72 \mathrm{mg}\right.$ planta $\left.^{-1}\right)$ nas raízes e $4 \%\left(25,63 \mathrm{mg}\right.$ planta $\left.^{-1}\right)$ nos minitubérculos.

Resultados de pesquisa realizada por Reis Junior \& Monnerat (2001), mostraram que a adubação com $\mathrm{K}_{2} \mathrm{SO}_{4}$ não influenciou a produção de matéria seca de tubérculos e nem houve interação significativa entre doses de $\mathrm{K}_{2} \mathrm{SO}_{4}$ e época de amostragem. Por outro lado, a produção de matéria seca de tubérculo aumentou com o crescimento da planta, fato esse esperado. Como houve aumento significativo de produção de matéria fresca de tubérculo, mas o mesmo não aconteceu com a produção de matéria seca de tubérculos, possivelmente, o aumento das doses de $\mathrm{K}_{2} \mathrm{SO}_{4}$ favoreceu o acúmulo de água nos tubérculos

Aos 20 e 48 DAE a parte aérea foi o principal dreno para $\mathrm{K}, \mathrm{Ca}, \mathrm{Mg}, \mathrm{S}, \mathrm{Cl}$ e $\mathrm{Mn}$, e apenas próximo à colheita, os tubérculos se tornaram o principal dreno para estes nutrientes (Reis Junior \& Monnerat, 2001). Todavia, cultivares de batata que absorvem 
grandes quantidades de potássio não o convertem, necessariamente, em produção de tubérculos, indicando que altas doses de nitrogênio estão mais relacionadas com o crescimento da parte aérea (Lewis, 1989), citado por (Reis Junior \& Monnerat, 2001).

Resultados do experimento com tomate, o $\mathrm{K}$ foi o elemento mais consumido seguido pelo $\mathrm{N}, \mathrm{Ca}, \mathrm{Mg}, \mathrm{P}, \mathrm{Cu}, \mathrm{Mn}$, Fe e $\mathrm{Zn}$. Nesta mesma ordem, o dia de maior consumo destes nutrientes foram aos 66, 74, 81, 73, 66, 84, 62, 109 e 76 DAT das mudas. A curva de acúmulo de nutrientes seguiu de forma semelhante o acúmulo de matéria seca. Até o início da floração/frutificação, aproximadamente aos 45 dias, a razão K:N foi de 1,3:1; dos 45-90 dias foi de 1,3:1 e dos 90-120 foi de 0,8:1 (Fayad et al., 2000).

Segundo Paula et al. (1986), os teores máximos de potássio nos tubérculos para o cv. Mantiqueira foram obtidos no final do ciclo, enquanto que, nas folhas, os teores máximos ocorreram em épocas que variaram de 40 a 60 dias para o cv. Achat e de 60 a 80 dias para 'Mantiqueira'. A absorção de potássio decresceu no final do ciclo, com exceção para 'Achat'. No entanto, resultados obtidos neste experimento, observou-se que na última coleta a absorção de potássio não decresceu na semana 7 aos 53 DAT para o cv. Atlantic. Este comportamento mostra que há diferença de capacidade de acúmulo de potássio entre as cultivares.

A maior taxa de acúmulo de potássio nas raízes, caules e folhas ocorreu na tuberização, de 35 a 48 DAP e nos tubérculos, na maturação, dos 98 aos 104 DAP (Yorinori, 2003). Entretanto, nesse experimento o maior acúmulo na parte aérea, raízes e mini-tubérculos foi atingido aos 53, 25 e 32 DAT, respectivamente.

\subsubsection{Cálcio}

O acúmulo de cálcio na parte aérea foi significativo $(P<0,01)$ e ajustou-se ao modelo de regressão linear (Figura 19). Observou-se que o acúmulo de cálcio na parte aérea das plantas apresentou um aumento constante, para $X \in[2 ; 7]$. $O$ acúmulo de cálcio aumentou a cada semana (X) 33,45 mg (Y).

O maior valor obtido do cálcio acumulado na parte aérea das plantas foi de 186,40 mg planta ${ }^{-1}$ e ocorreu na semana 7 aos 53 DAT. No entanto, não foi observado o acúmulo máximo de cálcio na parte aérea das plantas para esses tratamentos. 


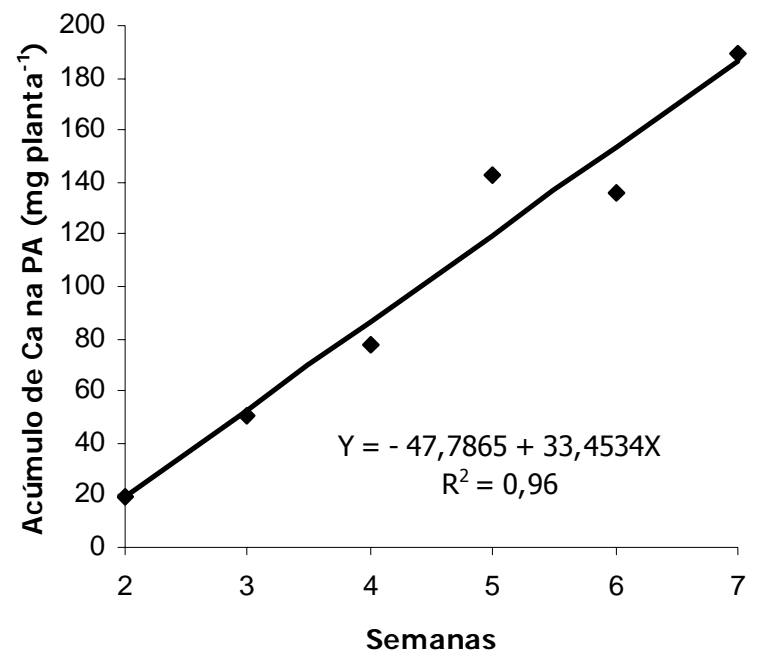

Figura 19 - Cálcio acumulado na parte aérea para os tratamentos (mg planta ${ }^{-1}$ )

O acúmulo de cálcio obtido nas raízes foi significativo $(P<0,05)$ e ajustou-se ao modelo quadrático de regressão (Figura 20). Entretanto, os valores obtidos nos minitubérculos não diferiram entre os tratamentos, portanto, não foi aplicado modelos de regressão. 


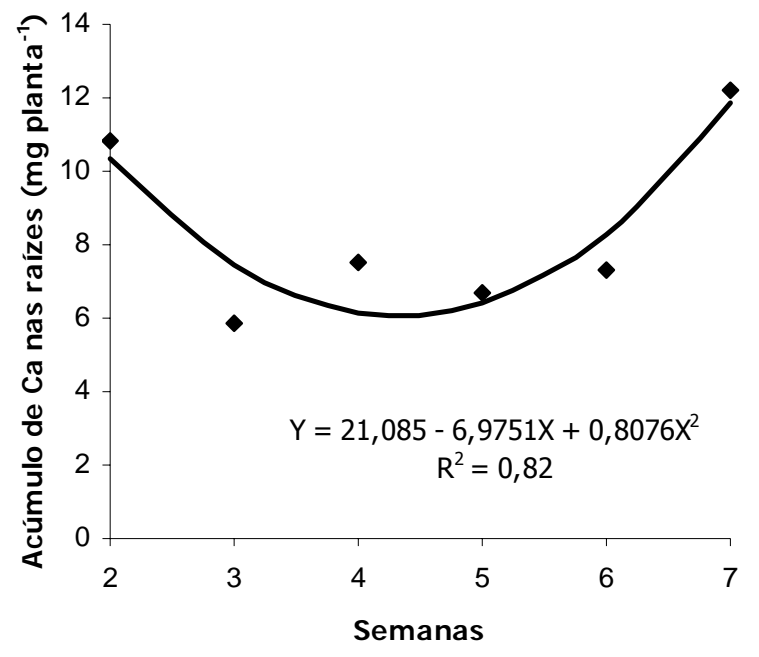

Figura 20 - Cálcio acumulado nas raízes para os tratamentos (mg planta ${ }^{-1}$ )

O acúmulo máximo de cálcio observado nas raízes das plantas ocorreu entre a semana 4 e 5 dos 32 aos 39 DAT e foi de 6,02 mg planta $^{-1}$; esse comportamento diferiu dos demais nutrientes que apresentaram maior absorção na semana 7 aos 53 DAT. Paula et al. (1986), verificaram que a absorção de cálcio decresceu no final do ciclo para os cultivares Achat e Mantiqueira.

A taxa de exportação de cálcio por ocasião da colheita na semana 7 aos 53 DAT, apresentou valores médios de $94 \%$ (189,33 $\left.\mathrm{mg} \mathrm{planta}^{-1}\right)$ na parte aérea e de $6 \%$ $\left(12,21 \mathrm{mg} \mathrm{planta}^{-1}\right)$ nas raízes das plantas, sendo que, os menores teores de cálcio foram encontrados nos minitubérculos $\left(0,18 \mathrm{mg} \mathrm{planta}^{-1}\right)$. Os teores de cálcio nos tubérculos tiveram uma amplitude de 0,01 a 0,07 (Paula et al., 1986).

Os teores máximos de cálcio na raiz, caule e folha nos dois cultivares ocorreram no final do ciclo. Este aumento de concentração de cálcio no final do ciclo na raiz e parte aérea pode evidenciar a pouca mobilidade e baixa translocação deste nutriente para o tubérculo na $1^{\mathrm{a}}$ amostragem. Os teores máximos mais elevados apareceram nas folhas, seguidas do caule, raízes e tubérculos. Os teores mínimos de cálcio nas folhas ocorreram na primeira amostragem, e nos tubérculos no final do ciclo (Paula et al., 1986), concordando com os valores obtidos neste experimento. 
Sendo o cálcio pouco móvel, sua difusão das lenticelas para os tecidos mais internos é dificultada, pouco contribuindo para elevação dos teores deste nutriente nos tecidos mais internos do tubérculo (Paiva et al.,1997). Observaram, ainda, um aumento nos teores de cálcio na folha à medida que aumentou o teor de cálcio na solução nutritiva. Entretanto, a taxa de acréscimo foi sendo reduzida nos tratamentos de maior nível de cálcio na solução o que indica haver uma barreira à absorção de cálcio acima de certo nível, possivelmente em decorrência da endoderme nas raízes. A limitação à absorção imposta pela endoderme tem levado alguns autores a sugerir que o cálcio seja preferencialmente absorvido nas extremidades das raízes.

Yorinori (2003), observou que o acúmulo maior de cálcio ocorreu nas folhas, evidenciando o fato do cálcio absorvido pela raiz ser translocado para a parte aérea e não ser redistribuído dentro da planta, devido a sua baixa mobilidade. O acúmulo máximo de cálcio total foi de $521,5 \mathrm{mg}$ planta $^{-1}$ aos $92 \mathrm{DAP}$, sendo que o máximo acúmulo de cálcio total ocorreu no enchimento dos tubérculos. Por outro lado, resultados obtidos por Bregagnoli et al. (2004), mostraram que o cálcio foi uniforme em todos os tratamentos e épocas, demonstrando baixo acúmulo nos tubérculos, como de $0,175 \%$ aos 45 DAP e $0,06 \%$ aos 65 DAP.

\subsubsection{Magnésio}

$O$ acúmulo de magnésio na parte aérea da cultura foi significativo $(P<0,01)$ e ajustou-se ao modelo de regressão linear (Figura 21). Observou-se que o acúmulo de magnésio na parte aérea das plantas apresentou um aumento constante, para $X \in[2$; 7]. $O$ acúmulo de magnésio aumentou a cada semana ( $X) 10,70 \mathrm{mg}(Y)$.

O acúmulo de magnésio obtido nas raízes não foi significativo, não diferindo entre os tratamentos e o mesmo comportamento ocorreu nos minitubérculos, portanto, para estas variáveis estudadas não foram aplicados modelos de regressão. 


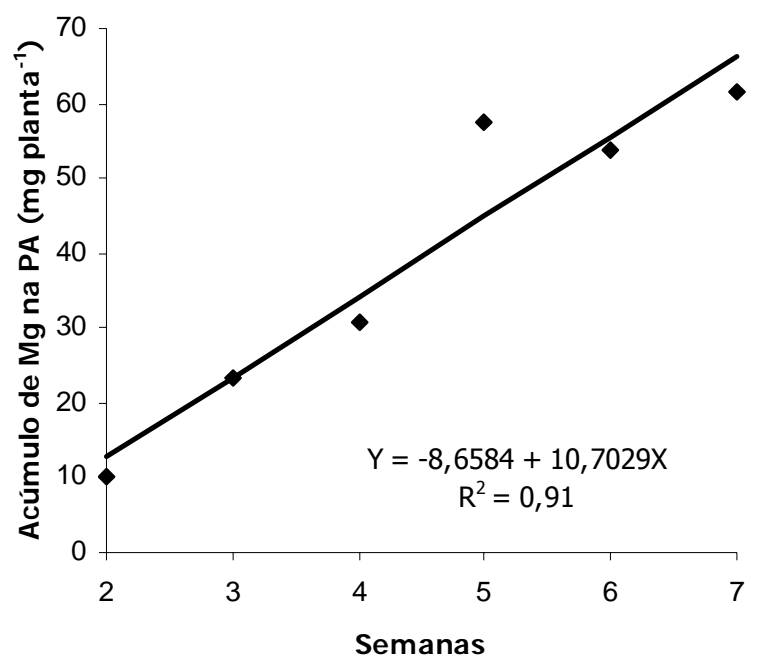

Figura 21 - Magnésio acumulado na parte aérea para os tratamentos ( $\mathrm{mg}$ planta ${ }^{-1}$ )

O maior acúmulo de magnésio ocorreu na semana 7 aos 53 DAT e foi de 66,26 mg planta ${ }^{-1}$. No entanto, o acúmulo máximo de magnésio pela parte aérea das plantas não foi observado para esses tratamentos.

A taxa de exportação de magnésio pela colheita na semana 7 aos 53 DAT apresentou valores médios de $93 \%\left(61,47 \mathrm{mg} \mathrm{planta}^{-1}\right)$ na parte aérea, 6\% (3,50 mg planta $\left.^{-1}\right)$ nas raízes e apenas $1 \%\left(0,90 \mathrm{mg} \mathrm{planta}^{-1}\right)$ encontrado nos minitubérculos.

Os teores máximos de magnésio na raiz, caule e folhas nos cultivares Achat e Mantiqueira ocorreram dos 60 aos 100 DAP. As concentrações de magnésio ocorreram no caule, seguido de folhas e raízes para o cv. Achat; enquanto que, para 'Mantiqueira', as folhas apresentaram teores mais altos de magnésio do que do caule. No 'Achat' $97 \%$ e $82 \%$ do $\mathrm{Mg}$ acumulado estavam nos tubérculos. A absorção do magnésio decresceu no final do ciclo com exceção do 'Achat' (Paula et al., 1986).

Na máxima produção, as eficiências de absorção de nutrientes pelos tubérculos (percentagem do nutriente aplicados ao solo que é exportado no tubérculo) de $\mathrm{N}$; $\mathrm{P} ; \mathrm{K}$; Ca; Mg; S e Zn foram de 49,5\%; 6,0\%; 40,4\%; 0,3\%; 36,1\%; 1,2\% e 3,4\%, respectivamente (Reis Júnior \& Monnerat, 2001).

Resultados obtidos por Yorinori (2003), mostraram que o acúmulo máximo de magnésio nas raízes, caules e folhas ocorreu no estádio de enchimento de tubérculos, 
com única exceção para os caules, que ocorreu na maturação; a taxa de maior acúmulo de magnésio nos tubérculo foi de $1,37 \mathrm{~kg} \mathrm{ha}^{-1}$, de 98 a 104 DAP. Valores superiores de $3,23 \mathrm{~kg} \mathrm{ha}^{-1}$ foram obtidos pelo cv. Green Mountain, de 92 a 101 DAP (Hawkins, 1946).

Além dos teores absolutos desse nutriente é também importante a relação Ca:Mg, devendo a mesma estar na faixa de 3 a 5:1 (Magalhães, 1985). Nesse estudo a relação Ca:Mg foi de 3:1. A literatura contém muitas referências ao "antagonismo" entre $\mathrm{Mg}$ e Ca de um lado e Mg e K do outro, sendo que o aumento na concentração de um elemento no meio implica na diminuição de absorção de outro; o efeito pode ser tão severo que o excesso da absorção de um elemento pode causar deficiência de outro. Um excesso de $\mathrm{Mg}$ pode causar falta de $\mathrm{K}$ ou, principalmente de Ca (Malavolta, 1980).

\subsubsection{Enxofre}

$\mathrm{O}$ acúmulo de enxofre na parte aérea foi significativo $(P<0,01)$ e ajustou-se ao modelo quadrático de regressão (Figura 22). O acúmulo máximo de enxofre foi de 22,37 $\mathrm{mg}^{\text {planta }}{ }^{-1}$ na semana 7 aos 53 DAT.

O acúmulo de enxofre nas raízes e nos minitubérculos não foi significativo, não diferindo entre os tratamentos. Portanto, para estas variáveis estudadas não foram aplicados modelos de regressão.

A taxa de exportação pela colheita ocorrida na semana 7 aos 53 DAT apresentou valores médios de $84 \%$ (22,29 mg planta $\left.{ }^{-1}\right)$ na parte aérea, $11 \%$ (2,94 mg planta $\left.^{-1}\right)$ nas raízes e apenas $5 \%\left(1,23 \mathrm{mg} \mathrm{planta}^{-1}\right)$ nos minitubérculos. 


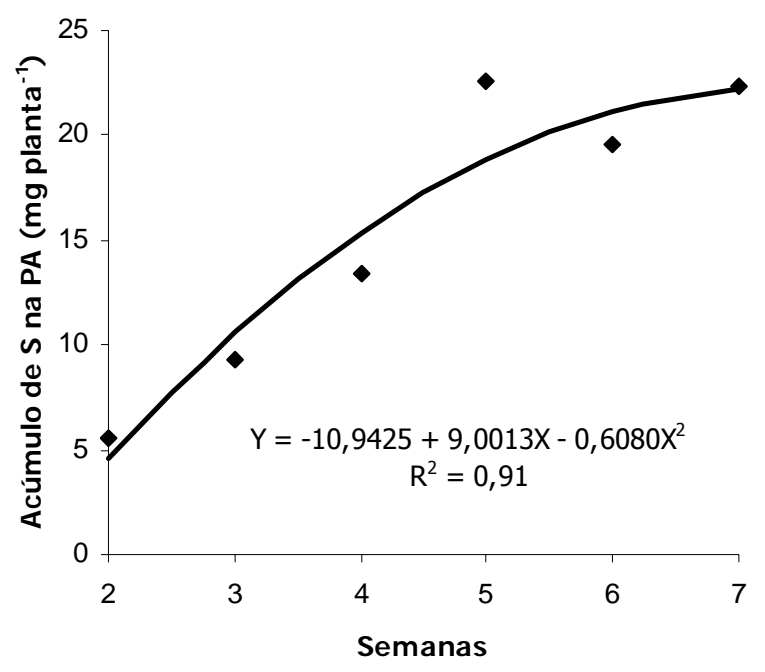

Figura 22 - Enxofre acumulado na parte aérea para os tratamentos (mg planta ${ }^{-1}$ )

A exportação de enxofre verificado por Yorinori (2003) foi de $81 \%$ do acúmulo máximo total. Paula et al. (1986) observou que do total máximo de enxofre acumulado, os tubérculos de 'Mantiqueira' continham $79 \%$ enquanto que os tubérculos de 'Achat' $88 \%$.

O teor máximo de enxofre nas folhas ocorreu dos 40 aos 60 DAP para 'Mantiqueira' e 'Achat'. O caule apresentou os maiores e os tubérculos os menores teores máximos de enxofre. A absorção de enxofre foi continua até o final do ciclo, sendo que a taxa de absorção foi máxima aos 53 DAP para 'Mantiqueira', enquanto que, para 'Achat foi atingida aos 49 DAP (Paula et al., 1986).

O acúmulo máximo de enxofre nas raízes, caules, folhas e tubérculos ocorreu aos $67 ; 74 ; 71$ e 111 DAP e foi de 1,$72 ; 26,07 ; 71,98$ e 211,97 mg planta $^{-1}(0,07 ; 1,09$; 3,00 e $8,83 \mathrm{~kg} \mathrm{ha}^{-1}$ ), respectivamente (Yorinori, 2003). Resultados obtidos por Paula et al. (1986) com os cvs. Achat (0,034;0,08; 0,18 e 2,25 kg ha-1) e Mantiqueira (0,061; 0,$24 ; 0,63$ e $3,63 \mathrm{~kg} \mathrm{ha}^{-1}$ ) de enxofre referentes a raízes, caules, folhas e tubérculos, foram inferiores.

O acúmulo máximo de enxofre na parte aérea ocorreu aos 53 DAT, comportamento semelhante pelo cv. Atlantic foi verificado por Yorinori (2003), onde a taxa de maior acúmulo de enxofre nos caules e folhas ocorreu no início do enchimento 
de tubérculos, de 49 a 55 DAP, já nas raízes, na metade da mesma fase, de 70 a 76 DAP e nos tubérculos, na maturação, de 91 a 97 DAP. O acúmulo máximo de enxofre total foi de $26,46 \mathrm{mg}$ planta-1 aos $53 \mathrm{DAP}$, valor inferior ao acúmulo máximo de enxofre total de 260,6 mg planta $^{-1}$ aos 111 DAP, em contrapartida, os valores acumulados de enxofre nas raízes obtidos aos 53 DAT são superiores aos valores encontrados por Yorinori (2003) em torno de 53 DAP.

De modo geral, o maior acúmulo dos macronutrientes pela parte aérea das plantas foi observado na semana 7 aos 53 DAT, sendo que para as raízes das plantas esse comportamento não foi significativo para a maioria dos macronutrientes nos tratamentos, exceto para o fósforo e para o cálcio, que apresentaram maior acúmulo entre a semana 4 e 5.

Entretanto, para os minitubérculos o maior acúmulo dos macronutrientes observado nos tratamentos também não foi significativo, exceto para o nitrogênio e para o fósforo, que ocorreu na semana 5 e entre a semana 6 e 7 respectivamente.

\subsection{Marcha de absorção de micronutrientes}

\subsubsection{Boro}

$O$ acúmulo de boro na parte aérea foi significativo $(P<0,01)$ e ajustou-se ao modelo de regressão linear (Figura 23). Observou-se que o acúmulo de boro na parte aérea apresentou um aumento constante, para $X \in[2 ; 7]$. $O$ acúmulo de boro aumentou a cada semana (X) 148,88 mg (Y). 


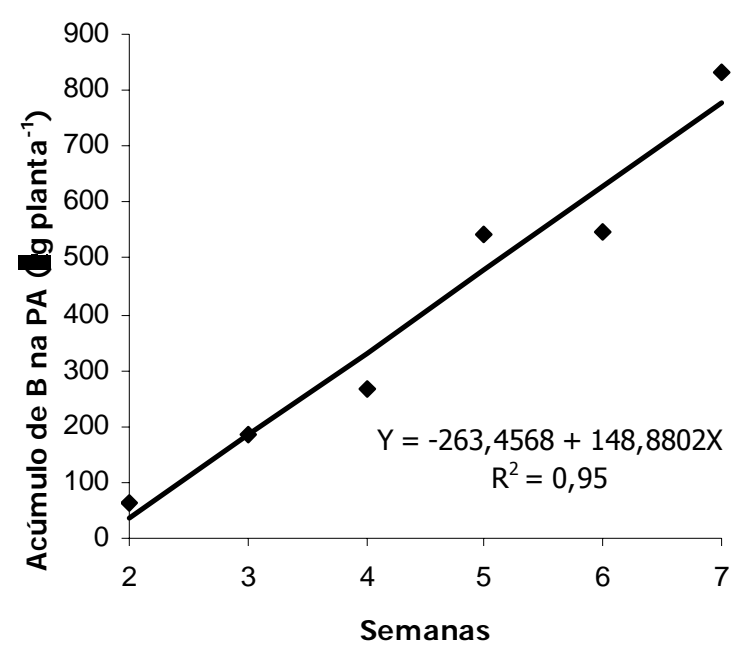

Figura 23 - Boro acumulado na parte aérea para os tratamentos ( $\mu \mathrm{g} \mathrm{planta}^{-1}$ )

O maior acúmulo de boro na parte aérea ocorreu na semana 7 aos 53 DAT e foi de $778,70 \mu \mathrm{g}$ planta ${ }^{-1}$. No entanto, o acúmulo máximo de boro na parte aérea não foi atingido para esses tratamentos.

A taxa de exportação de boro pela colheita ocorrida na semana 7 aos 53 DAT apresentou valores médios de $95 \%\left(832,64 \mu \mathrm{g}_{\text {planta }}{ }^{-1}\right)$ na parte aérea, $2 \%(17,24 \mu \mathrm{g}$ planta $\left.^{-1}\right)$ nas raízes e apenas $3 \%\left(28,70 \mu\right.$ planta $\left.^{-1}\right)$ nos minitubérculos.

$\mathrm{O}$ acúmulo máximo obtido pelos valores médios de boro pelo cv. Atlantic, na parte aérea, ocorreu aos 53 DAT e foram de $832,64 \mu$ planta $^{-1}$, enquanto que, nas raízes os valores obtidos não diferiram entre si nos tratamentos. Resultados obtidos por Yorinori (2003) apresentaram valores semelhantes com relação ao caule e folhas de 298,78 e $644,65 \mu \mathrm{g}$ planta $^{-1}$, comparados com a parte aérea, porém em períodos distintos aos 40 e 88 DAP.

Paula et al. (1986) verificaram que os maiores teores de boro ocorreram nas folhas e caule e os menores nos tubérculos. Os cultivares Achat e Mantiqueira apresentaram teores foliares de $B$ mais elevados, pois em solo mineral este nutriente se encontra mais disponível. No cv. Mantiqueira verificaram um ligeiro aumento nos teores médios de boro na raiz (2\%), caule $(7 \%)$ e folha $(15 \%)$ e no cv. Achat um ligeiro decréscimo nos mesmos na raiz $(8 \%)$, caule $(6 \%)$ e folha $(4 \%)$. 
Os teores de boro em folhas maduras no estádio inicial de desenvolvimento oscilam entre $30-40 \mathrm{mg} \mathrm{kg}^{-1}$ na matéria seca e níveis acima de $200 \mathrm{mg} \mathrm{kg}^{-1}$ podem ser considerados excessivos ou tóxicos (Fontes, 1987).

Hiroce et al. (1971), em ensaios de campo, obtiveram correlações significativas entre teores de boro nas folhas e a produção de tubérculos. Assim, enquanto que, a adubação com macronutrientes proporcionou uma produção de 6,4 $\mathrm{t} \mathrm{ha}^{-1}$ e um teor de boro nas folhas de ordem de $14 \mathrm{mg} \mathrm{kg}^{-1}$, com adição de boro àqueles, a produção passou para $16,4 \mathrm{t} \mathrm{ha}^{-1} \mathrm{e}$ o teor de boro nas folhas subiu para $23 \mathrm{mg} \mathrm{kg}^{-1}$.

O acúmulo de boro obtido nas raízes não foi significativo, não diferindo entre os tratamentos, portanto os valores obtidos não foram demonstrados por figura. Entretanto, o acúmulo de boro nos minitubérculos para os tratamentos foi significativo $(P<0,05)$ e ajustou-se ao modelo de regressão linear (Figura 24).

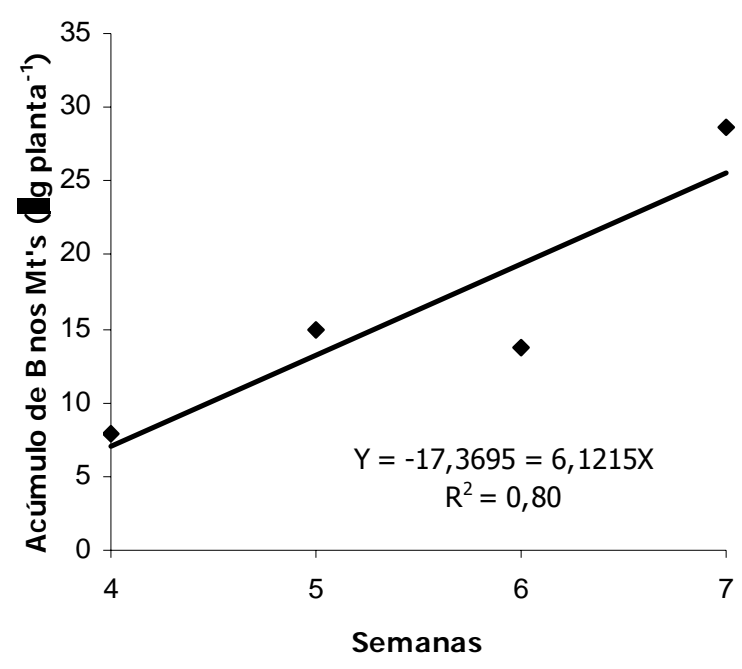

Figura 24 - Boro acumulado nos minitubérculos para os tratamentos ( $\mu \mathrm{g} \mathrm{planta}^{-1}$ )

De acordo com os valores obtidos, observou-se que o acúmulo de boro nos míni-tubérculos apresentaram um aumento constante, para $X \in[2 ; 7]$. $O$ acumulo de boro aumentou a cada semana (X) 6,12 mg (Y).

Nos minitubérculos, valores médios indicam que o maior acúmulo de boro coincidiu com o período de colheita aos 53 DAT, apresentando um acúmulo contínuo nos tratamentos. O maior acúmulo de boro nos minitubérculos ocorreu na semana 7 
aos 53 DAT e foi de $25,48 \mu \mathrm{g}$ planta $^{-1}$. No entanto o acúmulo máximo de boro nos minitubérculos não foi observado para esses tratamentos.

É interessante salientar o quanto baixo são as percentagens de cálcio e boro nos tubérculos em relação à planta toda. Cerca de $90 \%$ destes elementos permanecem na parte aérea. Dada a imobilidade do cálcio e boro é bom enfatizar a importância da disponibilidade destes nutrientes na fase de formação dos tubérculos, principalmente quando se trata de produção de batata-semente (Magalhães, 1985).

Resultados obtidos por Paula et al, (1986) verificaram que nos cultivares Achat e Mantiqueira, a adubação acarretou ligeiro decréscimo no teor médio de boro nos tubérculos. No entanto, nas primeiras amostragens a maior parte do boro acumulou-se nas folhas e nas últimas nos tubérculos, assim aos 100 DAP, $13 \%$ nas folhas e $78 \%$ nos tubérculos.

A taxa de maior acúmulo de boro nas raízes ocorreu na fase de crescimento vegetativo, da emergência até 20 DAP, nos caules, na tuberização, de 20 a 27 DAP, nas folhas e tubérculos, no enchimento dos tubérculos, de 35 a 41 e de 49 a 55 DAP (Yorinori, 2003). Nos tubérculos, os valores médios indicam que a taxa de maior acúmulo de boro do cv. Atlantic coincidiu com o período de maior produção de minitubérculos, pela mesma cultivar, que ocorreu na colheita aos 53 DAT.

\subsubsection{Cobre}

$\mathrm{O}$ acúmulo de cobre na parte aérea foi significativo $(\mathrm{P}<0,05)$ e ajustou-se ao modelo quadrático de regressão. 0 maior acúmulo de cobre ocorreu entre a semana 6 e 7 aos 47 DAT e foi de $41,52 \mu$ planta $^{-1}$. Porém, o valor do R-Quadrado obtido foi mediano $\left(R^{2}=0,59\right)$ e, portanto os valores obtidos não foram representados por figura.

O acúmulo de cobre nas raízes não foi significativo $(P<0,05)$, os valores obtidos não diferiram entre os tratamentos. Entretanto, para os minitubérculos (Mt's) os valores obtidos foram significativos $(P<0,05)$ e ajustaram-se ao modelo quadrático de regressão (Figura 25). Houve maior acúmulo entre a semana 4 e 5 aos 32 DAT e foi de $8,41 \mu \mathrm{g}$ planta ${ }^{-1}$. 


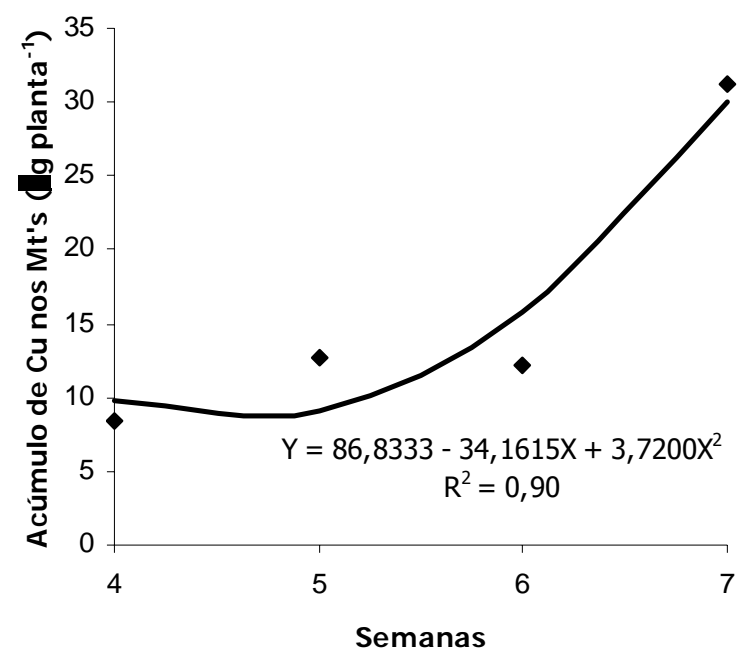

Figura 25 - Cobre acumulado nos minitubérculos para os tratamentos ( $\mu \mathrm{g} \mathrm{planta}^{-1}$ )

A taxa de exportação de cobre obtida pelos valores médios, pela colheita na semana 7 , aos 53 DAT foi de $57 \%\left(57,31 \mu \mathrm{g} \mathrm{planta}^{-1}\right)$ na parte aérea, seguida de $12 \%$ $\left(12,20 \mu\right.$ planta $\left.^{-1}\right)$ nas raízes e $31 \%\left(31,21 \mu\right.$ planta $\left.^{-1}\right)$ nos minitubérculos. $O$ valor médio do acúmulo máximo de cobre total obtido na colheita aos 53 DAT foi de 100,72 $\mu \mathrm{g}$ planta ${ }^{-1}$.

Paula et al. (1986) verificaram que os tubérculos exportaram as maiores quantidades de $\mathrm{Cu}$. Nos cv. Mantiqueira houve aumento no acúmulo total de cobre pelas plantas. Nas primeiras amostragens, a maior parte do cobre acumulou-se nas folhas e nas últimas nos tubérculos. Assim, no cv. Mantiqueira, aos $20 \mathrm{DAP}, 80 \%$ do total acumulado estava nas folhas e aos 100 DAP, $11 \%$ nas folhas e $75 \%$ nos tubérculos. A taxa de acúmulo de cobre, $526 \mathrm{mg} \mathrm{ha}^{-1} \mathrm{dia}^{-1}$, do cv. Mantiqueira, foi máxima aos 58 DAP.

O acúmulo de cobre observado por Yorinori (2003) nas raízes, nos caules e nas folhas pelo cv. Atlantic ocorreu aos 111, 85 e 80 DAP e os valores obtidos foram de 10,$93 ; 69,98$ e $288,65 \mu \mathrm{g}$ planta ${ }^{-1}$, respectivamente. A taxa de maior acúmulo de cobre nas raízes e caules ocorreram no enchimento dos tubérculos, de 56 a 62 e de 84 a 90 DAP, respectivamente e nas folhas e tubérculos, na maturação, de 98 a 104 DAP. 


\subsubsection{Ferro}

$\mathrm{O}$ acúmulo de ferro na parte aérea foi significativo $(\mathrm{P}<0,01)$ e ajustou-se ao modelo de regressão linear (Figura 26). Observou-se que o acúmulo de ferro na parte aérea apresentou um aumento constante, para $X \in[2 ; 7]$. 0 acúmulo de ferro aumentou a cada semana (X) 235,30 mg (Y).

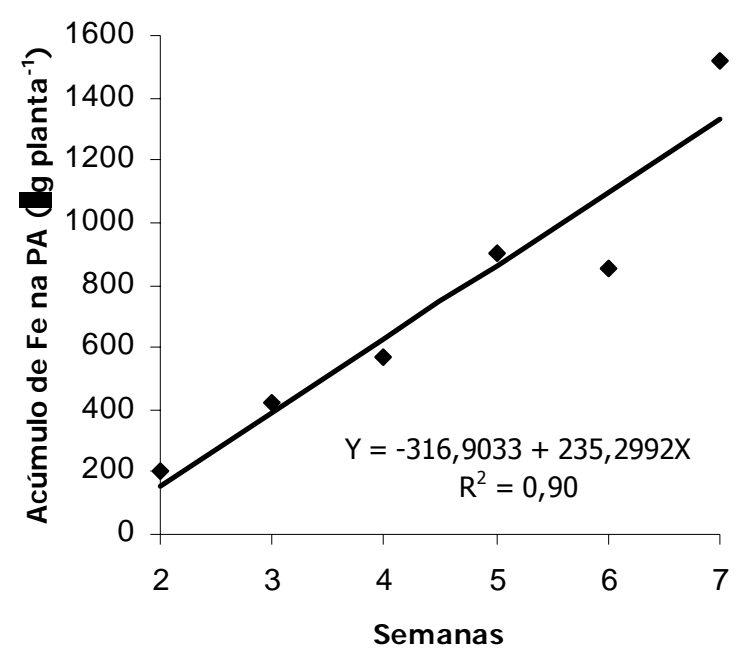

Figura 26 - Ferro acumulado na parte aérea para os tratamentos ( $\mu \mathrm{g} \mathrm{planta}^{-1}$ )

O maior valor obtido pelo acúmulo de ferro na parte aérea das plantas foi de 1330,20 e ocorreu na semana 7 aos 53 DAT. No entanto, o acúmulo máximo de ferro na parte aérea das plantas não foi observado para esses tratamentos.

A taxa de exportação de ferro obtida pela colheita na semana 7 aos 53 DAT apresentou valores médios de $80 \%\left(1521,60 \mu\right.$ planta $\left.^{-1}\right)$ na parte aérea, seguida de $15 \%\left(272,90 \mu \mathrm{g} \mathrm{planta}^{-1}\right)$ nas raízes e $5 \%\left(99,92 \mu \mathrm{g}_{\text {planta }}{ }^{-1}\right)$ nos minitubérculos. 0 valor médio do acúmulo máximo de ferro total pelas plantas obtido na colheita aos 53 DAT foi de $1894,42 \mu \mathrm{g}$ planta ${ }^{-1}$.

O acúmulo de ferro na parte aérea das plantas apresentou comportamento semelhante nos minitubérculos entre os tratamentos, os valores médios indicam que os maiores teores foram obtidos na colheita aos 53 DAT, com exceção das raízes que 
apresentou o maior acúmulo de ferro ao 46 DAT.

$\mathrm{O}$ acúmulo de ferro obtido nas raízes das plantas foi significativo $(\mathrm{P}<0,05)$ e ajustou-se ao modelo de regressão linear, porém o valor obtido pelo R-Quadrado foi mediano $\left(R^{2}=0,66\right)$ e, portanto, os valores obtidos não foram representados por figura.

O acúmulo de ferro obtido nos minitubérculos das plantas não foi significativo, não diferindo entre si nos tratamentos. Portanto, os valores obtidos não foram ajustados aos modelos de regressão.

Resultados obtidos por Paula et al. (1987), observaram que os maiores teores de ferro ocorreram nas raízes e os menores nos tubérculos dos cvs. Achat e Mantiqueira. No cv. Mantiqueira o acúmulo de ferro mostrou tendência a crescer com o desenvolvimento da planta; passou dos $291 \mathrm{mg} \mathrm{ha}^{-1}$ aos 20 DAP para $452 \mathrm{mg} \mathrm{ha}^{-1}$ aos 90 DAP. Em contrapartida, o acúmulo no cv. Achat, mostrou tendência decrescente ao longo do ciclo; passou de $345 \mathrm{mg} \mathrm{ha}^{-1}$ aos 40 DAP para $143 \mathrm{mg} \mathrm{ha}^{-1}$ aos 100 DAP.

Valores superiores foram encontrados por Yorinori (2003), o acúmulo máximo de ferro obtido nas raízes, caules e folhas ocorreu aos 65, 111 e 111 DAP e foi de $1,301,02 ; 3,613,55$ e $15.565,72 \mu \mathrm{g}$ planta $^{-1}$, respectivamente.

\subsubsection{Manganês}

$\mathrm{O}$ acúmulo de manganês na parte aérea foi significativo $(P<0,01)$ e ajustou-se ao modelo de regressão linear (Figura 27). Observou-se que o acúmulo de manganês na parte aérea apresentou aumento constante, para $X \in[2 ; 7]$. $O$ acúmulo de manganês aumentou a cada semana (X) 183,92 mg (Y). 


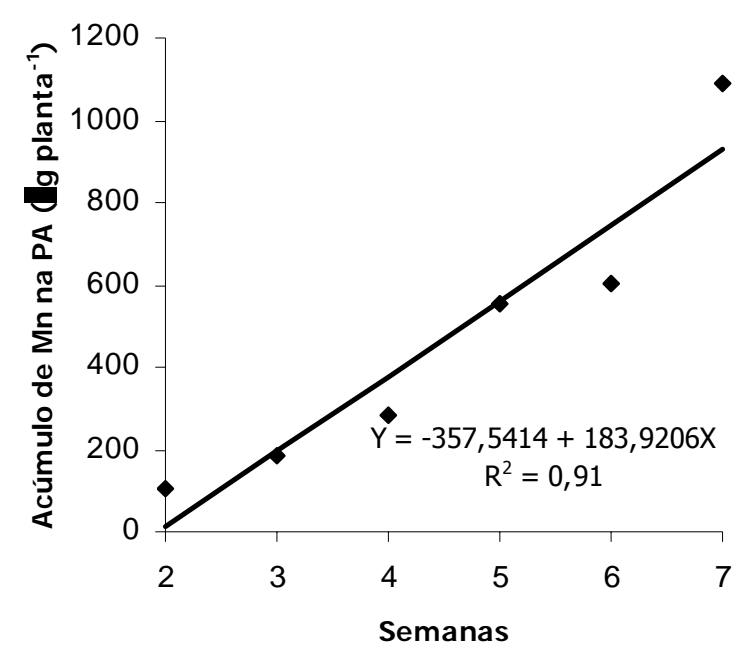

Figura 27 - Manganês acumulado na parte aérea para os tratamentos ( $\mu \mathrm{g} \mathrm{planta}^{-1}$ )

O maior acúmulo de manganês na parte aérea das plantas ocorreu na semana 7 aos 53 DAT e foi de 929,90 $\mu \mathrm{g}$ planta ${ }^{-1}$. No entanto, não foi observado o acúmulo máximo de manganês na parte aérea das plantas para esses tratamentos.

A taxa de exportação de manganês obtida pelos valores médios na semana 7, por ocasião da colheita, aos 53 DAT foi $92 \%\left(1.086,27 \mu\right.$ planta $\left.^{-1}\right)$ na parte aérea, seguida de $6 \%\left(68,32 \mu \mathrm{g}\right.$ planta $\left.^{-1}\right)$ nas raízes e $2 \%\left(17,60 \mu \mathrm{g}\right.$ planta $\left.{ }^{-1}\right)$ nos minitubérculos.

$\mathrm{O}$ acúmulo de manganês nas raízes foi significativo $(\mathrm{P}<0,05)$, e ajustou-se ao modelo quadrático de regressão. O maior acúmulo ocorreu na semana 7 aos 53 DAT, no entanto o valor obtido pelo R-Quadrado foi mediano $\left(R^{2}=0,63\right)$. Portanto os valores obtidos nos tratamentos não são demonstrados por figura.

$\mathrm{O}$ acúmulo máximo de manganês nos minitubérculos foi significativo $(P<0,05)$ e ajustou-se ao modelo linear de regressão (Figura 28). Observou-se que o acúmulo de manganês nos minitubérculos apresentou um aumento constante, para $X \in[2 ; 7]$. 0 acúmulo de manganês aumentou a cada semana (X) 4,27 mg (Y). 


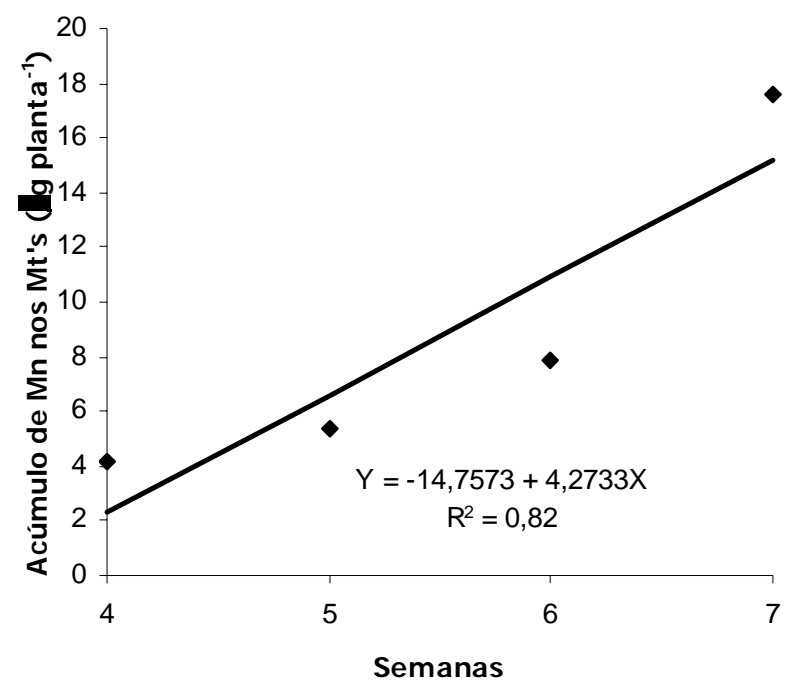

Figura 28 - Manganês acumulado nos minitubérculos para os tratamentos ( $\mu \mathrm{g} \mathrm{planta}^{-1}$ )

O maior acúmulo de manganês nos minitubérculos ocorreu na semana 7 aos 53 DAT e foi de $15,16 \mu$ planta $^{-1}$. No entanto, o acúmulo máximo de manganês nos minitubérculos não foi observado para esses tratamentos.

Paula et al. (1986) observaram que os maiores teores de manganês ocorreram nas folhas seguidas do caule, raízes. Bolle-Jones (1955) relatou que a aplicação de potássio e fósforo reduz a proporção de manganês nas raízes, o que não coincide com os dados deste trabalho, onde as plantas apresentaram $17 \%$ do teor total de manganês, conferindo proporção maior na parte aérea e menor nos minitubérculos (5\%).

As folhas absorvem maiores quantidades de manganês e as raízes menores. $\mathrm{Na}$ colheita aos 53 DAT, os valores médios obtidos pela parte aérea apresentaram $92 \%$ do manganês total e apenas $6 \%$ nas raízes. Observou-se um aumento contínuo no acúmulo de manganês pela parte aérea das plantas e pelos minitubérculos nos tratamentos, enquanto que, nas raízes o maior acúmulo de manganês ocorreu na semana 6 , aos 46 DAT e foi de $7 \%\left(86,80 \mu\right.$ planta $\left.^{-1}\right)$.

Comportamento diferente foi verificado por Paula et al. (1986), no cv. Mantiqueira, nas primeiras amostragens, a maior parte do manganês acumulou-se nas 
folhas e nas últimas nos tubérculos. Assim, aos 20 DAP, $85 \%$ do total acumulado estava nas folhas; aos $40 \mathrm{DAP}, 65 \%$ nas folhas e $9 \%$ nos tuberculose aos $100 \mathrm{DAP}$, $47 \%$ nas folhas e $27 \%$ nos tubérculos.

A taxa de maior acúmulo de manganês, pelo cv. Atlantic, nas raízes ocorreu no crescimento vegetativo, da emergência até 20 DAP, nas folhas e tubérculos ocorreu no enchimento de tubérculos, de 42 a 28 e de 49 a 55 DAP, nos caules, na maturação, de 84 a 90 DAP. A exportação de manganês correspondeu a $11 \%$ do acúmulo máximo total. Nas raízes e folhas o acúmulo máximo de manganês ocorreu no estádio de enchimento de tubérculos, nos caules e tubérculos ocorreu na maturação (Yorinori, 2003).

\subsubsection{Zinco}

$\mathrm{O}$ acúmulo de zinco na parte aérea foi significativo $(\mathrm{P}<0,01)$ e ajustou-se ao modelo quadrático de regressão (Figura 29).

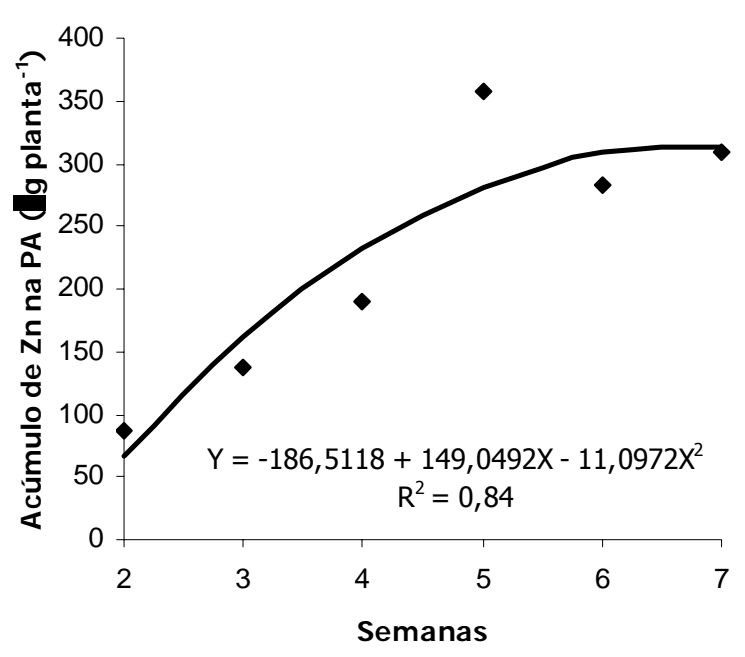

Figura 29 - Zinco acumulado na parte aérea para os tratamentos ( $\mu \mathrm{g}_{\text {planta }}{ }^{-1}$ )

O maior acúmulo de zinco na parte aérea das plantas ocorreu entre semana 6 e 7 aos 47 DAT e foi de 239,44 $\mu$ planta $^{-1}$.

A taxa de exportação de zinco obtida pelos valores médios pela colheita na 
semana 7 aos 53 DAT foi $66 \%\left(309,51 \mu \mathrm{g}_{\text {planta }}^{-1}\right)$ na parte aérea, seguida de $21 \%$ $\left(98,10 \mu\right.$ p planta $\left.^{-1}\right)$ nas raízes e $13 \%\left(62,67 \mu \mathrm{g}\right.$ planta $\left.^{-1}\right)$ nos minitubérculos. O acúmulo máximo de manganês total obtido na colheita aos 53 DAT apresentou valor médio de $470,28 \mu$ planta $^{-1}$.

No estádio de crescimento vegetativo, dos 18 aos 32 DAT, o acúmulo de zinco na parte aérea das plantas foi contínuo, no entanto observou-se maior acúmulo aos 39 DAT na semana 5. Na fase de maturação, aos 53 DAT, período da colheita, o acúmulo foi menor, possivelmente pelas plantas entrarem em estádio de senescência.

$\mathrm{O}$ acúmulo de zinco nas raízes foi significativo $(\mathrm{P}<0,01)$ e ajustou-se ao modelo de regressão linear (Figura 30). O maior acúmulo de zinco ocorreu na semana 5 aos 39 DAT e foi de $69,70 \mu$ planta $^{-1}$.

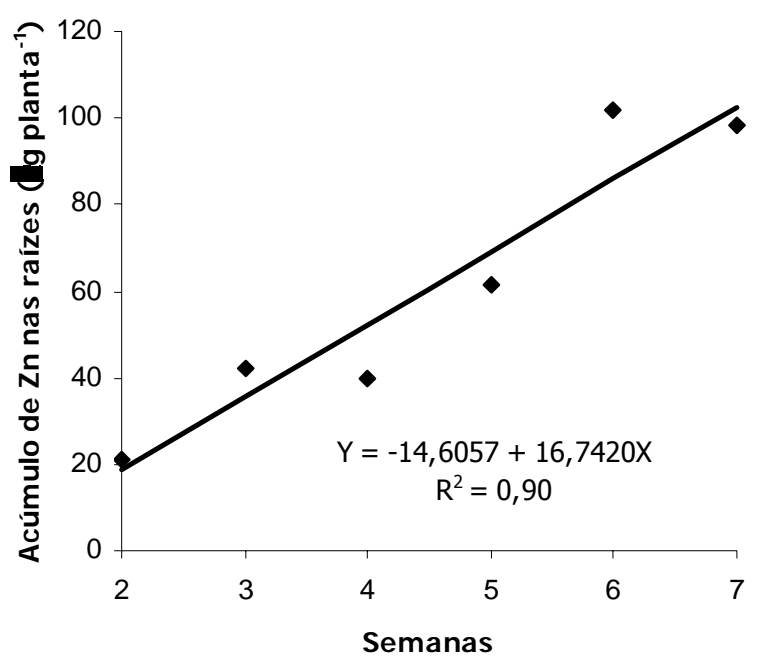

Figura 30 - Zinco acumulado nas raízes para os tratamentos ( $\mu \mathrm{g}$ planta $^{-1}$ )

O maior acúmulo de zinco nas raízes ocorreu na semana 7 aos 53 DAT e foi de $102,59 \mu \mathrm{g}$ planta $^{-1}$. No entanto, o acúmulo máximo de zinco nas raízes não foi observado para esses tratamentos.

No presente trabalho os valores médios demonstram que os menores teores de zinco nas raízes foram encontrados no estádio de tuberização e os maiores na 
maturação, aos 46 e 53 DAT. Na parte aérea, os maiores teores de zinco ocorreram na maturação, o mesmo ocorreu nos minitubérculos das plantas.

Entretanto, resultados obtidos por Yorinori (2003) pelo cv. Atlantic, conferiu o maior acúmulo de zinco nas raízes e caules no estádio de tuberização (35 a 41 e 42 a 48 DAP, respectivamente), enquanto que, nas folhas e tubérculos, ocorreu na maturação (77 a 83 e 63 a 69 DAP, respectivamente).

$\mathrm{O}$ acúmulo de zinco nos minitubérculos foi significativo $(P<0,05)$ e ajustou-se ao modelo quadrático de regressão (Figura 31).

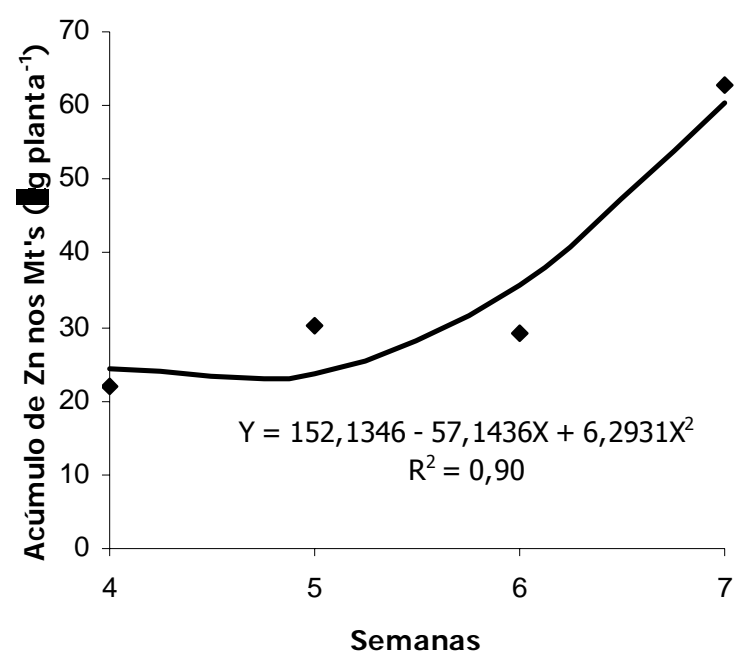

Figura 31 - Zinco acumulado nos minitubérculos para os tratamentos ( $\mu$ planta $^{-1}$ )

O maior acúmulo de zinco ocorreu entre a semana 4 e 5 a partir dos 32 DAT e foi de $22,41 \mu$ planta $^{-1}$. Foi observado comportamento diferente para este nutriente, 0 qual não apresentou o maior acúmulo no período da colheita aos 53 DAT, como a maioria dos nutrientes avaliados.

De acordo com Paula et al. (1986), aos 60 DAP, 20\% do zinco total encontravase nas folhas e $53 \%$ nos tubérculos no cv. Mantiqueira. Observaram, ainda, que nas primeiras amostragens a maior porcentagem da quantidade acumulada de zinco encontrava-se nas folhas e as menores nos tubérculos. Ao longo da amostragem houve 
inversão na distribuição percentual da quantidade acumulada de zinco nas folhas e nos tubérculos.

O maior acúmulo de zinco nos minitubérculos ocorreu aos 53 DAT no período da colheita das plantas e os valores médios obtidos foram de $13 \%\left(62,67 \mu \mathrm{g}\right.$ planta $\left.{ }^{-1}\right)$. Quantidades maiores foram encontradas por Paula et al. (1986) nos cvs. Achat e Mantiquerira e também por Yorinori (2003) com o cv. Atlantic.

O maior acúmulo dos micronutrientes na parte aérea das plantas ocorreu no período da colheita, na semana 7 aos 53 DAT. Nas raízes, o maior acúmulo dos micronutrientes ocorreu na semana 6 aos 46 DAT, sendo que para o boro valores médios indicam que o maior acúmulo ocorreu na semana 3 aos 25 DAT e para o cobre os valores médios indicam que o maior acúmulo ocorreu na semana 2 aos 18 DAT. Nos minitubérculos o maior acúmulo ocorreu na semana 7 aos 53 DAT.

Contudo, deve-se considerar que para as variáveis avaliadas nesse estudo, os parâmetros relacionados ao crescimento das plantas, como: altura, diâmetro dos tubérculos, peso fresco dos minitubérculos, peso seco dos minituberculos, peso seco da parte aérea e peso seco total das plantas ajustaram-se melhor ao modelo de regressão linear, esse comportamento sugere um período maior do ciclo para atingir resultados superiores comparando com esses obtidos. Enquanto que, para os nutrientes: $\mathrm{K}, \mathrm{Ca}$, $\mathrm{Mg}, \mathrm{B}, \mathrm{Fe}, \mathrm{Mn}$, na parte aérea, assim como $\mathrm{B}$ e $\mathrm{Mn}$ nos minitubérculos e $\mathrm{Zn}$ nas raízes ajustaram-se também ao modelo de regressão linear, portanto, a mesma sugestão é válida.

O número de hastes, o número de folhas e o número de tubérculos ajustaramse ao modelo quadrático de regressão, assim como os nutrientes: $N, P, S, Z n$, na parte aérea; $\mathrm{P}$ e Ca nas raízes e N, P, Cu e Zn nos minitubérculos. Para essas variáveis avaliadas os valores obtidos indicam que o período do estudo foi suficiente para atingir valores adequados para a produção de minitubérculos e observou-se uma estabilização para os determinados nutrientes.

Segundo Magalhães (1985), as médias de vários experimentos realizados com a cultura da batata, indicam a seguinte percentagem dos nutrientes exportados pelos tubérculos em relação à planta toda: $80 \%$ de fósforo; $61 \%$ de potássio; $60 \%$ de nitrogênio; $53 \%$ de enxofre; $25 \%$ de magnésio; $23 \%$ de ferro; $19 \%$ de cobre; $10 \%$ de 
cálcio e $9 \%$ de boro.

Com relação ao acúmulo de nutrientes na parte aérea da batata, resultados obtidos por Feltran (2001), forneceram a seguinte seqüência: $\mathrm{K}>\mathrm{Ca}>\mathrm{N}>\mathrm{Mg}>\mathrm{P}>$ Zn > B. Enquanto que, a seqüência de acúmulo máximo pelo cv. Atlantic determinado por Yorinori (2003) foi: nitrogênio > potássio > cálcio > fósforo > magnésio > enxofre $>$ ferro $>$ manganês $>$ zinco $>$ boro $>$ cobre.

O acúmulo máximo total dos nutrientes pelo cv. Atlantic foi: potássio $(682,59)$; nitrogênio $(320,33)$; cálcio $(201,72)$; fósforo $(70,00)$; magnésio $(65,87)$ e enxofre $(26,46)$ em g planta ${ }^{-1}$. Sendo que, para: ferro $(1.894,42)$; manganês $(1.172,19)$ boro $(848,58)$; zinco $(470,28)$ e cobre $(100,72)$ em mg planta ${ }^{-1}$.

Com relação à marcha de absorção de nutrientes determinada nesse estudo pelas plantas deve-se considerar o material de origem utilizado. Plantas provenientes de cultura de tecidos são bem menos vigorosas comparadas às plantas obtidas a partir de tubérculos de batata-semente, os quais possuem suas próprias reservas.

Outros fatores importantes que definem os resultados de produção são: a duração do ciclo da cultura, o sistema de cultivo, o fornecimento dos nutrientes, o cultivar, entre outros, destes, a duração do ciclo é o que mais influencia.

Resultados obtidos nesse estudo indicam que os valores obtidos referentes aos parâmetros de crescimento e a absorção de nutrientes são inferiores comparados aos resultados obtidos na literatura. Entretanto, deve-se considerar que, a maioria dos resultados foi obtida em condições de campo, apresentando um ciclo maior e utilizando tubérculos de batata na propagação vegetativa.

\subsection{Considerações finais}

Os resultados encontrados na literatura referentes aos parâmetros de crescimento e à marcha de absorção de nutrientes em cultivo de batata visando a produção de minitubérculos são praticamente inexistentes nos sistemas de produção em uso, inclusive no hidropônico. Ao mesmo tempo, consiste na oportunidade de pesquisa, visto a importância crescente e econômica da produção de minitubérculos em ambiente protegido utilizando diferentes sistemas de produção.

Embora grandes progressos venham sendo feitos no estudo desses elementos, 
muitos dos problemas referentes a esse assunto, com especial referência do papel específico de cada um deles sobre a planta, ainda continuam pouco esclarecidos.

A introdução de novos métodos de produção de sementes pré-básicas que propiciem maiores taxas de multiplicação, seguramente representa um avanço na cadeia produtiva da batata, capaz de produzir reflexos positivos na produtividade, particularmente em regiões onde a qualidade das sementes utilizadas é fator limitante para a obtenção de maiores rendimentos.

Aspectos como condições de cultivo e estado nutricional das plantas, assim como, processos dos transplantes, são importantes e deveriam receber maior atenção. O comportamento das mudas pode variar de um cultivar para outro mesmo sob condições idênticas, sendo este outro aspecto importante a ser pesquisado.

O estudo das curvas de absorção de nutrientes pela planta contribui para o conhecimento das necessidades nutricionais nos vários estádios do ciclo vegetativo, indicando as quantidades de nutrientes absorvidas para uma certa produção de matéria seca. Diversas curvas são estabelecidas para cada elemento, de acordo com o órgão da planta e a idade. Se há suspeita de deficiência ou de toxidez de nutriente, medidas são tomadas para corrigir o sintoma, antes de prejudicar o crescimento e a produtividade.

Uma planta nutrida adequadamente possui uma maior resistência à deficiência hídrica e ao ataque de pragas e doenças. As produtividades alcançadas são maiores e a qualidade do produto final é superior. O resultado é uma otimização no retorno econômico em função do capital investido pelo agricultor. 


\section{CONCLUSÕES}

$\checkmark$ Os parâmetros de crescimento avaliados na produção de MT's apresentaram crescimento rápido e dinâmico no sistema hidropônico em ambiente protegido.

Observou-se uma relação positiva entre à altura das plantas e o número de folhas planta ${ }^{-1}$, assim como o número de hastes emitidas e o número de minitubérculos produzidos por planta.

$\checkmark$ O diâmetro dos minitubérculos e o peso do material fresco dos minitubérculos apresentaram relação positiva.

$\checkmark \quad$ O peso do material seco da parte aérea das plantas e o peso do material seco dos minitubérculos apresentaram relação positiva.

$\checkmark$ O acúmulo de peso do material seco total das plantas e os demais parâmetros de crescimento avaliados também apresentaram uma relação positiva para os tratamentos.

$\checkmark$ A seqüência do acúmulo máximo dos macronutrientes para os tratamentos foi: $\mathrm{K}>\mathrm{N}>\mathrm{Ca}>\mathrm{P}>\mathrm{Mg}>\mathrm{S}$. Enquanto que, a seqüência do acúmulo máximo dos micronutrientes para os tratamentos foi: $\mathrm{Fe}>\mathrm{Mn}>\mathrm{B}>\mathrm{Zn}>\mathrm{Cu}$.

$\checkmark$ A seqüência de exportação dos macronutrientes foi: potássio > nitrogênio > fósforo $>$ enxofre $>$ magnésio $>$ cálcio. Enquanto que, a taxa de exportação dos micronutrientes foi: ferro $>$ zinco $>$ cobre $>$ boro $>$ manganês.

$\checkmark$ O sistema hidropônico permitiu disponibilizar os nutrientes de forma mais prontamente assimiláveis pelas plantas.

$\checkmark$ Os resultados obtidos nesse estudo, tanto para os parâmetros de crescimento, quanto para a marcha de absorção de nutrientes servem de orientação para o fornecimento dos nutrientes em quantidades adequadas para a produção de minitubérculos de batata-semente. 


\section{REFERÊNCI AS BI BLI OGRÁFICAS}

ABAK, K.; CELIKEL, G. Comparison of some Turkish originated organic and inorganic substrates for tomato soiless culture. Acta Horticulturae, n. 366, p. 423-429, 1994.

ABBA. Valor nutricional. A batata como alimento. http://abbabatatabrasileira.com.br (29 nov. 2004).

ABREU, M.F. de; ABREU, C.A. de; BATAGLIA, O.C. Uso da análise química na avaliação da qualidade de substratos e componentes. In: ENCONTRO NACIONAL DE SUBSTRATOS PARA PLANTAS, 3., Campinas, 2002. Campinas: IAC, 2002.p.17-28 (IAC. Documentos, 70).

ADAMS, P. Nutrition of greenhouse vegetable in NFT and hydroponic systems. Acta Horticulturae, n. 361, p.254-257, 1994.

AMON, D.L.; STOUT, P.R. The essentialy of certain elements in minute quantity for plants with special reference to cooper. Plant Physiology. v. 14, p. 371-375, 1939.

ANDREU, M.A. Industrialização e melhoramento genético da batata: Desafios para um futuro próximo. Batata Show, n.8, p. 22, 2003. 
ANDRIOLO, J.L.; DUARTE, T.S.; LUDKEL, L.; SHREBSKY, E.C. Crescimento e desenvolvimento do tomateiro cultivado em substrato com fertirrigação. Horticultura Brasileira, v. 15, n.1, p. 28-32, 1997.

ANDRIOLO, J.L. Fisiologia das culturas protegidas. Santa Maria: UFSM, 1999. $142 p$.

ANTUNES, F.Z.; FORTES, M. Exigências climáticas da cultura da batata. Informe Agropecuário, v. 7, n. 76, p. 19-23, 1981.

ARAÚJO, W.P. Manejo da fertirrigação em mudas de alface produzidas em substrato. Campinas, 2003. 70p. Dissertação (Mestrado) - Instituto Agronômico.

BAILLE, M.; BAILLE, A.; DELMON, D. Microclimate and transpiration of greenhouse rose crops. Agricultural and Forest Meteorology, v. 71, p. 83-97, 1994.

BENINCASA, M.M.P. Fisiologia vegetal, Jaboticabal: Funep, 2002. 168p.

BERBARI, S.A.G.; AGUIRRE, J.M de. Alternativas para o aproveitamento industrial de batata. Batata Show, v. 2, n.4, p.27, 2002.

BOLLE-JONES, E.W. The effect of varied nutrient levels on the concentration and distribution of manganeses within the potato plant. Plant and soil, v. 6, n.1, p. 45-60, 1955.

BREGAGNOLI, M.; MINAMI, K.; BREGAGNOLI, F.C.R.; SANTOS, M.A.; CARVALHO, C.A.M. Acúmulo de nutrientes pela cultura da batata cv. Atlantic sob 4 níveis de adubação. (Compact disc.) Horticultura Brasileira, v. 22, n.2, Supl. jul. 2004.

BURTON, W.G. Challenges for stress physiology in potato. American Potato J ournal, v.58, n.1, p.3-14, 1981. 
CALBO, A.G.; SILVA, W.L.C.; TORRES, A.T. Composição de modelos e estratégias para análise de crescimento. Revista Brasileira de Fisiologia Vegetal, v.1, n.1, p.17, 1989.

CALDEVILLA, E.M.:LOZANO, M.G. Cultivos sin suelo: hortalizas en clima mediterraneo. Reus: Ediciones de horticultura, 1993. 123 p.

CAMARGO FILHO, W.P. Produto Interno Bruto (PIB) da cadeia produtiva da batata. Batata Show, v. 1, n. 2, p. 22, 2001.

CAPEZIO, S.; HUARTE, M.; CARROZZI, L. Seleccion por peso especifico em generaciones tempranas em el mejoramiento de la papa. Revista Latinoamericana de la papa,v. 5/6, p. 54-63, 1993.

CASTRO, J.L. Forçamento da brotação em batata-semente. Tecnologia e produção de batata-semente. Brasília: AGIPLAN, 1976. p. 35-45.

CHANG, D.C.; KIM, S.Y.; HAHM, Y.; SHIN, K.Y. Hidroponic culture system for the production of seed tubers without soil. American J ournal of Potato Research, v.77, n. 6, p. 394, 2000.

CORRÊA, R.M.; PINTO, J.E.B.P.; REIS, E.S.; PINTO, L.B.B, BOTREL, P.P.; ROSADO, L.S.; BERTOLUCCI, S.K.V. Número de plantas por vaso na produção de batatasemente. (Compact disc.) Horticultura Brasileira, v. 22, n.2, Supl. jul. 2004.

COSTA, D.M.da. Batata-semente, como obtê-la melhor. Pelotas: IPEAS, 1969. (Circular Técnico,39). 
CUNHA, B. P. da.; MEDEIROS, C.A.B. Diferenciação de tubérculos de batata em função da concentração de nitrogênio na solução nutritiva. (Compact disc.) Horticultura Brasileira, v. 22, n.2, Suplem. jul. 2004.

DANIELS, J. Sementeiro: opção para melhorar a sanidade da batata-semente no Rio Grande do Sul. Pelotas: Embrapa, UAEPE de Cascata, 1983. 5 p. (Comunicado Técnico, 26).

DANIELS, J. Produção de batata-semente. Seed News, v.5, n. 4, p. 14-15, 2001.

DANIELS, J. Batata-semente pré-básica: multiplicação por hidroponia. In: PEREIRA, A.S. da; DANIELS, J. (Eds.). O cultivo da batata na região sul do Brasil. p. 444-474, 2003.

DANIELS, J.; PEREIRA, A.S.; FORETS, G.R.L. Verticalização da produção da batata-semente por produtores de agricultura familiar no Rio Grande do Sul. Pelotas: Embrapa Clima Temperado, 2000a. 4p. (Comunicado Técnico).

DANIELS, J.; SILVA, A.C.F.: SOUZA, Z.S. Degenerescência da batata-semente nas principais regiões produtoras dos estados de Santa Catarina e do Rio Grande do Sul. In: REUNIÃO TÉCNICA ANUAL DE PESQUISA E EXTENSÃO DA CULTURA DA BATATA DA REGIÃO SUL DO BRASIL. 7. Curitiba, 2000. Resumos. Curitiba: IAPAR, 2000b. p. 39.

DIAS, J.A.C.de. Doenças causadas por vírus em batata. Informe Agropecuário, v.18, n.184, p. 2, 1996.

ELMA CHIPS. Manual de recomendações técnicas para produção da variedade Atlantic. 5. ed. Itu, 2000. 22p. 
EMPRESA BRASILEIRA DE PESQUISA AGROPECUÁRIA. A cultura da batata. Brasília: EMBRAPA SNH, 1999. 184p.

EMPRESA BRASILEIRA DE PESQUISA AGROPECUÁRIA. Manual de procedimentos da Embrapa negócios tecnológicos para produção e comercialização de batata-semente básica marca Embrapa. Canoinhas: Embrapa SNT, 2000. 43p.

EPSTEIN, E. Nutrição mineral das plantas: princípios e perspectivas. São Paulo: Editora da Universidade de São Paulo, 1975. 341p.

ERREBI, M.; ROSEN, C.J.; GUPTA, S.C.; BIRONG, D.E. Potato yield response and nitrate leaching as influenced by nitrogen management. Agronomy J ournal, v. 90, p. 10-15, 1998.

EWING, E.E. Potato. In: WIEN, H.C. The physiology of vegetable crops. CABI, 1997. p. 295-344.

EZETA, F.N.;McCOLLUM, R.E. Dry-matter production and nutrient uptake and removal by Solanum andigena in the Peruvian Andes. American Potato Research, v. 49, p. $151-163,1972$.

FABRI, E.G.; SALA, F.C.; MINAMI, K. Caracterização física e química de diferentes substratos. In: BARBOSA, J.G.; MARTINEZ, H.E.P.; PEDROSA, M.W.; SEDIYAMA, M.A.N. (Ed.). Nutrição e adubação de plantas cultivadas em substrato. Viçosa: UFV, 2004. p. 318.

FAYAD, J.A. Absorção de nutrientes, crescimento e produção do tomateiro cultivado em condições de campo e estufa. Viçosa, 1998. 81 p. Tese (Mestrado) Universidade Federal de Viçosa. 
FAYAD, J.A.; MONDARDO, M.; OLIVEIRA, S.O.de. Absorção de nutrientes, crescimento e produção de tomate, cultivado no sistema de plantio direto. Boletim técnico. Epagri, n. 2, p. 14, 2000.

FELTRAN, J.C.; LEMOS, L.B. Acúmulo de nutrientes na parte aérea e nos tubérculos em cultivares de batata (Solanum tuberosum L.) In: ENCONTRO NACIONAL DE PRODUÇÃO E ABASTECIMENTO DE BATATA, 11., SEMINÁRIO NACIONAL DE BATATA-SEMENTE, 7.; Uberlândia, 2001. Resumos. Uberlândia: ABBA, 2001.

p. 21-25.

FERNANDES, C.; CORÁ, J.E.; ARAÚJO, J.A.C.de. In: WORKSHOP DE FERTIRRIGAÇÃO, 2. Teores foliares de nutrientes em tomateiro cultivado em substrato com parcelamento da fertirrigação. Piracicaba, 2001. p. 201-210.

FILGUEIRA, F.A.R. Práticas agronômicas. In: REIFSHENEIDER, F.J.B. (Coord.) Produção de batata. Brasília: Linha gráfica, 1987, p. 29-39.

FILGUEIRA, F.A.R. Novo manual de olericultura: agrotecnologia moderna na produção e comercialização de hortaliças. Viçosa: UFV, 2000. 402p.

FILGUEIRA, F.A.R. Novo manual de olericultura: agrotecnologia moderna na produção e comercialização de hortaliças. Viçosa: UFV, 2003. 412p.

FIOREZE, C. Diagnóstico das regiões produtoras de batata do Rio Grande do Sul. In: GUEDES, J.V.C. (Ed.). SEMINÁRIO DE ATUALIZAÇÃO NA CULTURA DA BATATA. Santa Maria: UFSM, EMATER, 1997. p.13-25.

FNP CONSULTORIA \& AGROINFORMATIVOS - AGRIANUAL 2004. Anuário da agricultura brasileira. São Paulo, 2004. p.172-174. 
FONTES, P.C.R. Nutrição mineral e adubação. In: REIFSHENEIDER, F.J.B. (Coord.) Produção de batata. Brasília: Linha gráfica, 1987, 239p.

FONTES, P.C.R.; FINGER, F.L. Dormência dos tubérculos, crescimento da parte aérea e tuberização da batateira. I nforme Agropecuário, v.20, n.197, p.24-29, 1999.

FORTES, G. R.L.; ROOS, F.C.; FLORES, R.; DANTAS, A.C.M. Multiplicação in vitro de batata (Solanum tuberosum L.) em meios semi-sólidos e líquido com diferentes concentrações de sacarose. Pelotas: Embrapa Clima Temperado, 1998. 5 p. (Pesquisa em Andamento).

FORTES, G. R. de; PEREIRA, J. E. S. In: PEREIRA, A.S.da; DANIELS, J. (Ed.). O cultivo da batata na Região Sul do Brasil. Brasília: Embrapa, 2003. p. 69.

FURLANI, P.R.; BOLONHESI, L.C.P.; FANQUIN, V. Cultivo hidropônico de Plantas. Campinas: Instituto Agronômico, 1999. 52p. (Boletim técnico, 180).

FURUMOTO, O. Épocas de plantio. In: LOPES, C.A.; BUSO, J.A. Cultivo da batata (Solanum tuberosum L.) Brasília: EMBRAPA, 1997. 35 p. (Instruções Técnicas da Embrapa Hortaliças, 8).

FURUMOTO, O.; LOPES, C.A. Batata-semente. In: LOPES, C.A.; BUSO, J.A. Cultivo da batata (Solanum tuberosum L.) Brasília: EMBRAPA, 1997. 35 p. (Instruções Técnicas da Embrapa Hortaliças, 8).

GALLO, J.R.; COELHO, F.A.S.; NÓBREGA, S.de. A. Análise de folíolos e pecíolos na diagnose da nutrição da batatinha. Bragantia, v. 24, n.30, p. 385-401, 1965.

GRANJA, N.P. do.; MIRANDA FILHO, H.S. da; MAIA, N.B.; BOVI, O.A. Formação do estoque nuclear de batata-semente em cultivo hidropônico com substrato. Compact disc. Horticultura Brasileira, v. 21, n.2, Supl. jul, 2003. 
GREGORY, F.G. The effect of climatic conditions on the growth of barley. Annals of Botany, v.40, p.1-26, 1926.

HAAG, P.H.; OLIVEIRA, G.D. de; BARBOSA, V.; SILVA NETO, J.M. de. Marcha de absorção de nutrientes pelo tomateiro (Lycopersicum esculentum Mill) destinado ao processamento industrial. In: HAAG, H.P.; MINAMI, K. Nutrição mineral de hortaliças. Campinas: Fundação Cargil, 1981. p. 447-474.

HAEDER, H.E.; BERINGER, H. Potencial productivity of field crops under different environments. Philippines: IRRI, 1983. p. 307-317.

HANGER, B.C. The movement of calcium in plants. Communications in Soil Science and Plant Analysis, v. 10, n. 1/2, p. 171-193, 1979.

HAYASHI, P.C.R. Produção de mini-tubérculos em cultivo hidropônico com substrato. Batata Show. n. 9, p. 30, 2004.

HAWKES, J.G. Origins of cultivated potatoes and species relationships. In: BRADSHAW, J.E.; MACKAY, G.R. (Ed.). Potato genetics. Cambridge: CAB Internacional, 1993. p.3 -42 .

HAWKES, J.G.; FRANCISCO-ORTEGA, J. The potato in Spain during the late 16th century. Economic Botany, v. 86, p. 89-97, 1992.

HAWKINS, A. Rate of absortion and translocation of mineral nutrients by potatoes in Aroostook Country, Maine and their relation to fertilizer practices. J ournal of the America Society of Agronomy, v. 38, n.8, p. 667-681, 1946.

HIRANO, E. Produção de semente. In: REIFSHENEIDER, F.J.B. (Coord.) Produção de batata. Brasília: Linha gráfica, 1987. p. 171-183. 
HIRANO, E. Produção de batata-semente pela EMBRAPA. Batata Show, v.2, n.4, p.23, 2002.

HIROCE, R.; GALO, J.R.; NÓBREGA, S.A. de. Deficiência de boro em batatinha cultivada em solo orgânico do Vale do Paraíba. Bragantia, v.30, n.2, p.5-7, 1971.

HOAGLAND, D.R.; ARNON, D.L. The water culture methods for growing plants without soil. Berkeley: University of California, 1950. 32p. (Circular, 347).

HUGLES, J.C. Factors influencing the quality of ware potatoes. 2. Enviromental factors. Potato Research, v.17, p. 512-547, 1974.

HUYLENBROECK, van.; J.M.; DEBERGH, P.C. Physiological aspects in acclimatization of micropropagated plantlets. Plant Tissue Culture and Biotechnology, v. 2, n. 3, p.136-141, 1996.

JOERN, B.C.; VITOSH, M.L. Influence of applied nitrogen on potato. Part I: Yield, quality and nitrogen uptake. American Potato J ournal, v. 72, p. 53-63, 1995.

JONES JUNIOR, J.B. A guide for the hydroponic and soiless culture grower. Portland: Timber Press, 1983. 124p.

KAWAKAMI, J. Crescimento e produtividade a campo de batatas originadas de microtubérculos. (Compact disc.) Horticultura Brasileira, v. 22, n.2, jul. Supl. 2004.

KERBAUY, G.B. Clonagem de plantas in vitro Biotecnologia, Ciência e Desenvolvimento, v. 1, n.1, p. 30-33, 1997. 
Le HINGRAT, Y.; MARHIC, J.V. Development of hydroponical culture for large-scale production of healthy tubers. In: TRIENNIAL CONFERENCE OF THE EUROPEAN ASSOCIATION FOR POTATO RESEARCH, 14., Sorrento, 1999. Abstracts. Sorrento: Assessorato Agricoltura Regione Campania, 1999. p. 54-55.

LEMAIRE, F. Physical, chemical and biological properties as growing medium. Acta Horticulturae, n. 396, p. 273-284, 1995.

LEWIS, R.J. Petiole nitrate profiles and $\mathrm{N}$ uptake: comparison among seven potato cultivars. Aberdeen: 1989. 24p. (Tese Ph.D.). Brigham Young University.

LIEFRINK, S.R. Batata-semente Neerlandês bem inspecionada: A importância de material de propagação aprovado, Den Haag: NIVAA, s.d. 36p.

LOPES, C.A.; FURUMOTO, O. In: LOPES, C.A.; BUSO, J.A. Cultivo da batata (Solanum tuberosum L.) Brasília: EMBRAPA, 1997. 35 p. (Instruções Técnicas da Embrapa Hortaliças, 8).

LUCCHESI, A.A. Fatores da produção vegetal. In: CASTRO, P.C.R.; FERRERIA, S.O.; YAMADA, T. (Ed). Ecofisiologia da produção agrícola. Potafós, Piracicaba: SP, 1987. p. $1-2$.

MAGALHÃES, J.R. Nutrição e adubação da batata. São Paulo: Nobel, 1985, 51p.

MALAVOLTA, E. Elementos de nutrição mineral de plantas. Piracicaba: Agronômica Ceres, 1980. 251p.

MALAVOLTA, E.; VITTI, G.C.; OLIVEIRA, S.A. de. Avaliação do estado nutricional das plantas: princípios e aplicações. 2. ed. Piracicaba: POTAFÓS, 1997. 319p. 
MARSCHNER, H. Mineral nutrition of higher plants. 2. ed. San Diego: Academic Press, 1995. 889p.

MARINUS, J.; BODLANEENDER, K.B.A. Response of some potato varieties to temperature. Potato Research, v. 18, p. 189-201, 1975.

MARTINEZ, P.F. Manejo de substratos para horticultura In: FURLANI, A.M.C.; BATAGLIA, O.C.; ABREU, M.F.; FURLANI, P.R.; QUAGGIO, J.A.; MINAMI, K. Caracterização, manejo e qualidade de substratos para produção de plantas. Campinas: IAC, 2002. p. 53-76. (IAC Documentos, 70).

MARTINEZ, H.E.P.; SILVA FILHO, J.B. Introdução ao cultivo hidropônico de plantas. Viçosa: UFV, 1997. 52p.

McDOLE, R.E.; STALLKNECHT, G.F.; DWELLE, R.B.; PAVEK, J.J. Response of four potato varieties to potassium fertilization in a seed growing area of Idaho. American Potato J ournal, v. 55 n. 9, p. 495-504, 1978.

MEDEIROS, C.A.B. Batata-semente pré-básica: multiplicação por hidroponia. In: PEREIRA, A.S. da; DANIELS, J. (Ed.). O cultivo da batata na região sul do Brasil. Brasília: CIT, 2003. p. 444-474.

MEDEIROS, C.A.B.; SILVA, E.S.B. Produção de sementes pré-básicas de batata em sistema de cultivo sem solo. Horticultura Brasileira, v. 17, n.3, p. 300, 1999.

MEDEIROS, C.A.B.; ZIEMER, A.H.; PEREIRA, A.S.; DANIELS, J. Estrutura de sistema hidropônico para produção de sementes pré-básicas de batata. Brasília: Embrapa, 2000. 10p. (Comunicado técnico, 29). 
MEDEIROS, C.A.B.; ZIEMER, A.H.; DANIELS, J.; PEREIRA, A.S. da. Produção de sementes pré-básicas de batata em sistemas hidropônicos. Horticultura Brasileira, v. 20, p. 110-114, 2002.

MELO, P.C.T. de; GRANJA, N.P. do; MIRANDA FILHO, H. S. da; SUGAWARA, A.C.; OLIVEIRA, R.F.de. Análise do crescimento da cultivar de batata "Ágata". Batata Show, v.3, n.8, p. 6-17, 2003.

MELO, P.E. Cultivares de batata potencialmente úteis para processamento na forma de fritura no Brasil e manejo para obtenção de tubérculos adequados. Informe Agropecuário, v. 20, n. 197, p. 112-119, 1999.

MEYER, RD.; MARCUM, D.B. Potato yield, petiole nitrogen and soil nitrogen response to water and nitrogen. Agronomy J ournal, v. 90, p. 420-229, 1998.

MIDMORE, D.J. Fisiologia de la planta de papa bajo condiciones de clima cálido. Lima: CIP, 1987. 14p.

MILNER, L. Manejo de irrigação e fertirrigação de substratos. In: FURLANI, A.M.C.; BATAGLIA, O.C.; ABREU, M.F.; ABREU, C.A.; FURLANI, P.R.; QUAGGIO, J.A.; MINAMI, K. (Coord.). Caracterização manejo e qualidade de substratos para produção de plantas. Campinas: Instituto Agronômico, 2002. 122p. (Documentos IAC, 70).

MINER, J.A. Substratos: propriedades y caracterización. Bilbao: Mundi-Prensa, 1994. $171 p$.

MILNER, L. M Water and fertilizers management in substrates. DONADIO, L.C.; MOREIRA, C.S.; STUCHI, E.S. In: INTERNACIONAL CONGRESS OF CITRUS NURSERYMEN, 6., Ribeirão Preto, 2001. Proceedings Ribeirão Preto: sl, 2001. p. 93-95. 
MIRANDA FILHO, H. S. da. Cultura da batata In: MIRANDA FILHO, H. S. da; GRANJA, N. P. do; MELO, P.C.T.de. Vargem Grande do Sul - SP, 2003. 68p.

OJALA, J.C.; STARK, J.C.; KLEINKOPF, G.E. Influence of irrigation and nitrogen management on potato yield and quality. American Potato J ournal, v. 67, p.2943, 1990.

OLIVEIRA, A.C.S.de; MIRANDA, S.F.de. Aspectos econômicos da cultura da batata. I nforme Agropecuário, v.7, n. 76, p. 3 - 9, 1981.

PAIVA, É. A. S.e.; CASALI, V.W.D.; SILVA, E.A.M., MARTINEZ, H.E.P.; CECON, P.R.; FONTES, P.C.R.; PEREIRA, P.R.G. Qualidade de tubérculos de batata em função de doses de cálcio. Horticultura Brasileira, v.15, n.1, p. 53-57, 1997.

PAULA, M.B.; FONTES, P.C.R.; NOGUEIRA, F.D. Produção de matéria seca e absorção de macronutrientes por cultivares de batata. Horticultura Brasileira, v. 4, n.1, p. 10-16, 1986.

PEREIRA, A.S. Composição química, valor nutricional- e industrialização. In: REIFSCHNEIDER, F.J.B. (Coord.). Produção de batata, Brasília: Linha gráfica, 1987 , p. $12-16$.

PEREIRA, A.S. da; DANIELS, J. (Ed). O cultivo da batata na Região Sul do Brasil. Brasília: Embrapa, 2003. p. 419.

PINTO, P.C.A.B. Melhoramento genético da batata. Informe Agropecuário, v. 20, n. 197, p. 120-128, 1999.

POPP, P. A industrialização de batata no Brasil. In: ENCONTRO NACIONAL DE PRODUÇÃO E ABASTECIMENTO DE BATATA, 7., 1994, Araucária, Anais. Araucária, 1994, p. 60-61. 
RAIJ, B. van. Fertilidade do solo e adubação. Associação Brasileira para Pesquisa da potassa e do fosfato. São Paulo: Ceres, POTAFÓS, 1991. 343p.

REICHARDT, K. A água na produção agrícola. São Paulo, McGraw-Hill do Brasil, 1978. $119 p$.

REIS JUNIOR, R.A.; MONNERAT, P.H. Exportação de nutrientes nos tubérculos de batata em função de doses de sulfato de potássio. Horticultura Brasileira, v. 19, n.3, p. 360-364, 2001.

RESH, H.M. Hydroponic food production. 5. ed. California: Woodbridge Press, 1996. $572 p$.

ROBERTS, S.; DOLE, R.E. Potassium nutrition of potatoes. In: MUNSON, R.D. Potassium in agriculture. Madison: American Society of Agronomy, 1985. p.799-818.

RODRIGUES, L.R.F. Cultivo pela técnica de hidroponia. Técnicas de cultivo hidropônico e de controle ambiental no manejo de pragas, doenças e nutrição vegetal em ambiente protegido, Jaboticabal: Funep, 2002. 726 p.

ROMANENKO, G.A. Brasil e Rússia: a união faz a força na agricultura e na biotecnologia. Biotecnologia, n.2, p.30-33, 1997.

SAFFIGNA, P.G.; KEENEY, D.R.; KEENEY, D.R. Nitrogen and chloride uptake by irrigates Russet Burbank potatoes. Agronomy J ournal, v.69, p.258-264, 1997.

SANTOS, O.S. Conceito, histórico e vantagens da hidroponia. In: SANTOS, O. Hidroponia da alface. Santa Maria: UFSM, 2000. p. 5-9. 
SARRUGE, J. R.; HAAG, H.P. Análises químicas em plantas. Piracicaba: ESALQ, 1974. 54p.

SAS. INSTITUTE. SAS online doc: version 8. Cary, 1996.

SCHULZ, S.; WELLS, G. J.; BANIYA, B.K.; BARAKOTI, T.P.; KHAREL, G.; SAHA, B.; THAPA, B.V; OJHA, D.N. Decentralizated on-farm seed potato production from prebasic minitubers: a case study from Nepal. Experimental Agriculture, v. 34, p. 487-495, 1998.

SILVA, A.C.F. da. Batata: alguns aspectos importantes. Agropecuária Catarinense, v. 4, n. 4, p. 38-41, 1991.

SMITH, O. Potatoes: production, storing, processing. 2. ed. Westport: The Publishing, 1977. 776p.

SONNEVELD, D.C.; ENDE, J. van den; DIJK, P.A. van. Analysis of growing media by jeans of a 1:1,5 volume extract. Soil Science and Plant Analysis, v.5, n.3, p. 183-202, 1974.

SOUZA, V.F. de.; COELHO, E.F. Manejo de fertirrigação em fruteiras. In: FOLEGATTI, M.V. (Coord.). Fertirrigação: flores, frutas e hortaliças. Guaíba: Agropecuária, 2001. v.2, cap.2, p.71-103

SOUZA, Z.S.; SILVA, A.C.F. da; BEPPLER NETO, R. Cadeias produtivas do estado de Santa Catarina. Florianópolis: EPAGRI, 1999. 84p. (EPAGRI. Boletim Técnico, 104).

TAIZ, L.; ZEIGER, E. Plant physiology. Redwood City: The Benjamin-Cummings Publishing, 1991. 559p. 
TAIZ, L.; ZEIGER, E. Fisiologia Vegetal. 3. ed. Porto Alegre: Artmed, 2004. 719p.

TAVARES, S.; CASTRO, P.R.C.; MELO, P.C.T.de. Cultura da batata. Piracicaba: DIBD, 2002. 7p. (Série Produtor Rural, 18).

VALE, F. Nutrição adequada produtividade com lucro. Batata Show, n. 6. p.11. 2003.

VALOIS, A.C.C.; PAIVA, J.R. de; FERREIRA, F.R.; SOARES FILHO, W. S. dos, DANTAS, J.L.L. Melhoramento de espécies de propagação vegetativa . In: NASS, L.L.; VALOIS, A.C.C., MELO, I. S. de.; VALADARES-INGLIS, M.C. (Ed.). Recursos genéticos e melhoramento plantas. Rondonópolis: Fundação MT, 2001. cap. 11 , p. 286-290.

VERDONCK, O. PENNINCK, R.; De DOODT, M. The physical properties as different horticultural substrates. Acta Horticulturae, n. 150, p. 155-160, 1983.

VIEIRA, L.G. A importância da bataticultura na região sudoeste para a economia brasileira. Batata Show, n. 2, p.9, 2001.

VIEIRA, M.L.C.; GLÓRIA, B.A. da. In: NASS, L. L.; VALOIS, A.C.C.; MELO, I.S.de, INGLIS, M.C.V.(Ed). Recursos genéticos \& melhoramento plantas, Rondonópolis: Fundação MT, 2001. p.913.

VITTI, G.C.; BOARETTO, A.E.; PENTEADO, S.R. Fertilizantes e fertirrigação. In: SIMPÓSIO BRASILEIRO SOBRE FERTILIZANTES FLUÍDOS. 1., Piracicaba, 1993. Anais. Piracicaba: POTAFÓS, 1994. p. 261-280.

YORINORI, G.T. Curva de crescimento e acúmulo de nutrientes pela cultura da batata CV. 'Atlantic'. Piracicaba, 2003. 66p. Dissertação (Mestrado) - Escola Superior de Agricultura "Luiz de Queiroz", Universidade de São Paulo. 
WATSON, D.J. The physiological basics of variation in yield. Advances in Agronomy, v. 4 , p. 101-144, 1952.

WESTERMANN, D.T.; KLEINKOPF, G.E. Nitrogen requirements of potatoes. Agronomy J ournal, v.77, p.616-621, 1985.

WESTON, L.A.; ZANDSTRA, B.H. Effect of root container size and location on growth and yield of tomato transplants. Journal of the American Society for Horticultural Science, v.111, n.4, p. 498-501, 1986.

WOLFE, D.W.; FERERES, E.; VOSS, R.E. Growth and yield of two potato cultivars to various levels of applied water. I rrigation Science, v. 3, p.211-222, 1983.

ZAAG, D.E. van der. A batata e o seu cultivo nos países baixos. Haia: NIVAA 1993. $76 p$.

ZORZELLA, C.A.; VENDRUSCOLO, J.L.S.; TREPTOW, R.O.; ALMEIDA, T.L. de. Caracterização física, química e sensorial de genótipos de batata processados na forma de chips. Brazilian J ournal of Food Technology, v. 6, p. 15-24, 2003. 